\title{
مواطن ( الاستخدام ) البديعي في القرآن الكريم جمعاً ودراسة
}

! I I

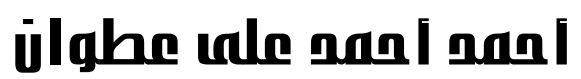

الأستاذ المساعد في قسهر البلاغت والنقد

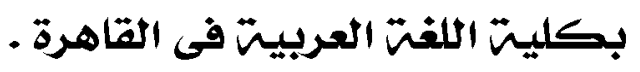


مواطن ( الاستخدام ) البديعي في القرآن الكريم جمعاً ودراسة ـــ 


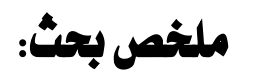

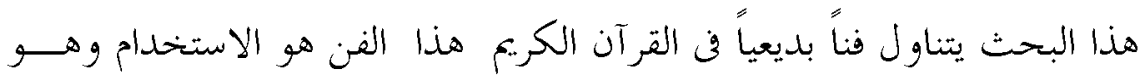

$$
\begin{aligned}
& \text { أن يذكر اللفظ .كعىن ويعاد عليه ضمير أو أكثر .كعىن آخر • وقد ذكر التـــداء أن }
\end{aligned}
$$

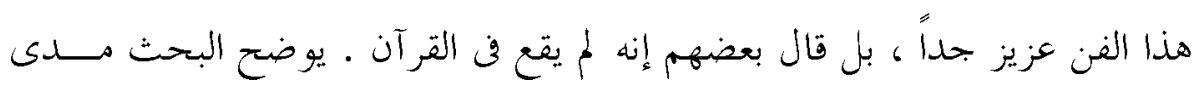

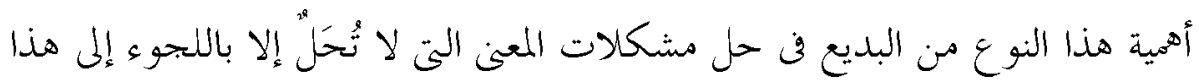

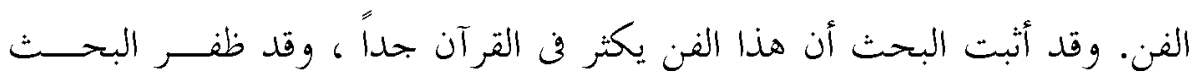

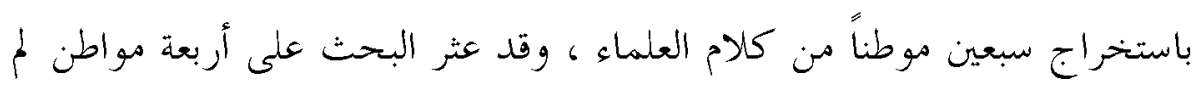

$$
\begin{aligned}
& \text { ينبه إليها أحد وقد جاء الاستخدام في تسع وأربعين سورة . وقتد لاحظ البحث أن } \\
& \text { الاستخدام يأتى في كل السور الطويلة منها والقصيرة ويدخل في جميع المعـان . }
\end{aligned}
$$

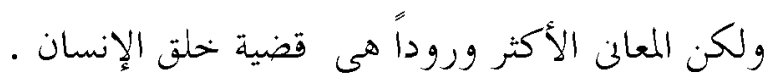

$$
\begin{aligned}
& \text { الكلمات المحورية :- } \\
& \text { ( استخدام - فن - البديع - الآية - الخلق - الإنسان ) }
\end{aligned}
$$

A summary

of the research of creative use in the Noble Qur'an

Prepared by: Ahmed Ahmed Ali Atwan - Assistant Professor in the Department of Rhetoric and Criticism at the Faculty of Arabic Language in Cairo.

This research deals with an original art in the Noble Qur'an. This art is used, which is to mention the word one meaning and repeat it with one or more pronouns in another meaning. The ancients mentioned that this art is very dear, and some even said that it did not fall into the Qur'an. The paper demonstrates the importance of this type of innovation in solving problems of meaning that can only be solved by resorting to this art. The research has proven that this art abounds in the Qur'an very much, and the research has succeeded in extracting seventy domains from the words of scholars. The research has found four citizens that no one has noticed, and the use came in forty-nine surahs. The research noticed that the usage comes in all the long and short surahs, and it enters in all meanings. But the meanings most mentioned are the issue of the creation of man.

Key Words: -

(Use - Art - Badia - Verse - Creation - Human). 
2010

الحمد لله والصلاة والسلام على سيدنا رسول الله و آله وصحبه ومن ولاه. ثمأم أما بعد

فهذا بحث يناول محسن الاستخدام البديعي في القرآن الكريم دعاني إلى دراسته ما ذكره بعض العلماء كأمثال الحمافظ السيوطي وغيره وهو أن هذا الخسبن عزيــز

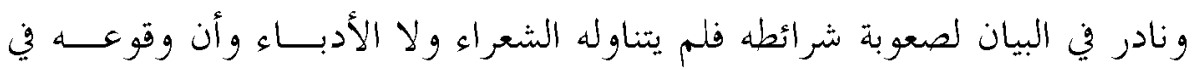
القرآن الكريم نادر • ومن ثم فقد صنعت هذا البحث خاصة أبي لم أجد من تناوله من قبل على قدر ما بحثت فجاء في مقدمة وتمهيد ومطلبين وخاتمة . أما المقدمة ففيها بيان الداعي إلى البحث والمنهج والخططة . وأما التمهيد ففيه تناول دراسة المصطلح تعريفا وتاريخا

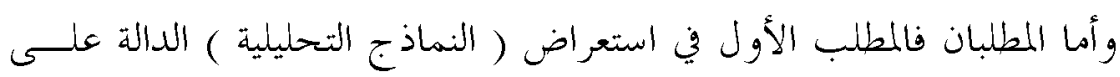
أهمية هذا الخسن في السياق والمقام و باغاغة الكلام . وأما المطلب الثاني ففيه عرض الآيات التي لم تدرس في النماذج التحليلية وبيان موطن الاستخدام وتوجيها وذكر من نص عليه أو أشار إليه في الهامش .

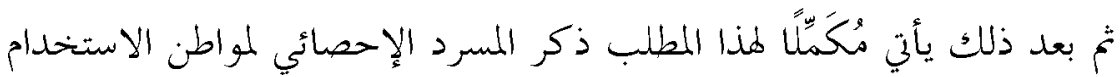

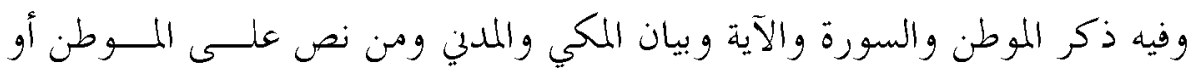
أشار إليه فيما يشبه الفهرس التحليلي . وقد اصطنع البحث المنهج الاستقرائي في تتبع المواطن مع المنهج التحليلي أثناء الدراسة و بعد ذلك تأتي الخاتمة وفيها أهم النتائج · 


\section{口التثمويل}

\section{الاستخدام في اللغة}

الاستخدام: من مادة ( خحََم)، وهذه المادة تتكون من ثلاثة حسـروف هــي:

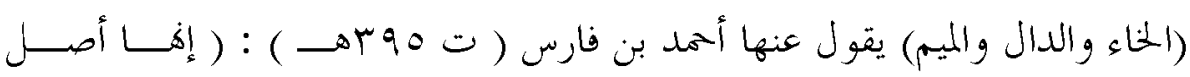
واحد مُنقَاس" وهو: إطافة الشيء بالشيء . يعني أن كل ما تفرع عنها من الألفاظ

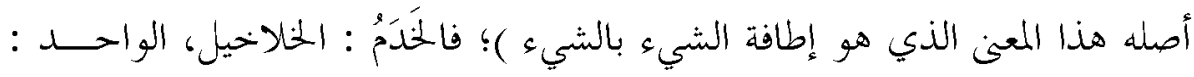

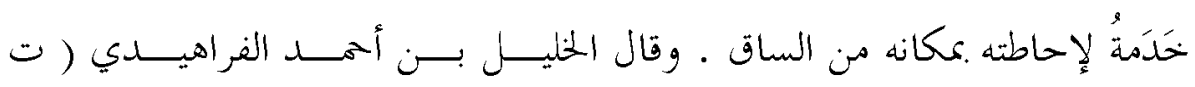

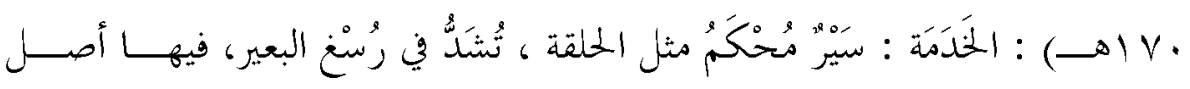

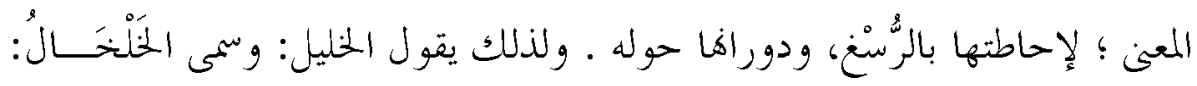

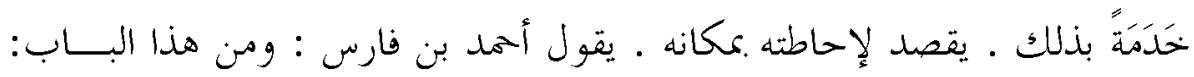

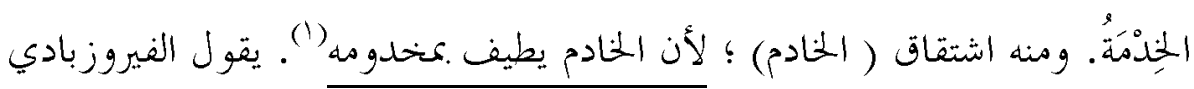

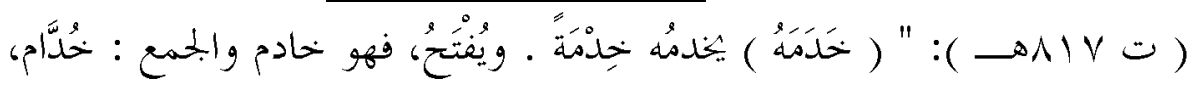

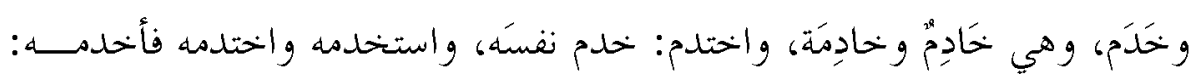

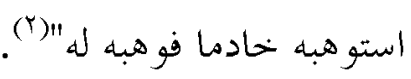
وعندما نستعرض تعريف الاستخدام بند العلاقة واضحة بن المعـين اللغــوي

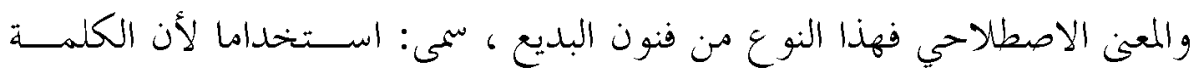

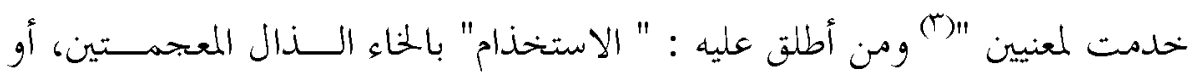

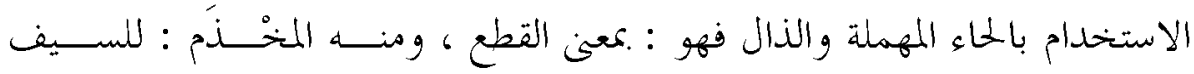

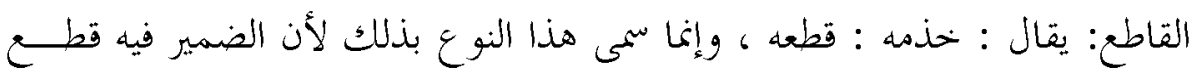

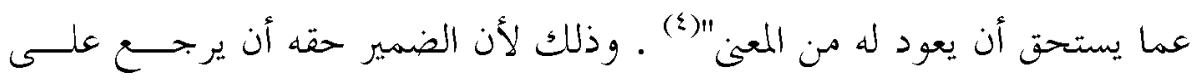

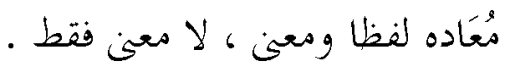

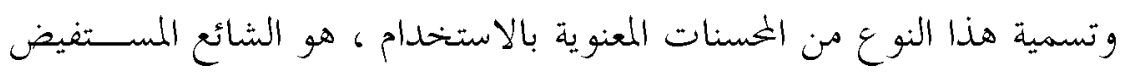
وهذا الاسم هو أول اسم وضع له عند أول من تكلم عنه، وهو أسامة بن منتــــد 


\section{مواطن ( الاستخدام ) البديعي في القرآن الكريم جمعاً ودراسة}

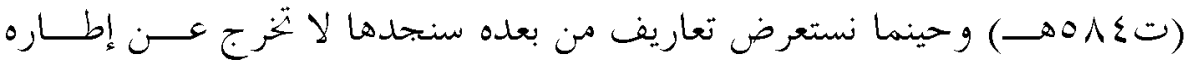

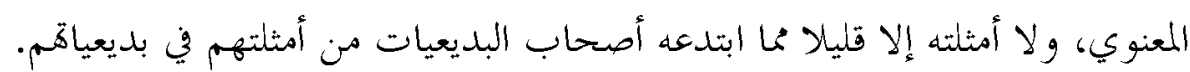

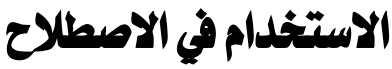

وبعد ان استعرض البحث المعنى اللغوي، وبين علاقته بالمعنى الاصطلاحي ،

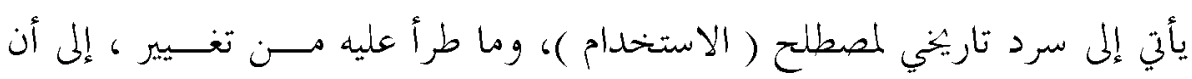
وصل إلينا عند متأخري البديعيِن:

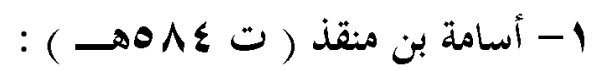

" اعلم أن الاستخدام هو أن تكون الكلمة لها معنيان، فتحتاج إليها فتذكرها

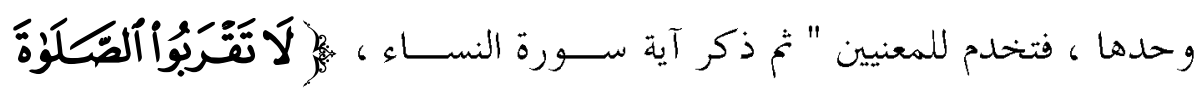

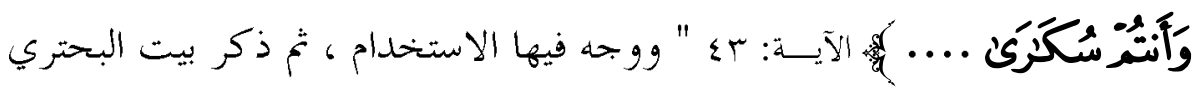

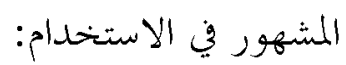

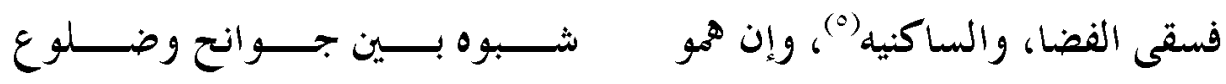

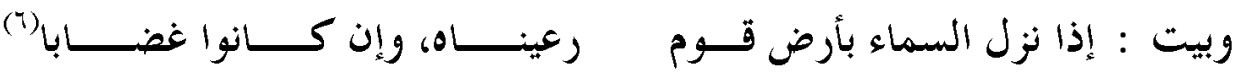

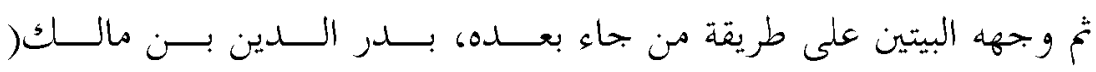

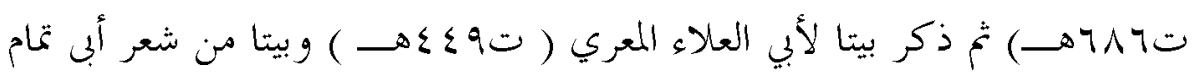

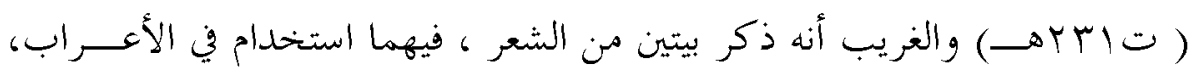
منا يدل على نضج هذا النوع من البديع عند أدباء هذا العصر.

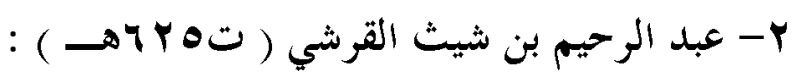

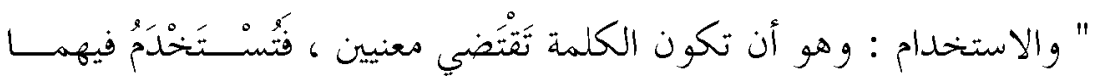

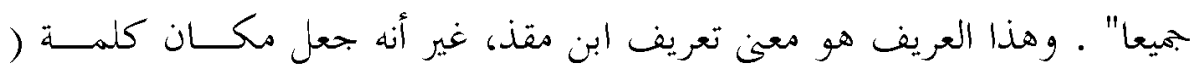

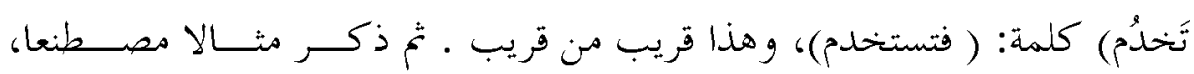
ووجهه، ثم ذكر بيت البحتري دون توجيه (A) . 


\section{مواطن ( الاستخدام ) البديعي في القرآن الكريم جمعاً ودراسة}

$$
\text { ب- عبد العظيم بن عبد الواحد، ابن أبي الأصبع(ت ع ه 7هـ) : }
$$

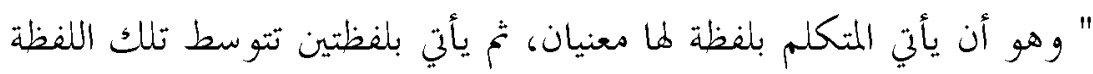

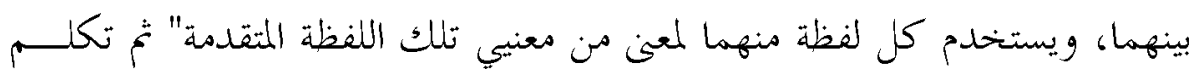
بعد ذلك عن الفرق بين التورية والاستخدام، ثم ذكر بيت البحتري، ووجهه توجيه

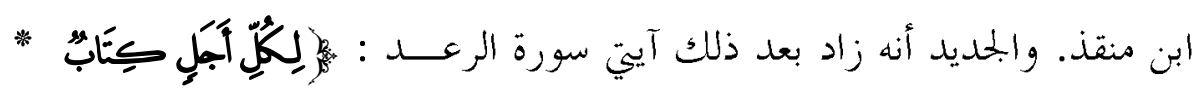

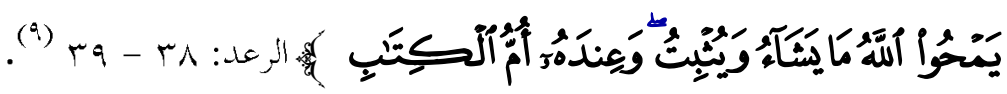

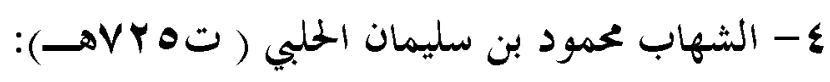

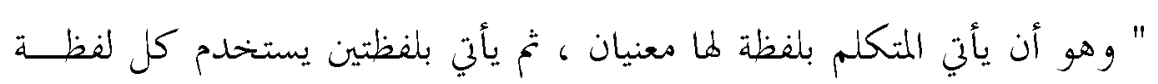

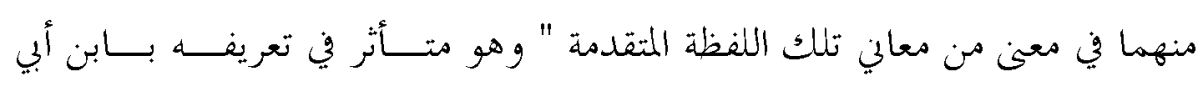
الأصبع وقد نقل كالامه في التغريق بين التورية والاستخدام، ثم ذكر أمثلة ابن منقذ

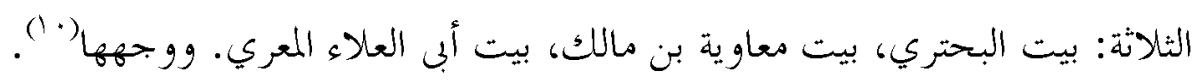

$$
\text { ه- محمد بن عبد الرحن، الخطيب الفزويني ( ت }
$$

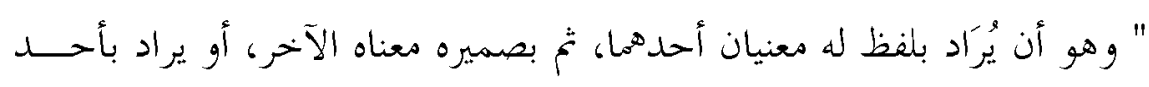

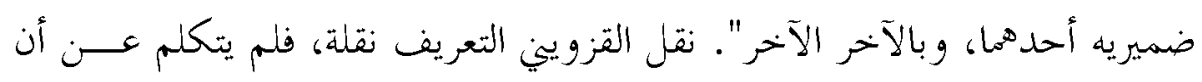

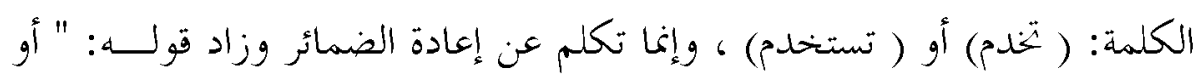

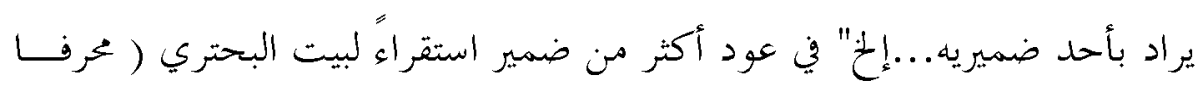

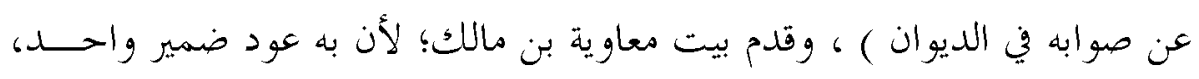

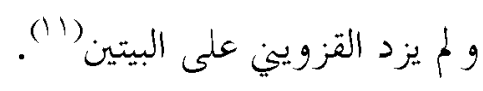

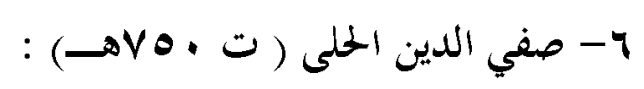

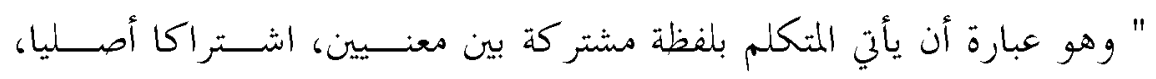

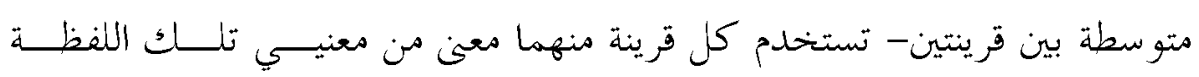

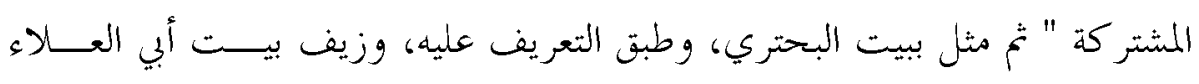


المعري، وبين أنه لا يصلح مثالا للاستخدام، ثم زاد الاستشهاد بآية بكع من سورة النساء، التي استشهد هـا ابن مقذ، و لم ينقلها عنه أحد بعد سوى الحلى (rا').

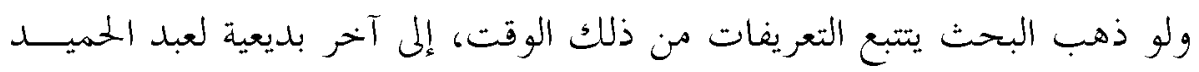

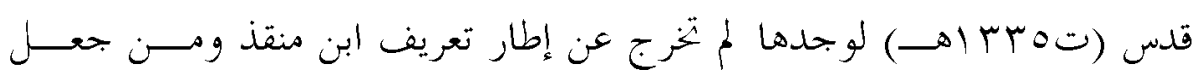

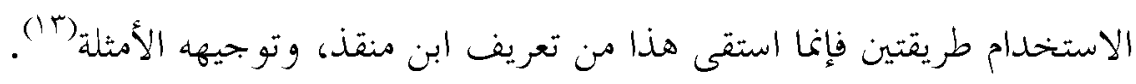

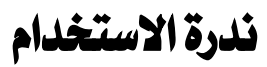

بقى أن يشير البحث إلى أن الصفي الحلى قد تكلم عن ندرة هذا النوع فتــال: " وهذا نوع عزيز الوقوع ، معتاص على الناطم، شديد الالتباس بالتورية. قلما تكلفه

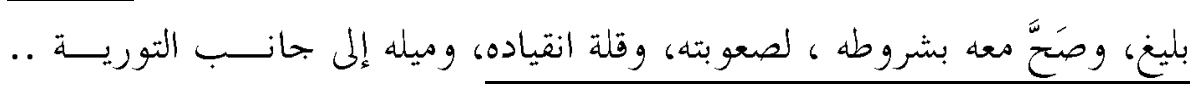

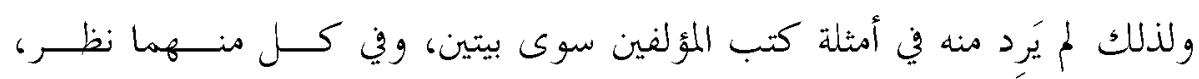

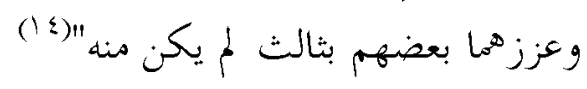

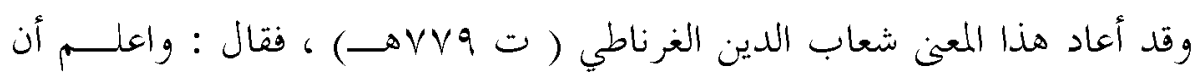

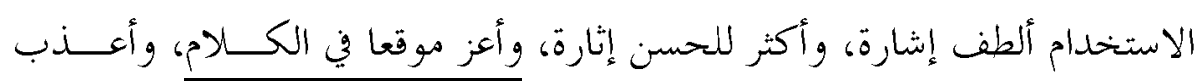

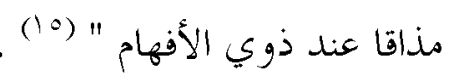
الاطلب الأول( النماذج القحليلية ) : بيان ثواب المؤمنين

$$
\text { (Y) سورة البقرة }
$$

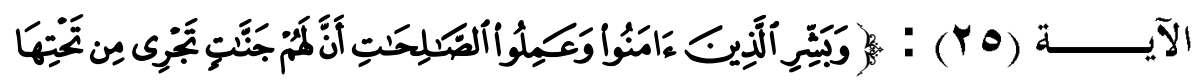

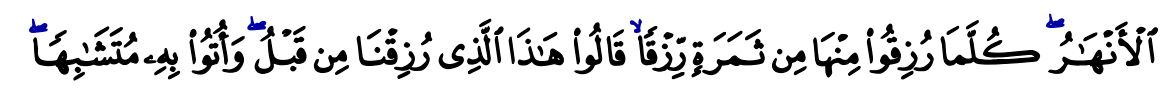

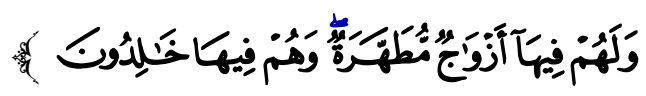

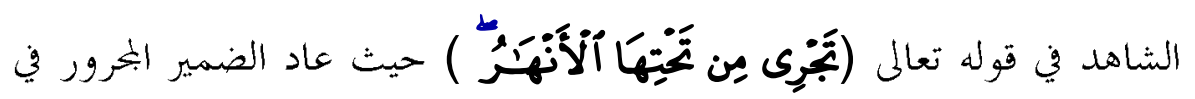

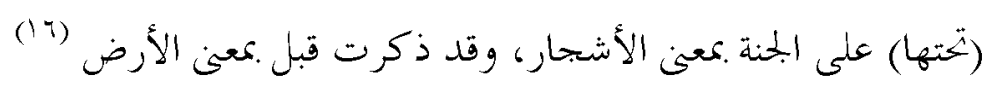
التحليل البالاغي: (iv) بيان السياق :"لا كان من عادة المولى عز وجل في كتابه أن يذكر الترغيب مع 


\section{مواطن ( الاستخدام ) البديعي في القرآن الكريم جمعاً ودراسة}

الترهيب ويشفع البشارة بالإنذار، إرادة التنشيط لاكتساب ما يزلف والتثبيط عن اقتراف ما يتلف، لَّا ذكر الكفار وأعمالهم وأوعدهم بالعقاب، قفَّاه ببشارة عباده الذين جمعوا بين التصديق والأعمال الصالحة، من فعل الطاعات وترك المعاصي ..

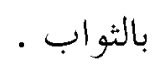

من اللطائف البلاغية : إبهام المخاطب المأمور في قوله عز وجل :

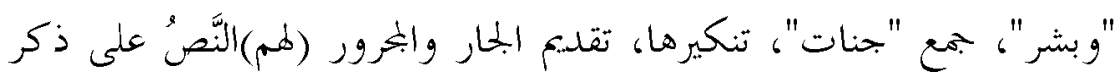

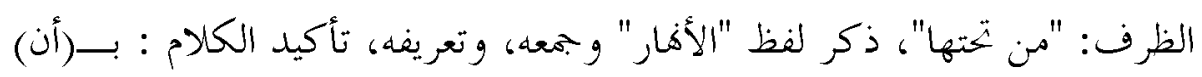
في(أن لهم جنات)، التعبير بالمضارع: (بتري)، بيان المخاز العقلي في (تَّْرِى مِن

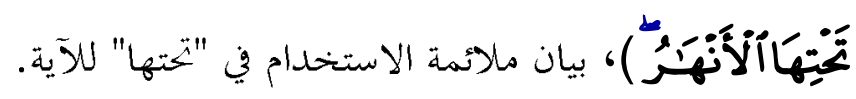

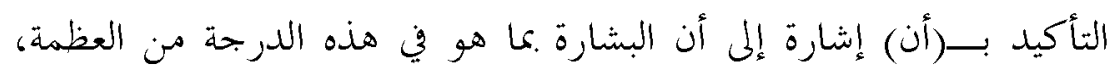

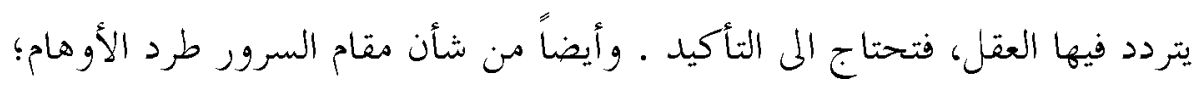

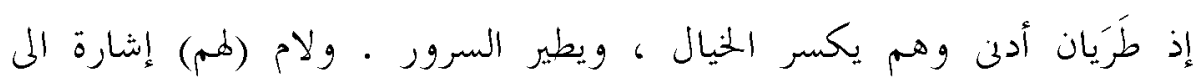

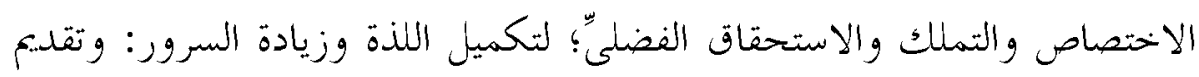

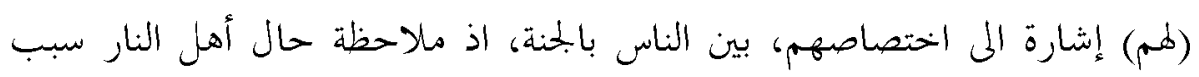

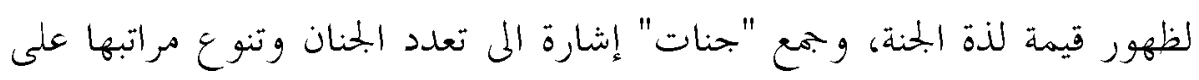
نسبة تنوع مراتب الاعمال، و كذا رمز الم أن كل جزء من الجنة جنة... و كذا إيماء إلى أن ما يصيب حصة كل - لو سعته - كأنه - كالجنة بتمامها، لا كأنه يساق بجماعتهم الم موضع وتنكير "جنات" يتلو على ذهن السامع : " فيها ما لا عين

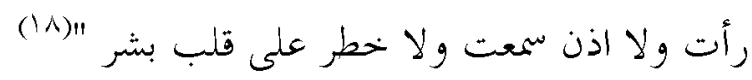

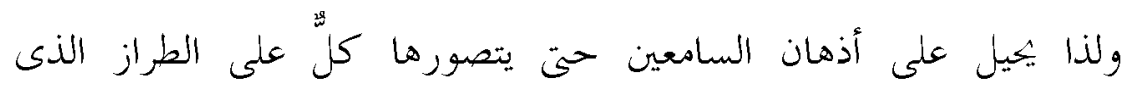

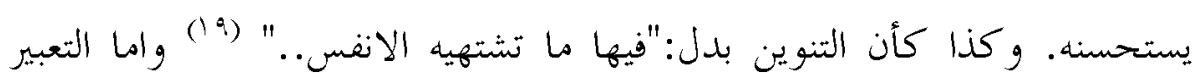
بالمضارع. "بخرى" فأعلم أن أحسن الرياض ما فيها ماء. ثم أحسنها ما يسيل ماؤها، ثم أحسنها ما استمر السيلان، فبلفظ تبرى أشار إلى تصوير دوام الجريان: 
وأما "من تحتها " فاعلم: أن أحسن الماء الجاري في الخضروات أن ينبع صافيا من

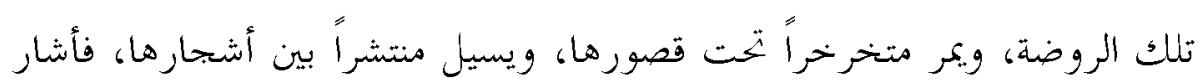

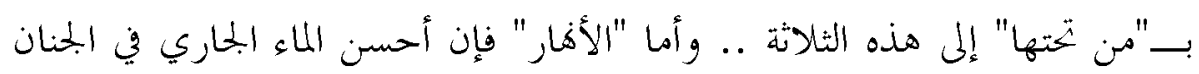

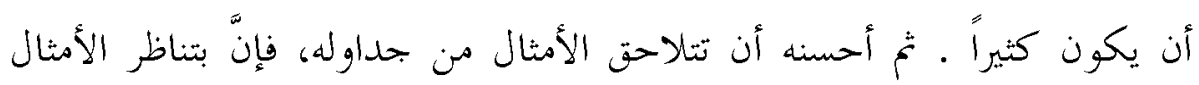

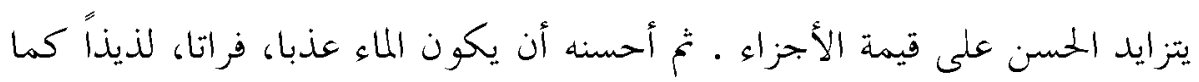

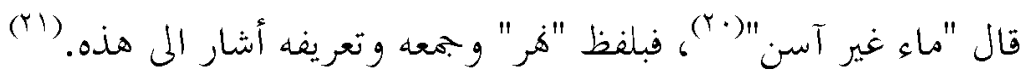

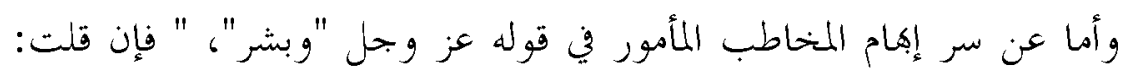
من المأمور بقوله تعالى :(وبشر)؟، قلت : يبهز أن يكون رسول اللّ صلى الله عليه وسلم، وأن يكون كل أحد كما قال عليه الصلاة والسلام: "بشر المشائين إلى

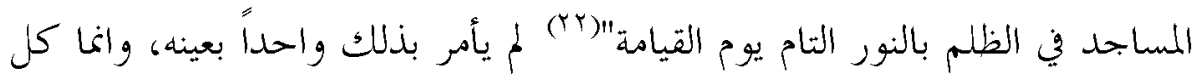
أحد مأمور به، وهذا الوجه أحسن وأجزل؛ لأنه يؤذن بأن الأمر لعظمه، وفخامة

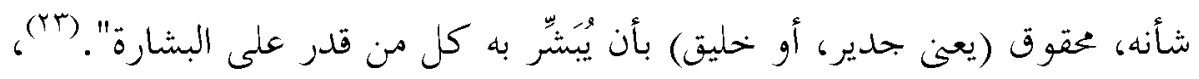

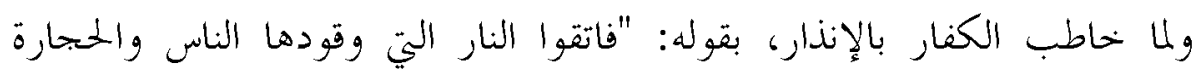

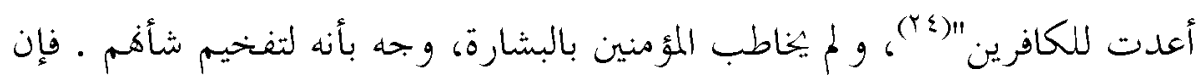
من حدث له ما يسره، قد ينادى لإعلامه، وقد يرسل اليه الخخبر، والثاني فيه تعظيم

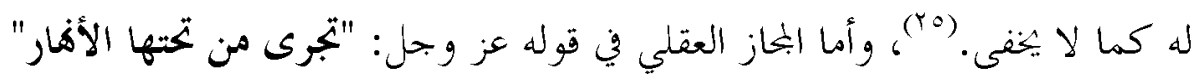

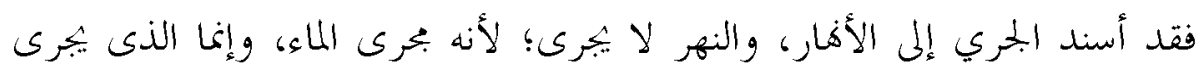

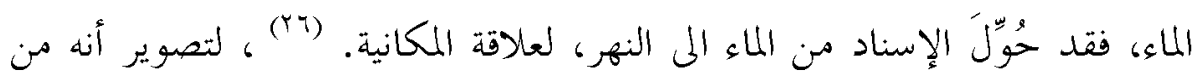

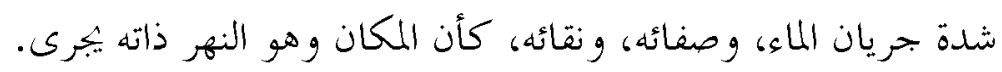

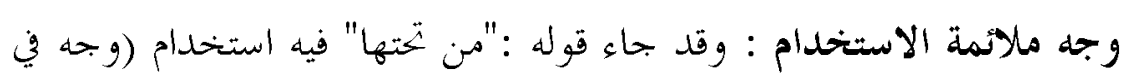
صدر الكالام)؛ لأن الاستخدام من أهم خصائصه الإيباز لأنه يغني عن ذكر: "تجرى من تحت أشجارها الأكار" والإيباز فيه جزالة وفخامة تناسب المحاز العقلي الذى يتسم أيضاً بالإيجاز والمبالغة . 


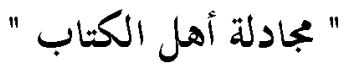

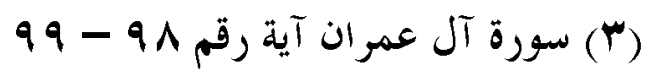

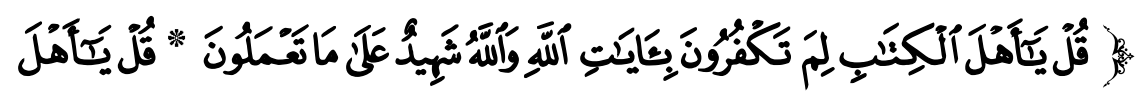

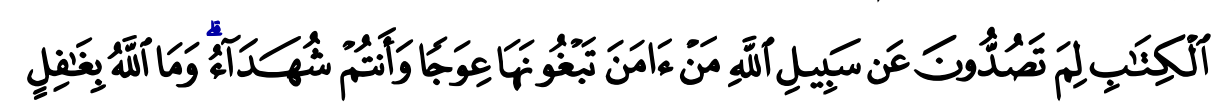

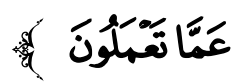

التحليل البلاغي : السياق: " هذا ابتداء كلام رجع به إلى بحادلة أهل الكتـــاب ،

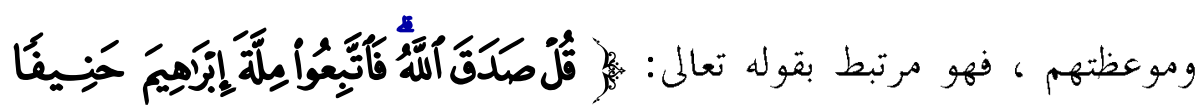

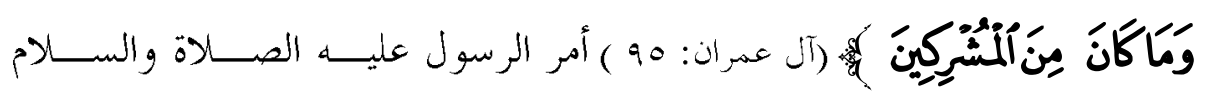

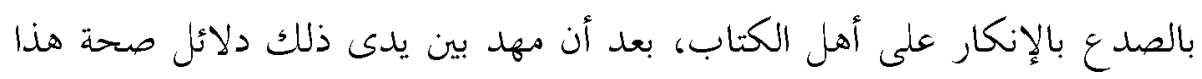
الدين "(VV)" ـ اللطائف البلاغية : الإتيان بأسلوب الإنشاء ، الأمر : " قل " ، النداء

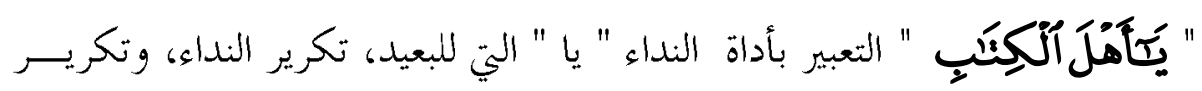

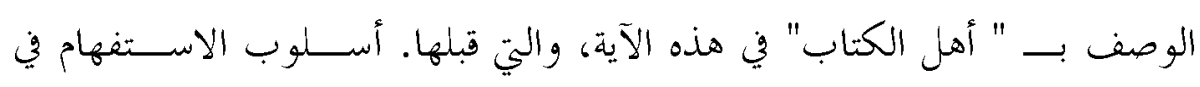

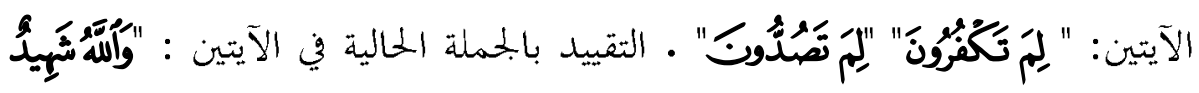

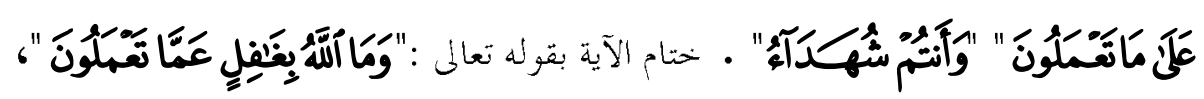
بيان ملاعمة الاستخدام لبلاغة الآية . ابتدأ الخطاب بأسلوب الأمر "قُل" لبيان الاهتمام بالمقول. ثم افتـتحتح المقـــول بنداء أهل الكتاب، بـــ" يا " حرف النداء الذي هو للبعيد إشارة إلى بعدهم عــن

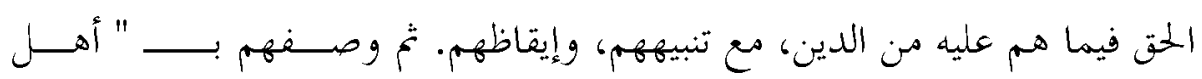
الكتاب" وكرر الوصف في الآيتين للتسجيل عليهم: كيف أهم أهــل كتـــاب ،

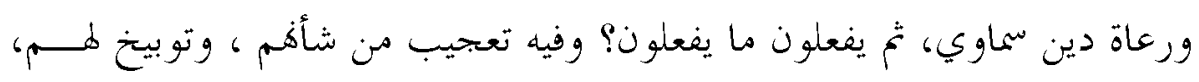

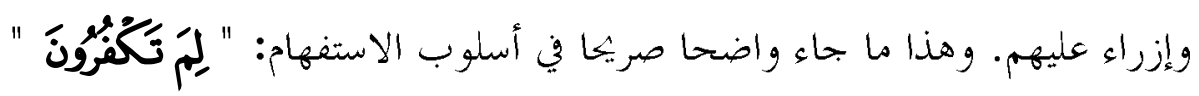

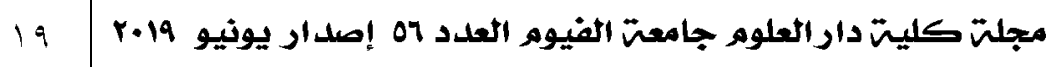




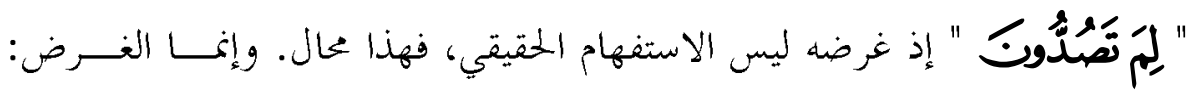
الإنكار عليهم وتوبيخيهم، يعني: ما كان ينبغي لكم أن تفعلوا ذلك، وأنتم أهـل

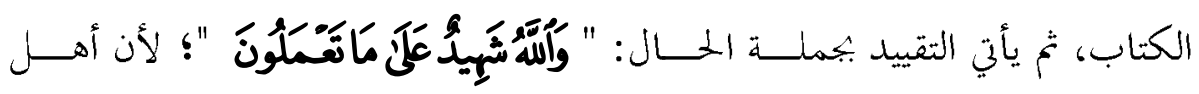

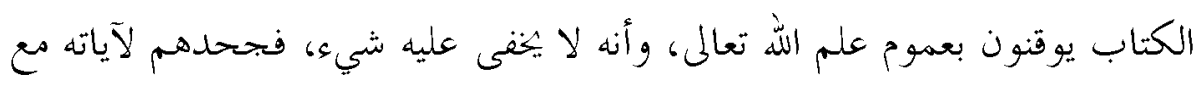

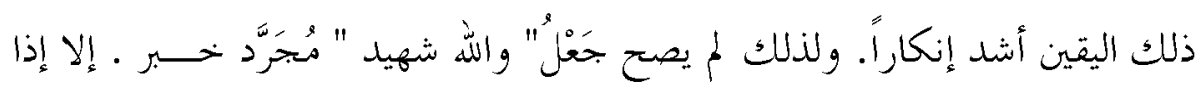

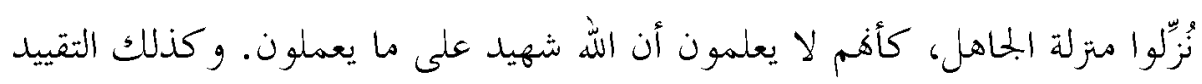

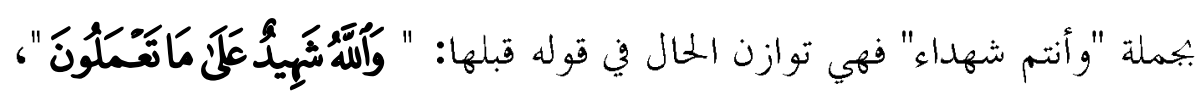

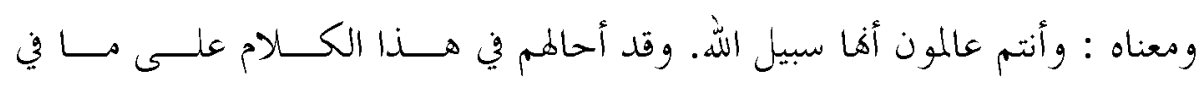

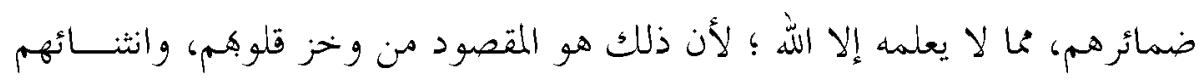

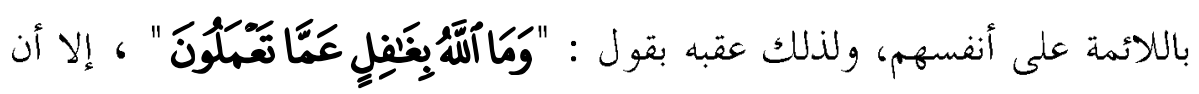

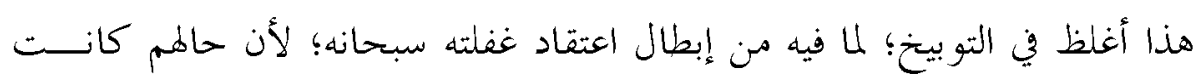

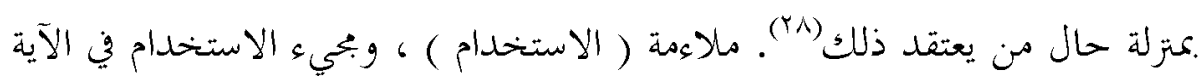

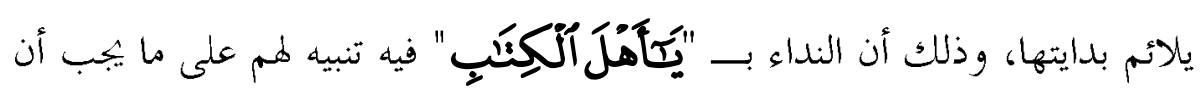

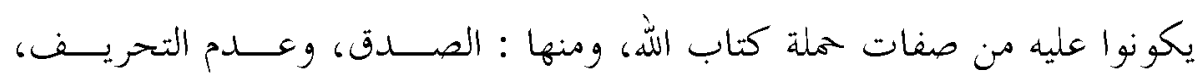
واستقبال الحق بالحق. وفيه أيضا ملاينة وتوقير لهم، وقد عاد الضمير في قولــه: "

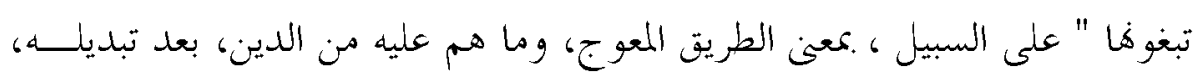

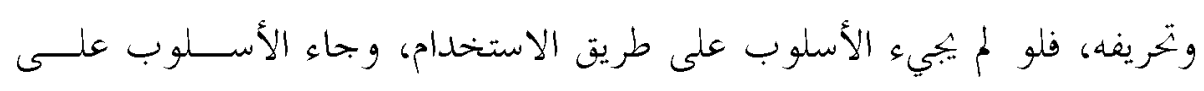

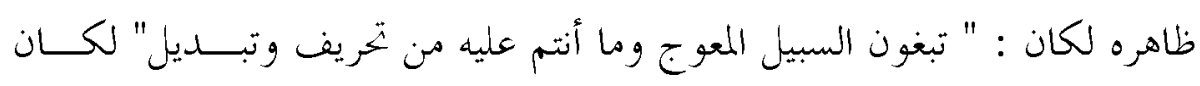
الكالام كفاحًا لهم، ومواجهة تستثيرهم وتحرضهم على المعاندة. ولذلك فقد كــان

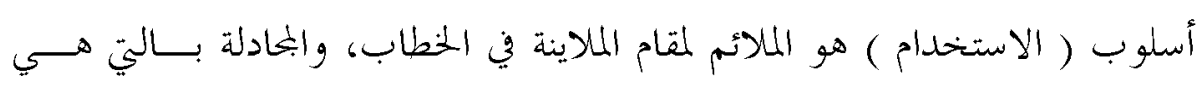
أحسن • مع الإيجاز المفاد من التعبير بالضمير. 


\section{" عصمة الأنبياء = الاستخدام ضرورة تأويلية"

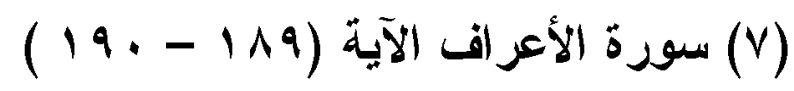

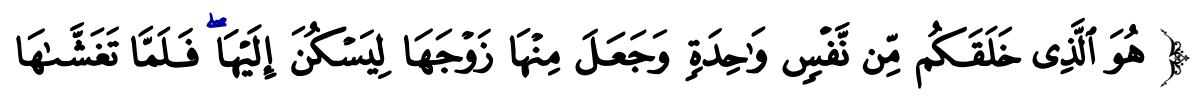

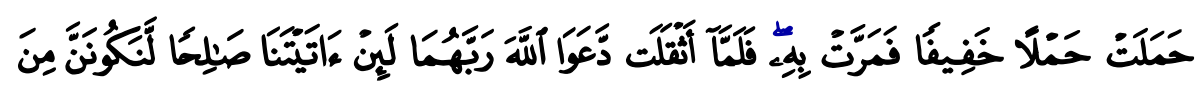

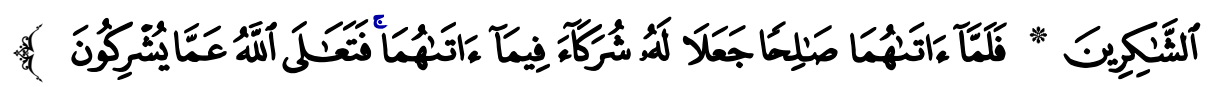

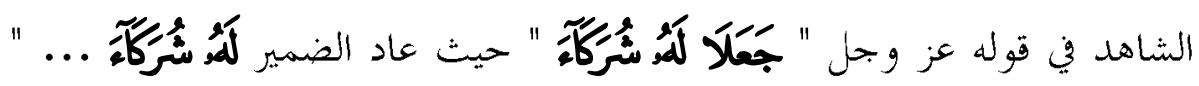

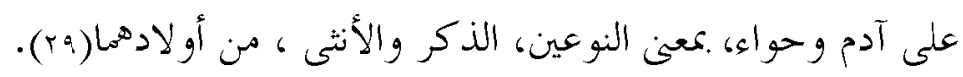
السياق : استئناف كالام لبيان ما يقتضى التوحيد، الذي هو المقصد الأعظم. من اللطائف البلاغية: التعبير عن المسند بالموصولية في قوله عز وجــل :" هُوَألَّنِى

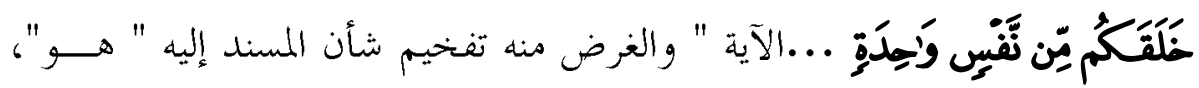

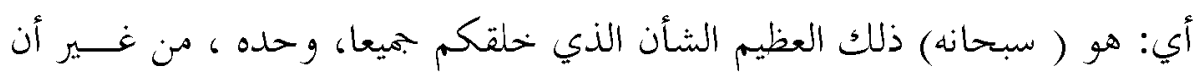

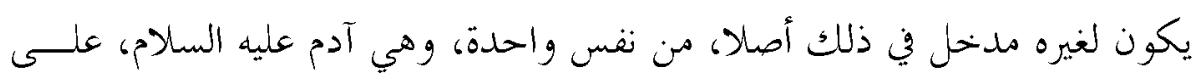

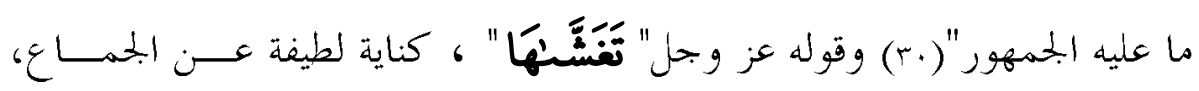
ثناسب مقام الحديث عن مقام النبوة، وكذلك قوله عز وجل : ليسكن" . أما قوله " أَثْتَلتَ " ففيه إشارة إلى دنو وقت الولادة وفيه إيماز، والعطف بالفاء في قولــه:

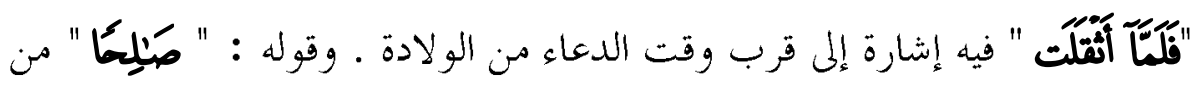
الإيباز أيضا، وفيه إفادة عموم معاني الصلاح . " فالصلاح قد يشمل معاني كثيرة:

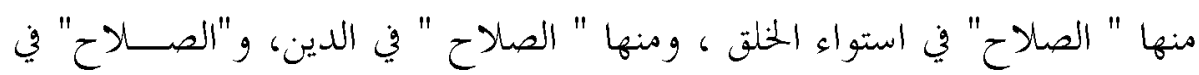
العقل والتدبير. وإذا كان ذلك كذلك ، ولا خبر عن الرسول يوجب الحجة بــأن ذلك ( أي الصلاح) على بعض معاني " الصلاح" دون بعض، ولا فيه من العقــل

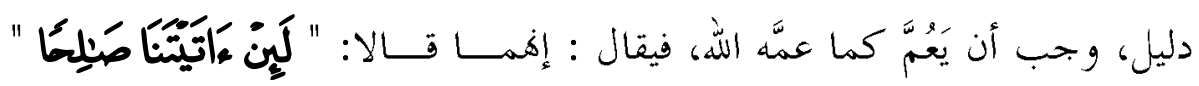


بجميع معاني الصلاح (آ)" . ثم يأتي الالتفات من الخطاب في قوله عـز وجهـل "

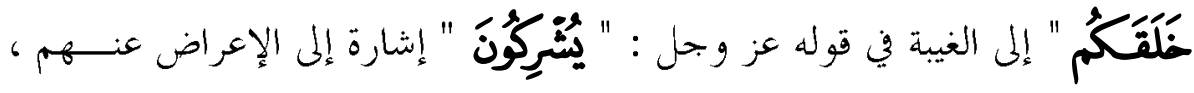
والإزراء همم ، فليسوا أهلا للخطاب، والمقصود بكذا هم كفار قريش، ففيه تعريض هـم(rr) ـ أما جمع الضمير في قوله :" يُشَرِكُونَ " فيفه دليل على إرادة النوعين من

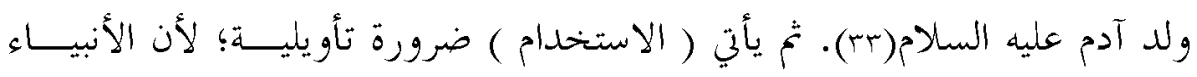

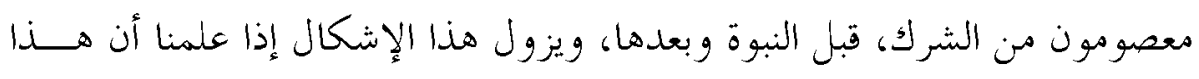

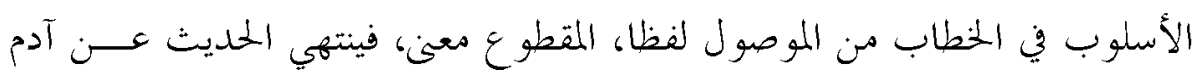
وحواء ( عليهما السلام ) عند قوله : " دَعَوَا آلََّّرَبَهُمَا " وباقي النص في غيرها

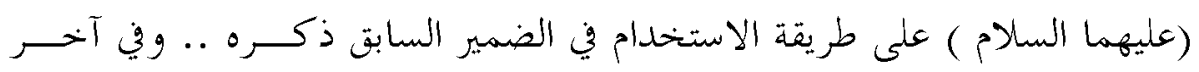

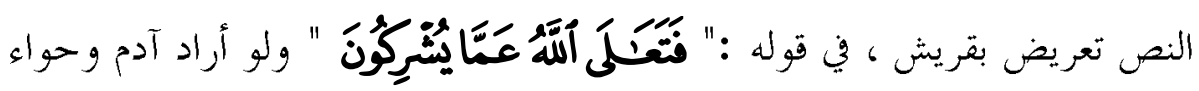

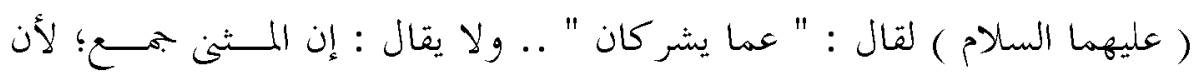
القرينة العقلية والنقلية تبطل إرادة المثنى هنا ، والقرينة هي العصمة الثابتة بالعقــل

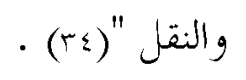 \\ الاطلب الثثاني : عرض آيات الاستخدام وتوجيهها (1)}

\section{ا ـ سم الله الرحمن الرحيم.}

"وفيها الاستخدام بناء على أن المراد من اسم الجلالة اللفظ، وفي "الرحمن"

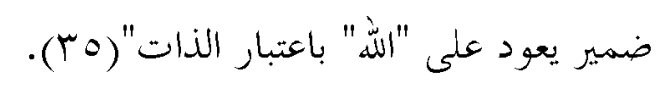

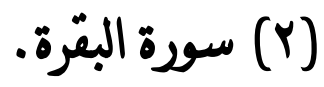

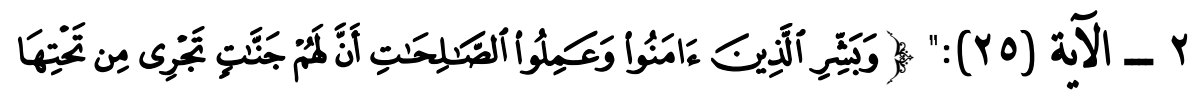




\section{مواطن ( الاستخدام ) البديعي في القرآن الكريم جمعاً ودراسة}

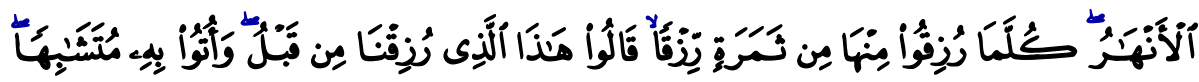

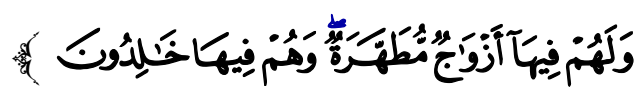

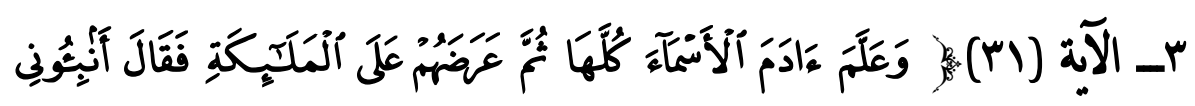

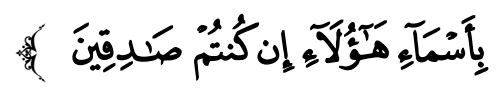

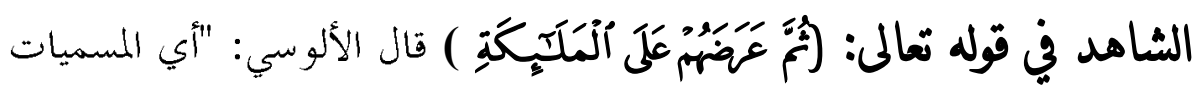

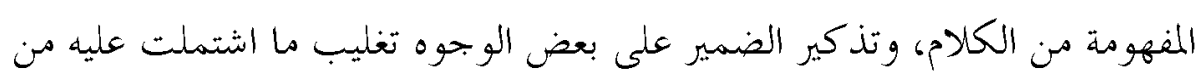

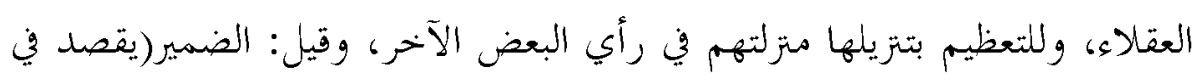

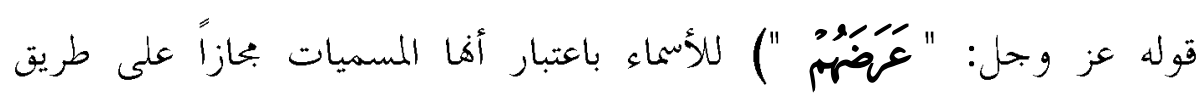

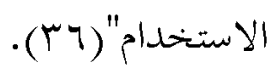

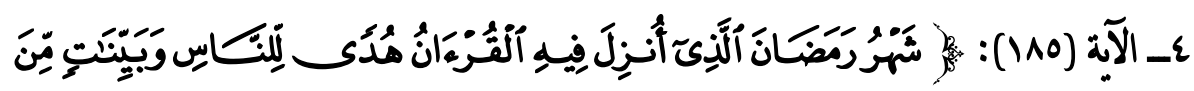

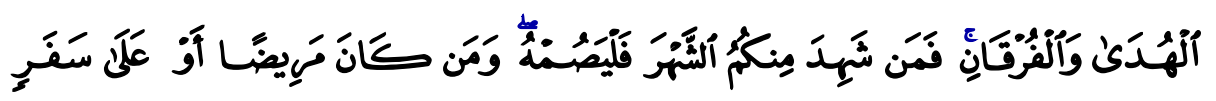

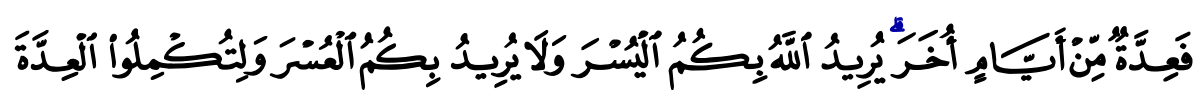

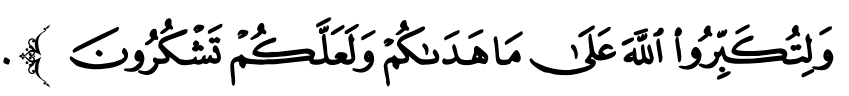

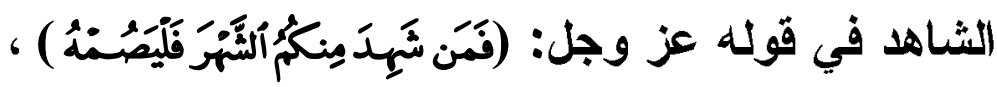

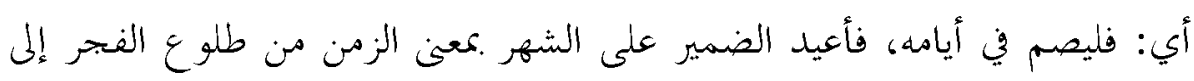

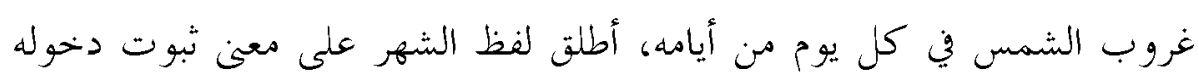

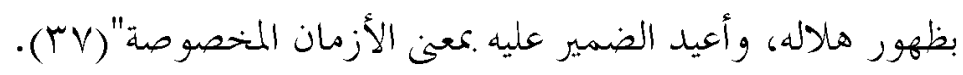

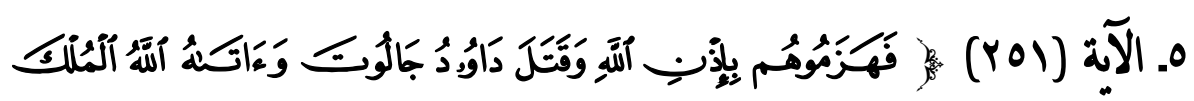

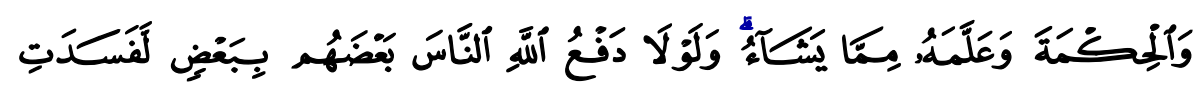




\section{مواطن ( الاستخدام ) البديعي في القرآن الكريم جمعاً ودراسة}

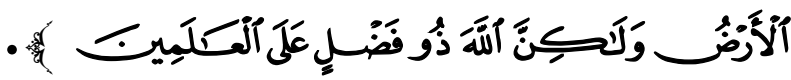

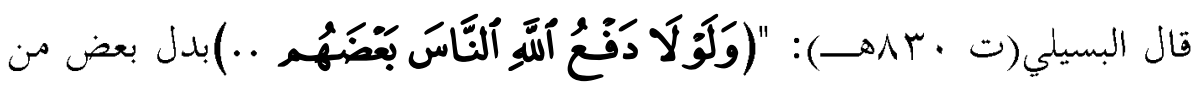
كل، و لم يقل: ولولا دفع الله بعض الناس ببعض؛ ليفيد أن المدفوع أكثر، قاله

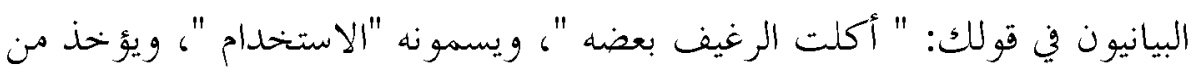

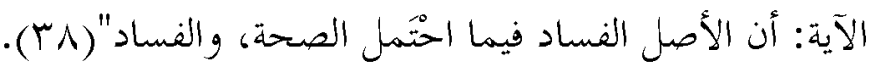

T_ الآلَة (YVI)

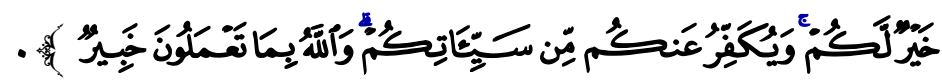

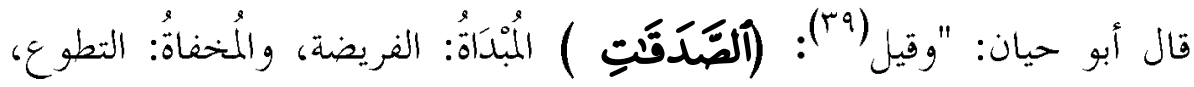

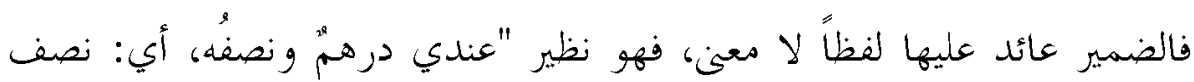
درهم آخر، كذلك: "وَإِن تُخْفُوهَا "، تقديره: وإن تخفوا الصدقات غير الأولى، وهي صدقة التطوع، وهذا خحاف الظاهر، والأكثر في لسان العرب"( •ع). علق الإمام البسيلي على كلام أبي حيان قائلاً: "أراد أن الصدقات غير الثرات الثانية؛ لأن

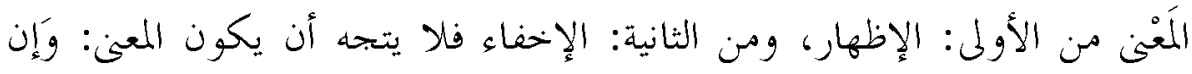
تخفوا الصدقات المظهرة. ونظير ذلك "عندي درهم، ونصفة" قد يفرق بينهما بأن الدرهم متشخص فلهذا

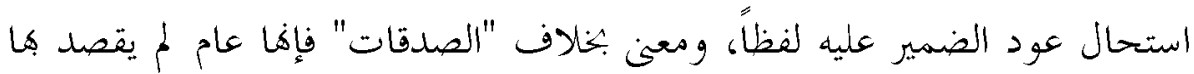
صدقة معينة، وجعل بعضهم: "عندي درْهِم ونصفة" من باب الاستخدام" (اع).

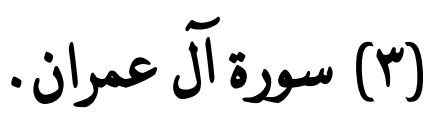

V_الآلَّان (

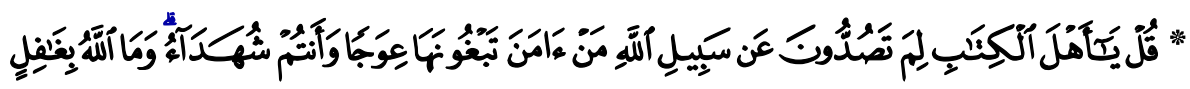




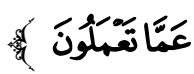

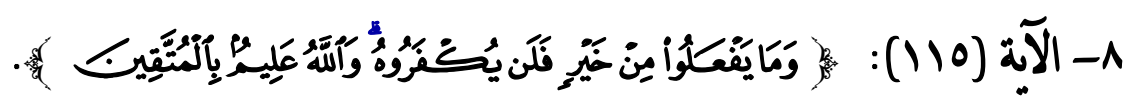

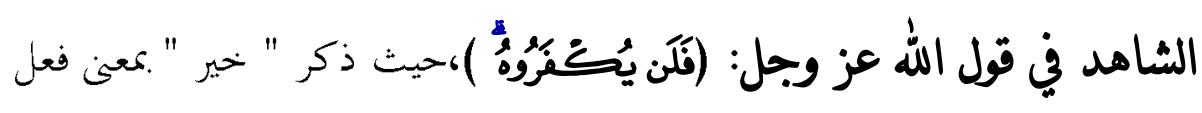

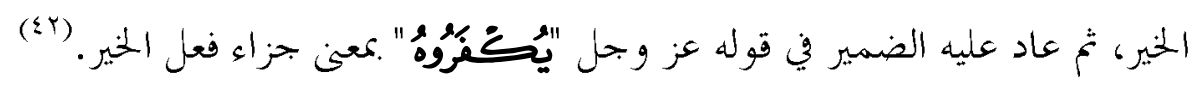

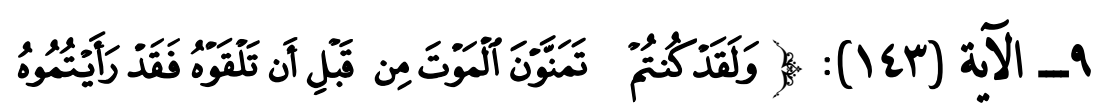

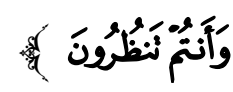
الشاهد في قول الله عز وجل: (فَعَدَرَآَيَتُمُوهُ)، قال (ابن عاشور : "ويحتمل أن يكون قوله: (تمنون الموت) معمني تتمنون موت الشهادة في سبيل الله، فقد رأيتم

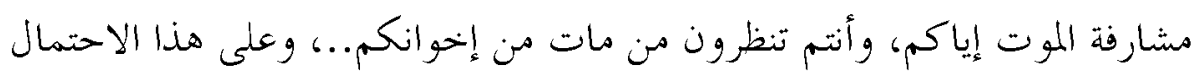

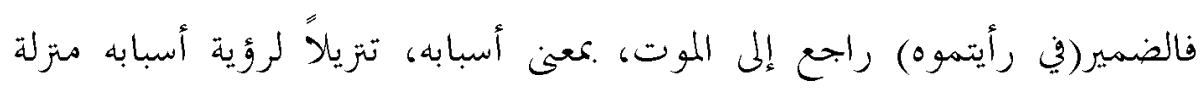

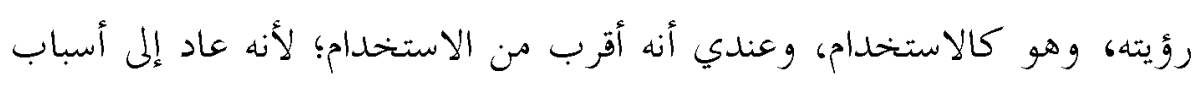

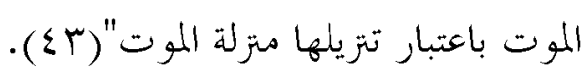

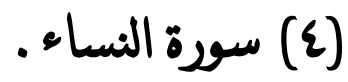

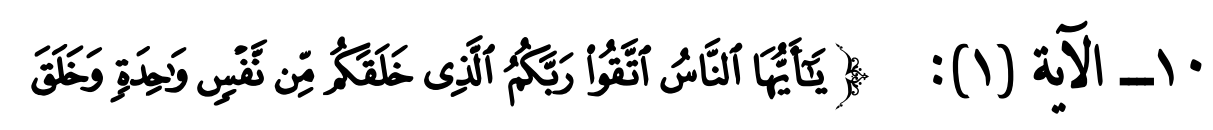

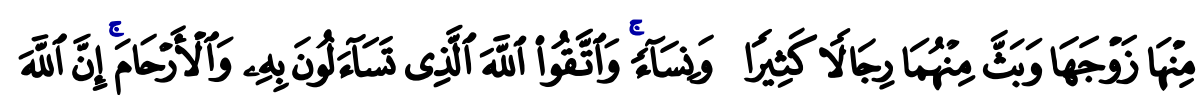

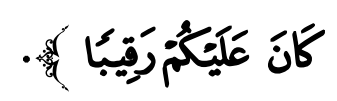

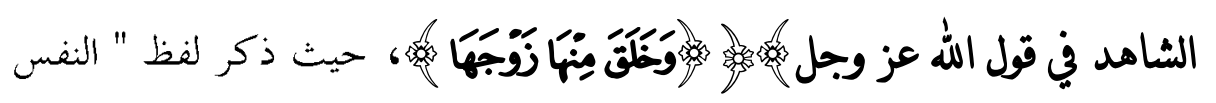

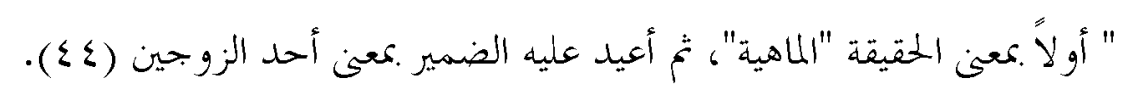

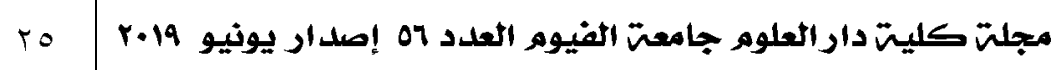




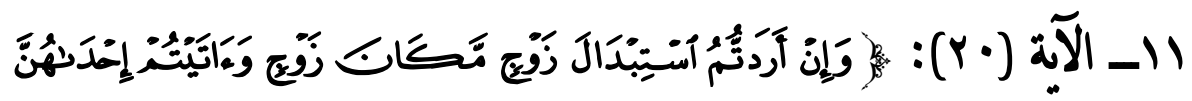

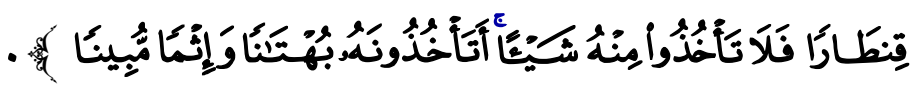

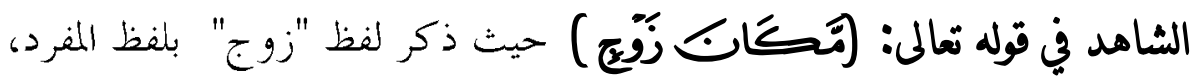

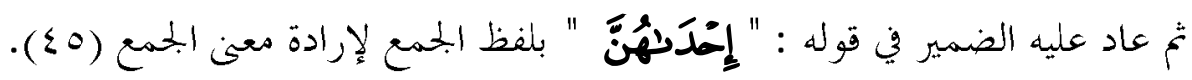

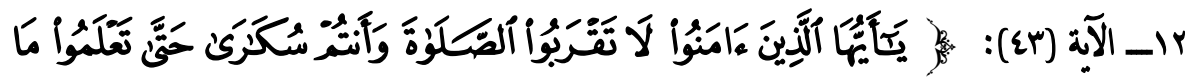

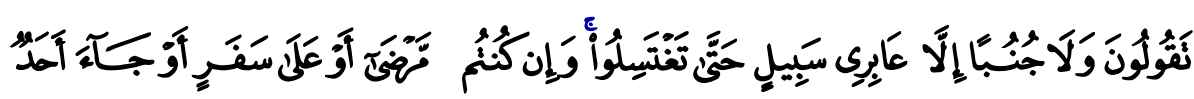

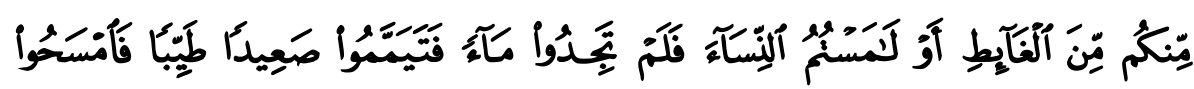

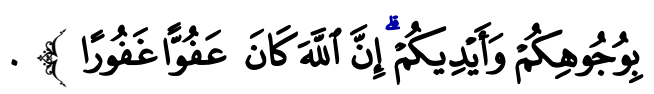

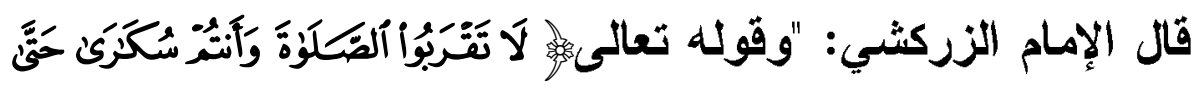

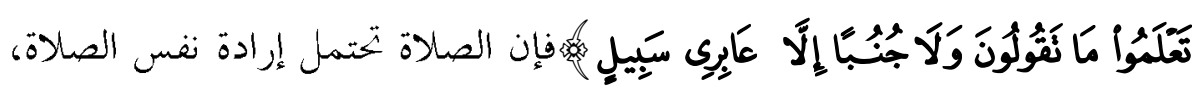

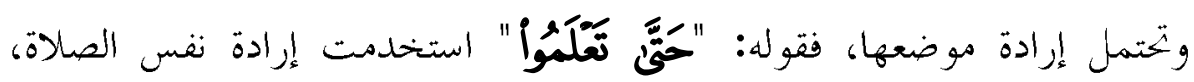

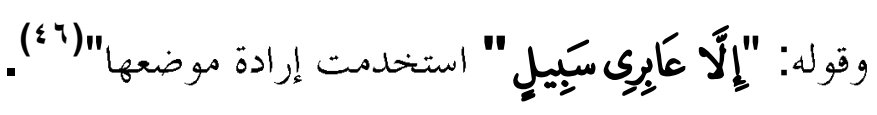

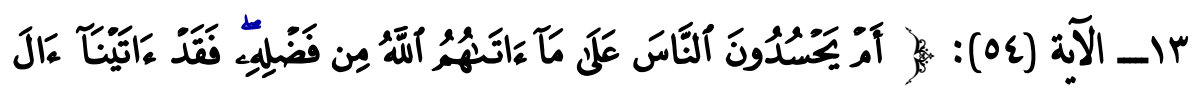

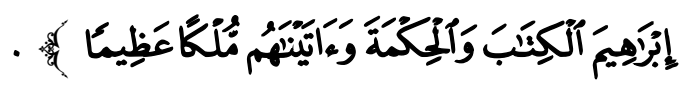

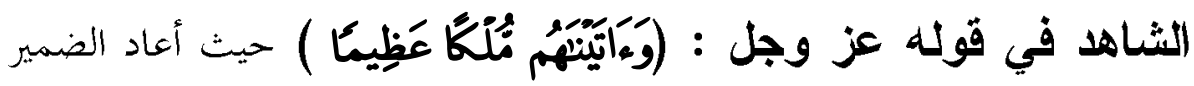

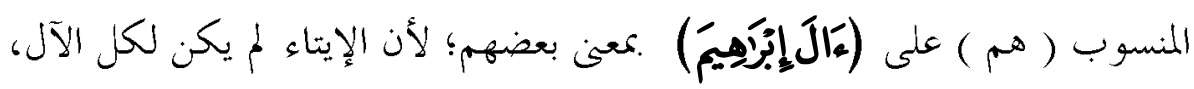

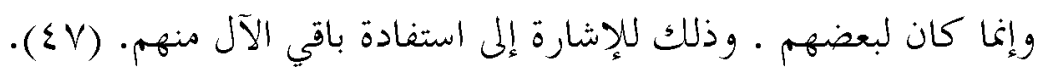

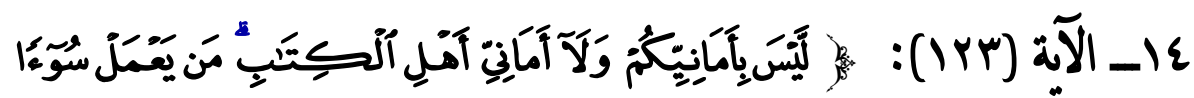

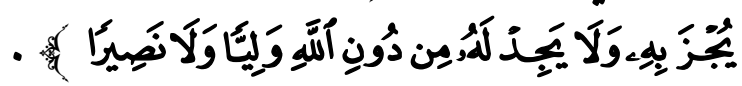




\section{ـــــــ مواطن ( الاستخدام ) البديعي في القرآن الكريم جمعاً ودراسة}

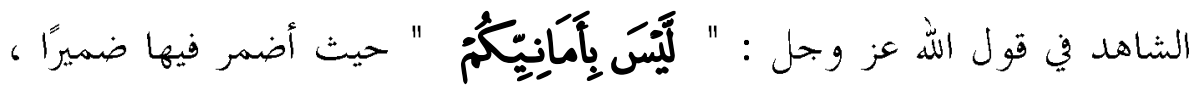

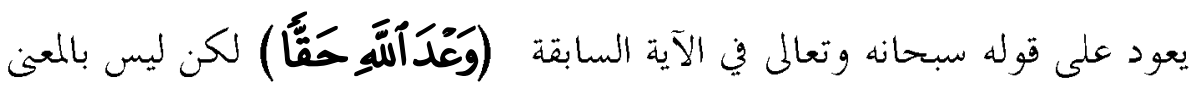
المصدري، الذي هو (وعد ) وإنما بمعنى ( موعود الله ) وهو ثواب العمل الصالخ) (

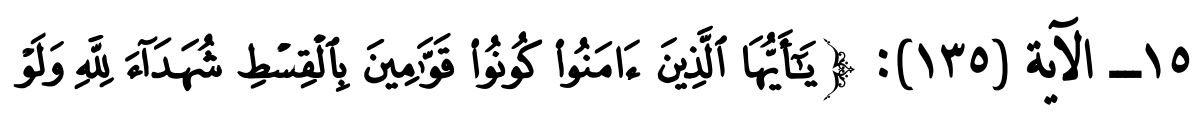

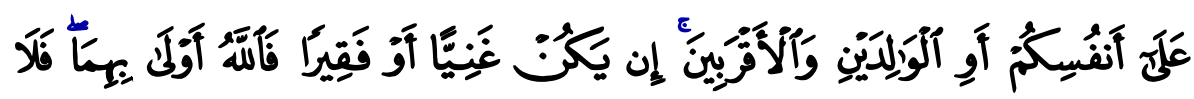

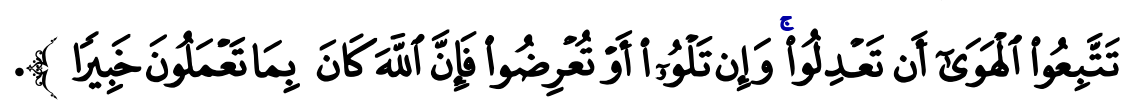

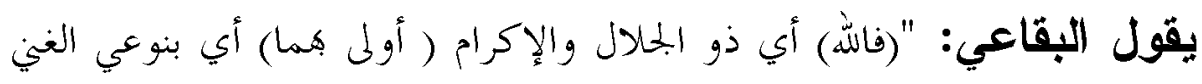

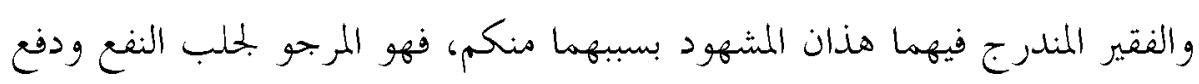

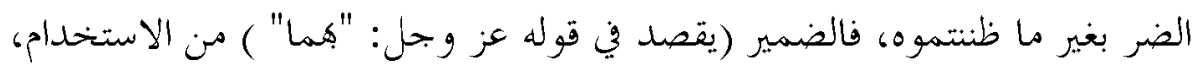

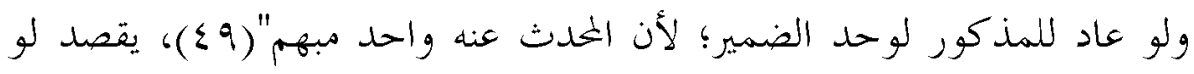

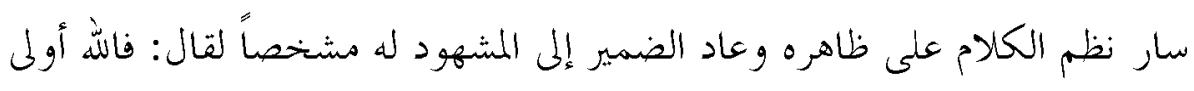

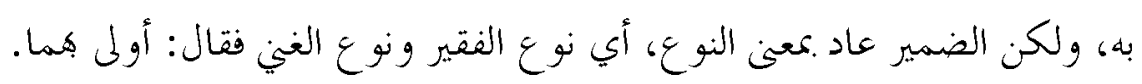

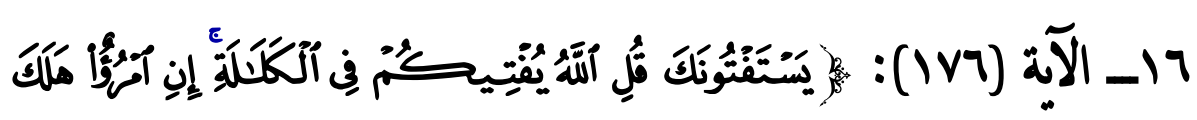

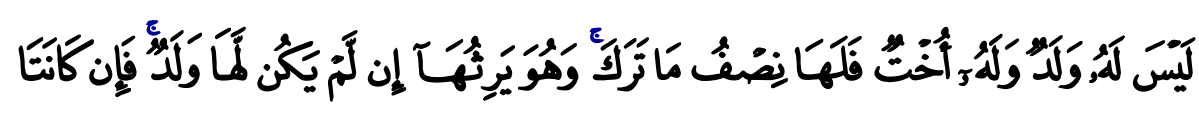

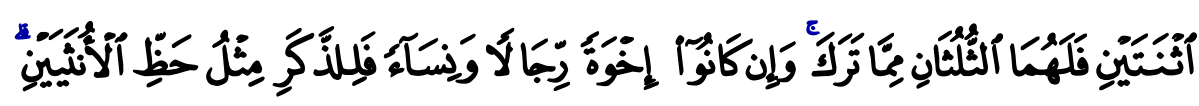

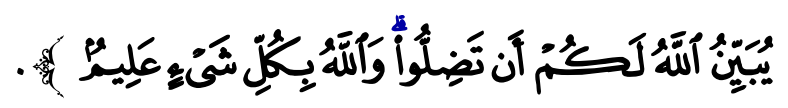
قال العلامة الصاوي (ت إي اههـ): "قوله (وهو) الضمير عائد على لفظ (امرؤ)

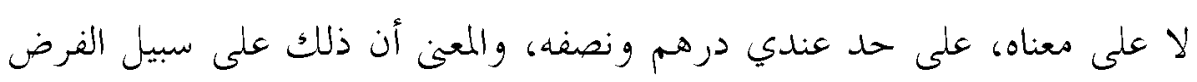
والتقدير، أي إن فرض موته دوها فلها النصف وإن فرض موها دونه فله المال كله 
إن لم يكن لها فرع وارث"( •())، حينما نقول: "عندي درهم و نصفه" لا نقصد أن

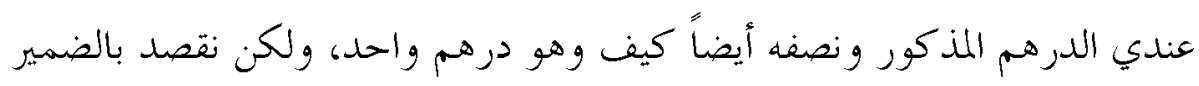
في نصفه لفظ الدرهم مععن الجنس، أي ونصف درهم آخر، فهذا من الاستخدام كما مر قبل ذلك.

\section{(0) - (0) سورة المائدة.}

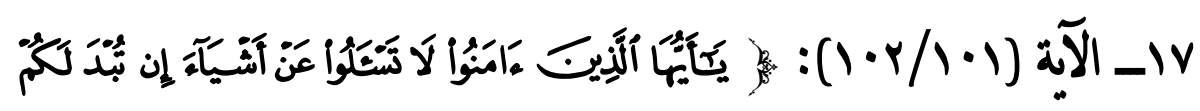

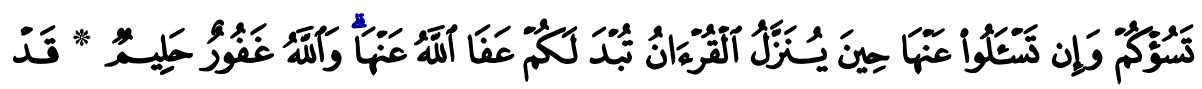

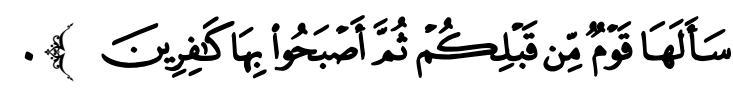

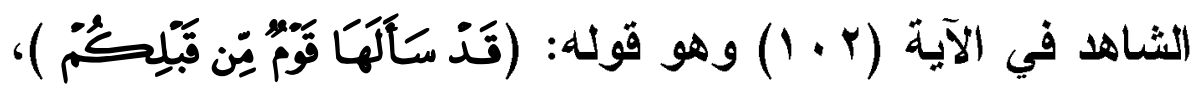

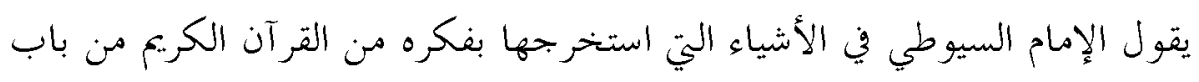

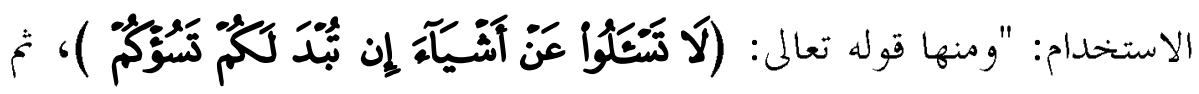

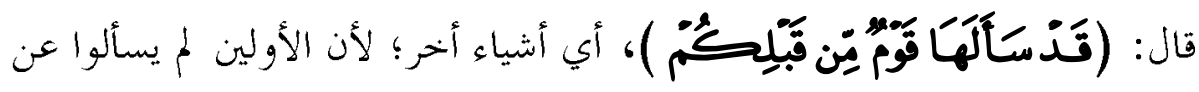

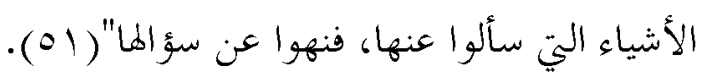

\section{(7) سورة الأنعام.}

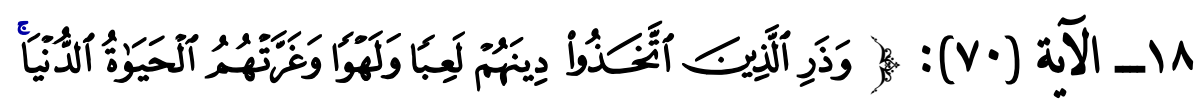

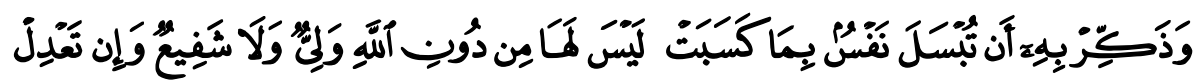

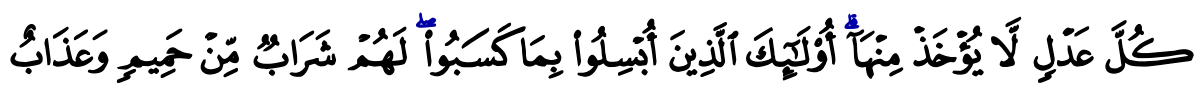

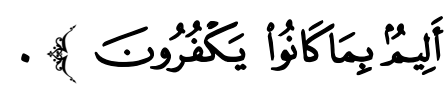

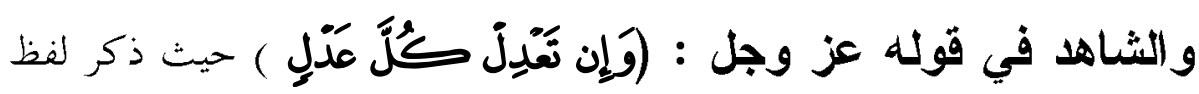




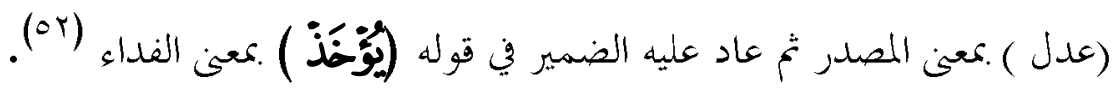

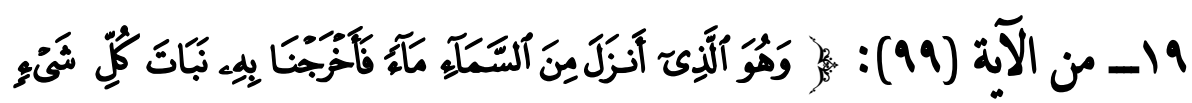

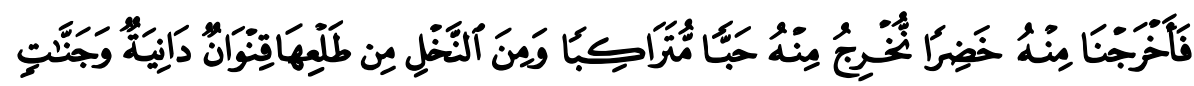

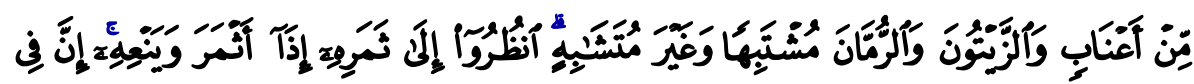

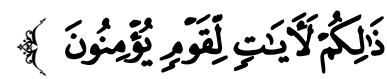

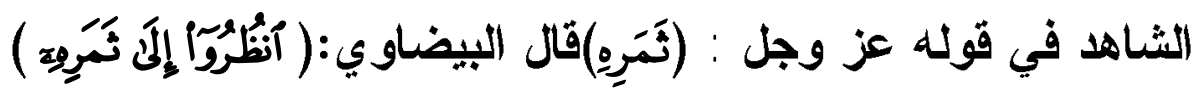
أي ثمر كل واحد من ذلك، قال الشهاب: "قوله: (أي ثمر كل واحد من ذلك)

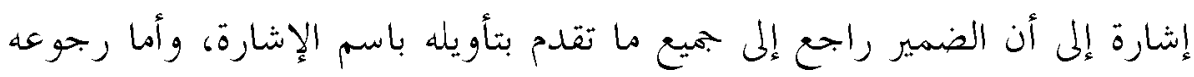

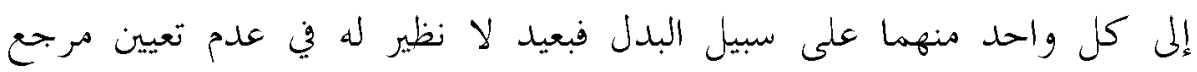
الضمير، وذلك إما إشارة إلى الرمان والزيتون، فيكون استخداماً على إرجاعه إليد لئه

$$
\begin{aligned}
& \text { باعتبار الشجر، وقد سبق ذكره .معني الثمر"(هاه). } \\
& \text { سورة الأعران (V) }
\end{aligned}
$$

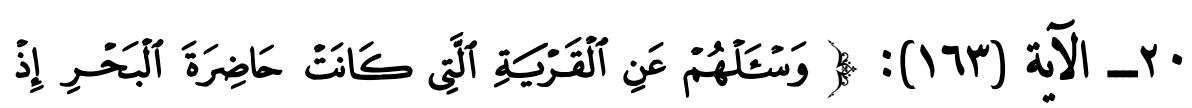

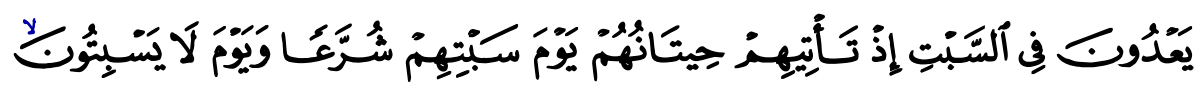

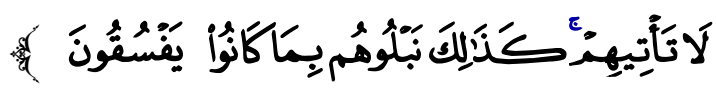

الشاهد في قوله عز وجل أهل القرية، قال الألوسي: "وضمير يعدون للأهل المقدر أو المعلوم من الكلام،

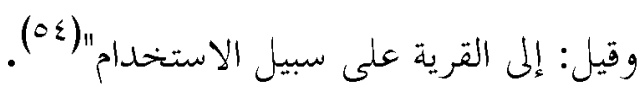

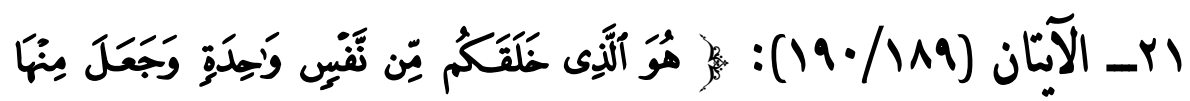




\section{مواطن ( الاستخدام ) البديعي في القرآن الكريم جمعاً ودراسة}

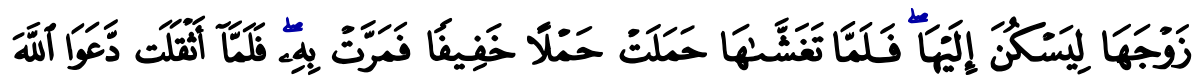

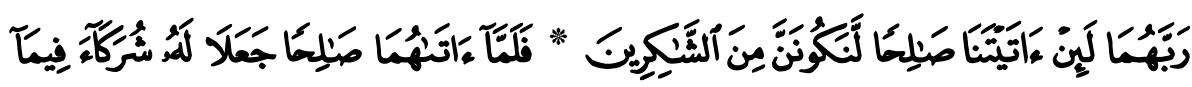

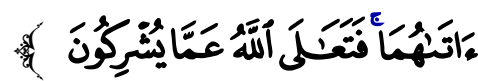

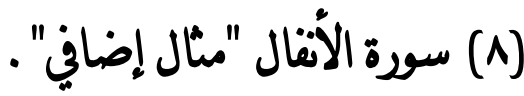

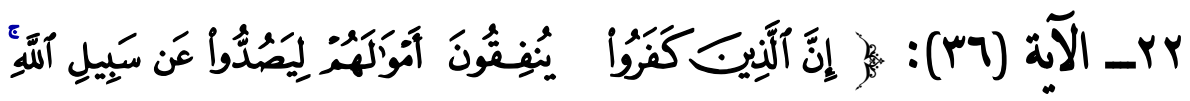

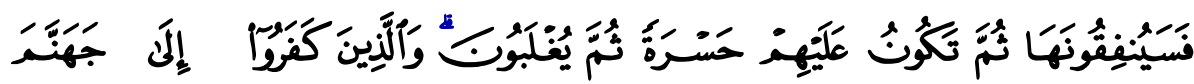

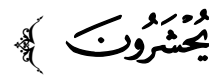

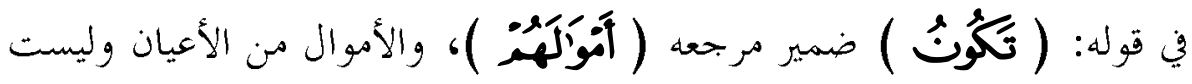
من المعاني، فكيف تكون الأموال حسرة، وإذا جعلنا الضمير العائد على الأموال معبن الإنفاق يكون هذا استخداماً، وهو وجه لمُ يُشِرِ إليه أحد في هذه الآية مع أنه

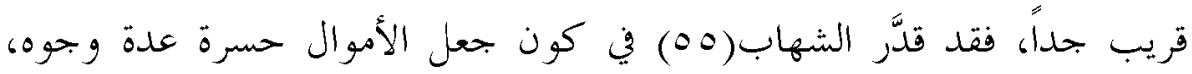
منها: الاستعارة، ومنها: التجوز في الإسناد على حد "فإنما هي إقبال وإدبار"،

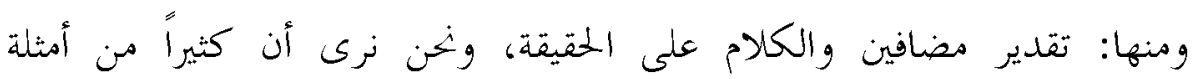
الاستخدام يكون وجه منها تقدير مضاف في مرجع الضمير.

أما الجديد في هذه الآية فهو شبه الاستخدام، وذللك في قول الله عز وجل: (والأين كفروا) الثانية، فقد قال البيضاوي: "أي الذين ثبتوا على الكفر

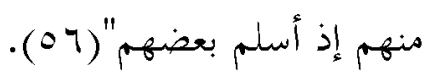
إذن (الذين كفروا) الثانية ليست هي الأولى التي في صدر الآية، فقد عادت الكلمة الظاهرة مرة ثانية بمعنى غير معناها الأول، وهذا عندهم يسمى شبه استخدام، و لم

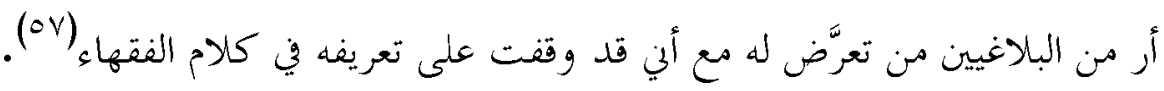




\section{(9) سورة التوة. - (9) - (9)}

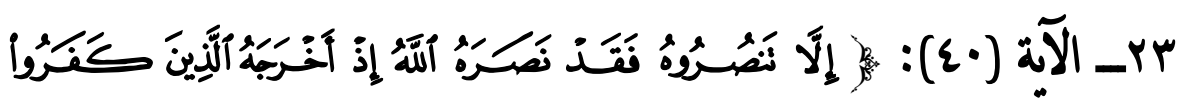

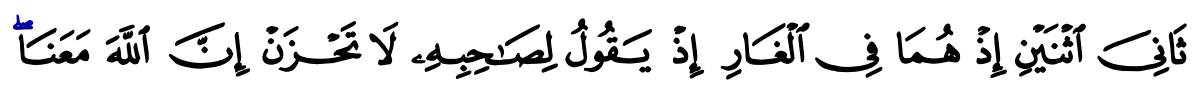

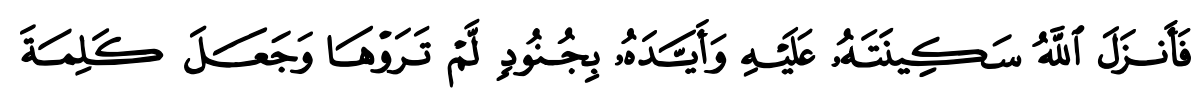

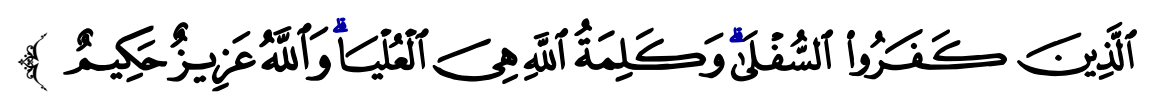
الشهاهد في قوله عز وجل:

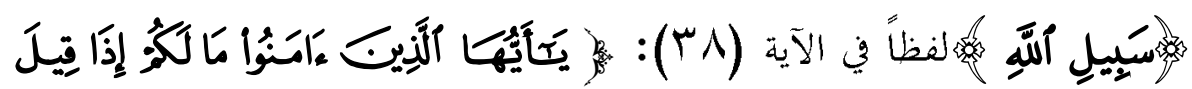

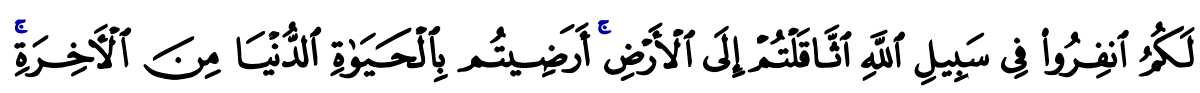

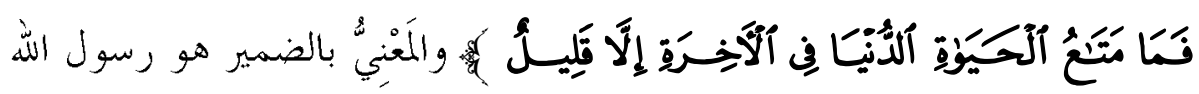
صلى الله عليه وسلم، يقول الإمام البقاعي: "والضمير للنبي صلى الله عليه وسلم إما على طريق الاستخدام من (سَبِيلِل آلَّهِ )؛ لأنه الموضح له، الداعي إليه، أو لتقدم اسمه الشريف إضماراً في قوله: ( إذذا فِيلَ كَكُ" ) أي من رسول الله صلى عليه

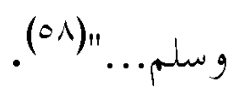

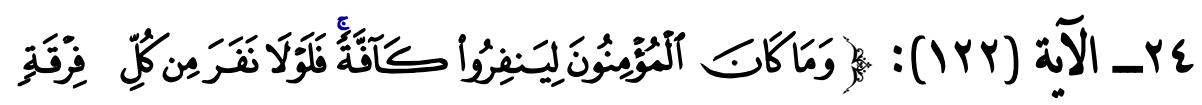

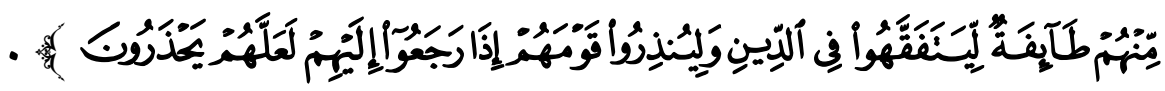
يقول الطاهر بن عاثور : "ويجوز أن يكون المراد من النَّنْ في قوله:

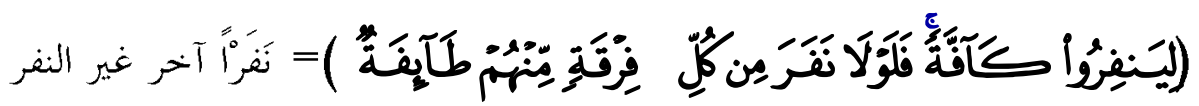

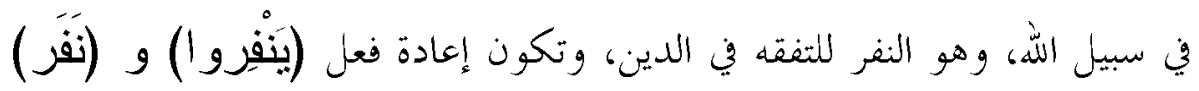

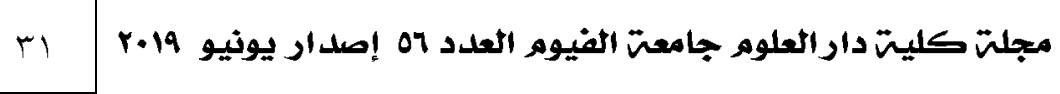


من الاستخدام بقرينة قوله: ليتفقهوا في الدين، فيكون الضمير في قوله:

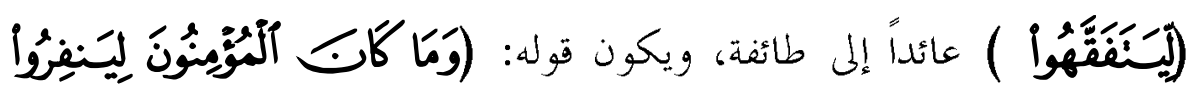

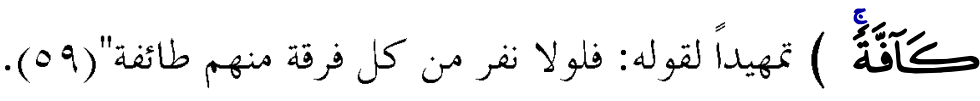

$$
\begin{aligned}
& \text { (·) سورة يونس . }
\end{aligned}
$$

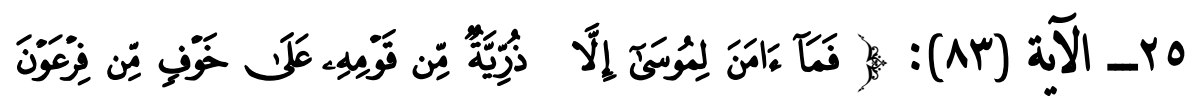

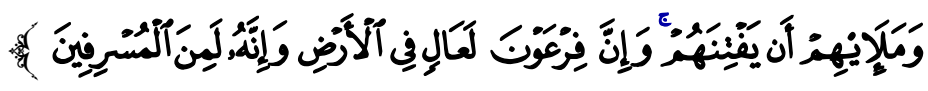

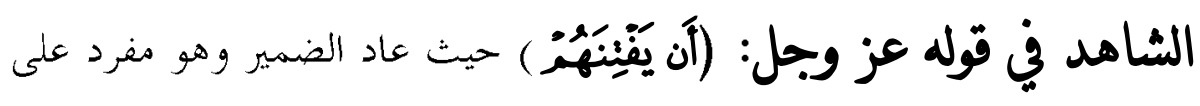

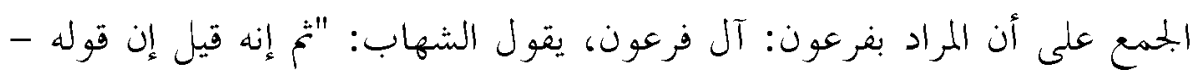

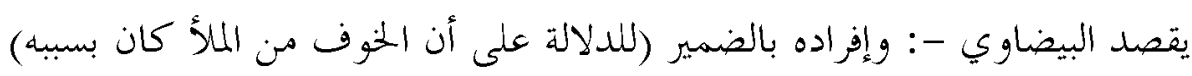

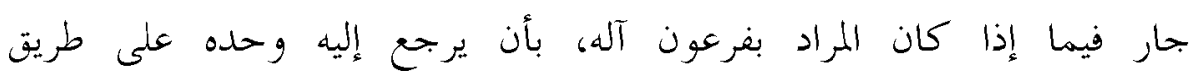

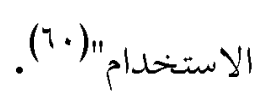

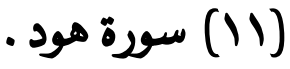

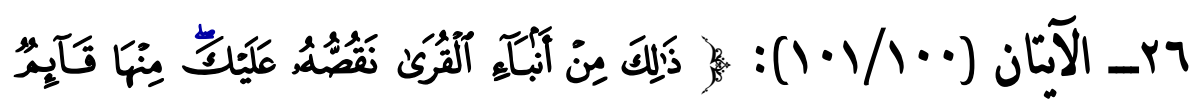

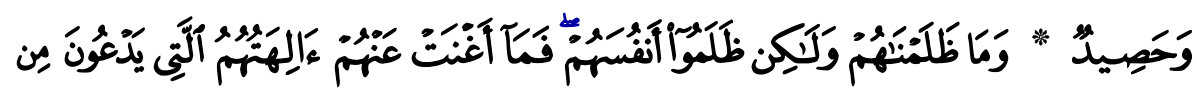

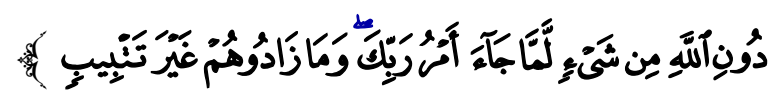

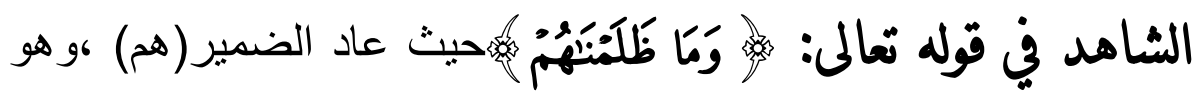
جمع على القري وهى مفرد لأن المقصود به أهل القرى على أسلوب

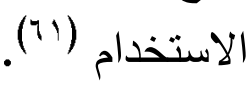




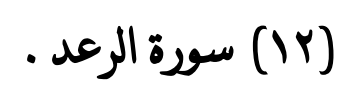

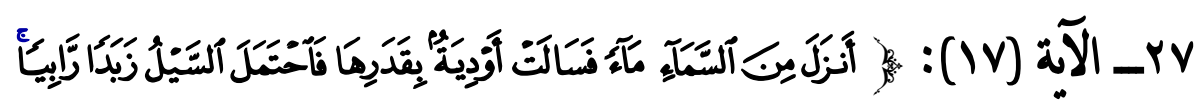

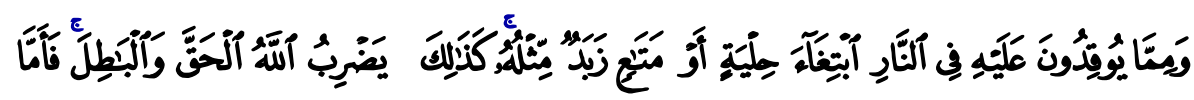

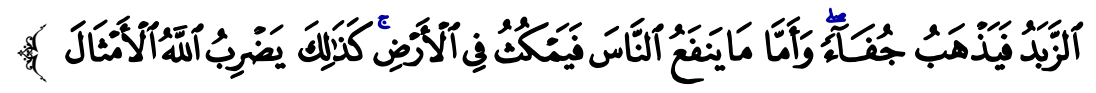

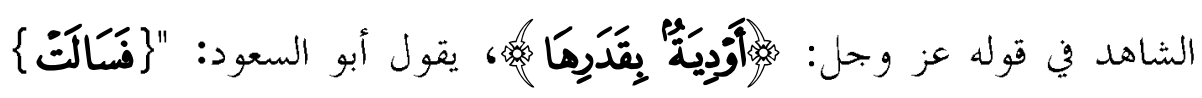
بذلك \}أَّديَّةُ \{و واقعة في مواقعه (أي السيل أو الماء) لا جميعُ الأودية؛ إذ الأمطار

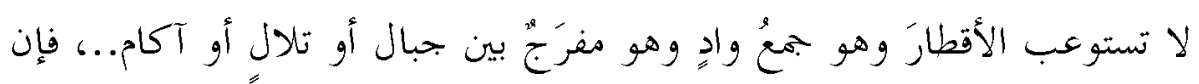

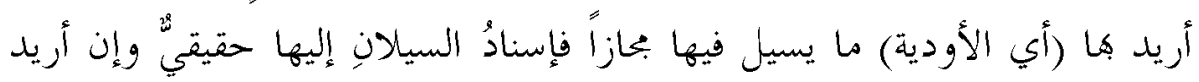
معناها الحقيقيٌّ فالإسنادُ بحازيٌّ كما في جرى النهرُ..، $\}$ ملتبسةً بمقدارها الذي عينه الله تعالى واقتضتْه حكمثه في نفع الناس أو .مقدارها

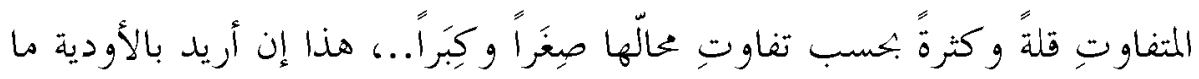

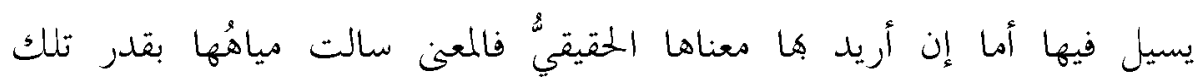

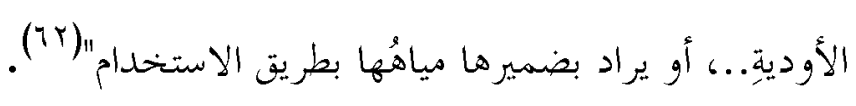

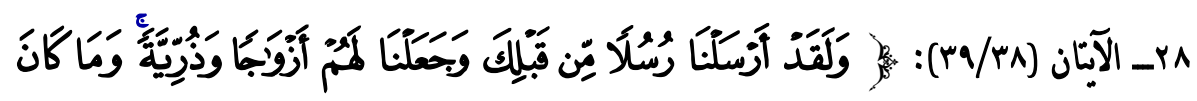

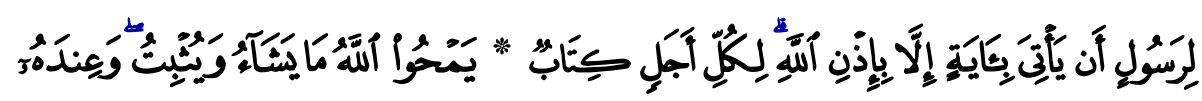

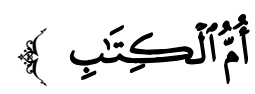
قال صفي الاين الحلي (ت ، ه Vهـ): "و كذلك قوله سبحانه وتعالى:

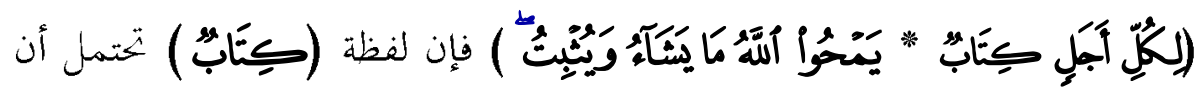
يراد بها الأجل الختوم والكتاب المكتوب، وقد توسطت بين لفظيت (أَجلِ ) و 
(يمتحوًا ) فاستخدمت أحد مفهوميها وهو الأمد، بقرينة ذكر الأجل، واستخدَدْت المفهومَ الآخر وهو الكتاب المكتوب بقرينة (يمنْوُاً )"(r").

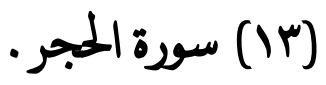

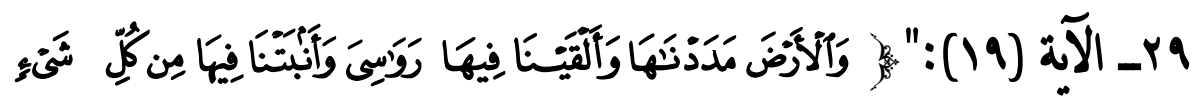
تَوْنْونِ الشاهد في قوله عز وجل: (وَأَبْتَتْا فينَّا ) أي في الأرض، وهي إما شاملة للجبال؛ لأكا تعد منها، أو خاصة بغيرها؛ لأن أكثر النبات وأحسنه في ذلك، وجُوٍِّ أن

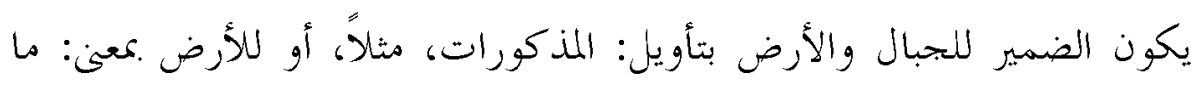

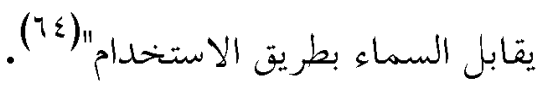

\section{• (1ع) سورة النحل}

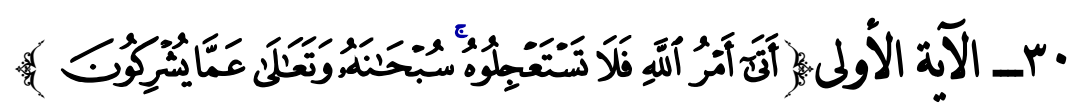
قال الحافظ السيوطي: "وقد استخرجت بفكري آيات على طريقته (يقصد السكاكي) منها قوله تعالى: وبعثة البيي صلى الله عليه وسلم، وقد أريد بلفظه الأخير، كما أخرج ابن مرَدْوَيَهِ من طريق الضحاك عن ابن عباس في قوله تعالى:

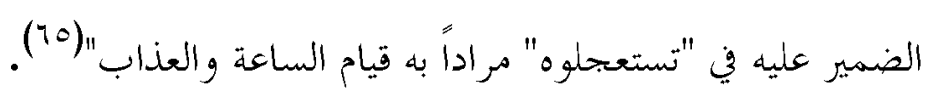

اrـ الآمة (V)

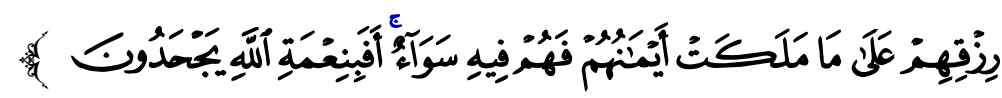




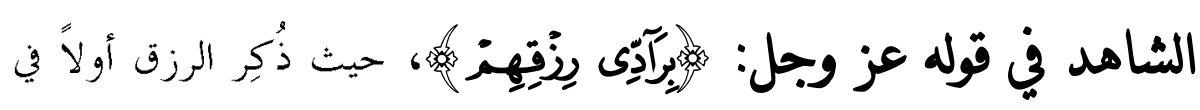

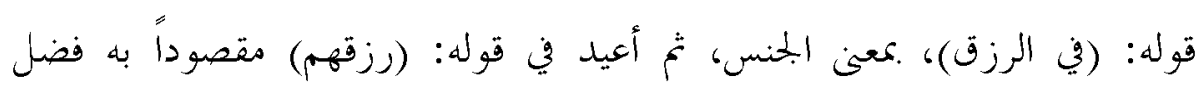

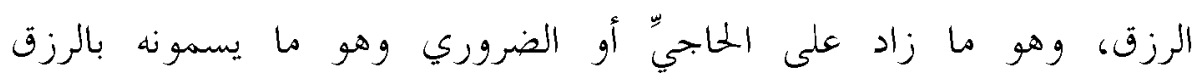
التكميلي(71).

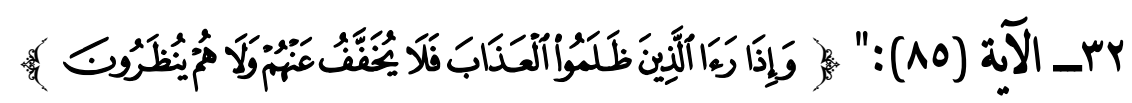

الشاهد في قوله تعالم:

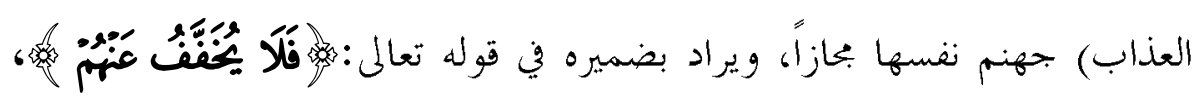

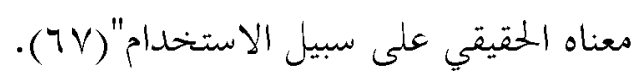

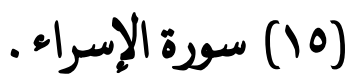

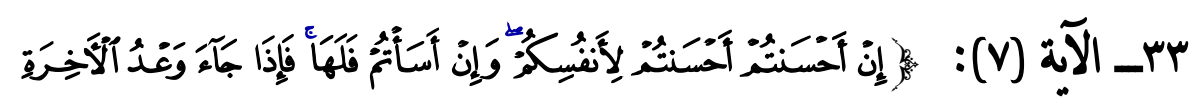

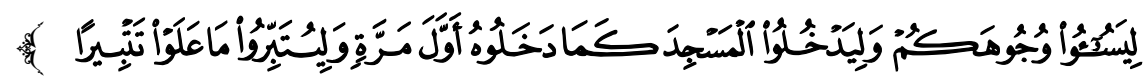

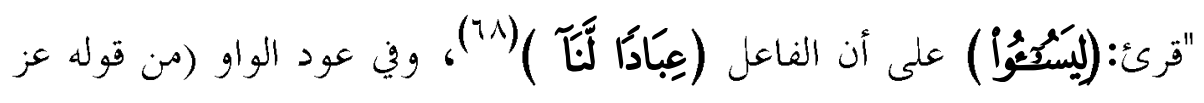

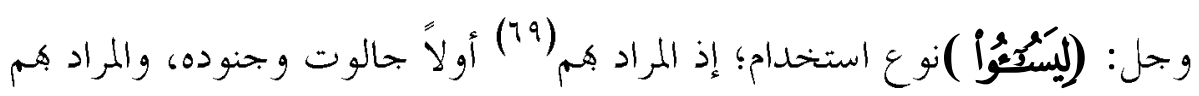

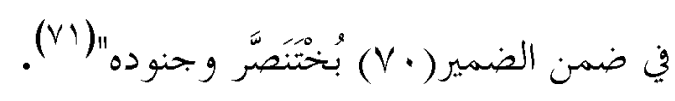

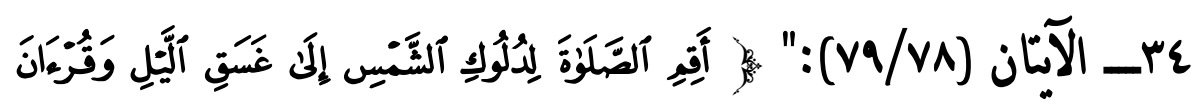

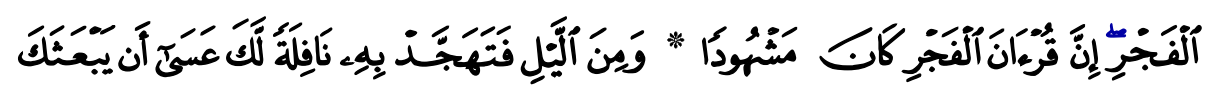

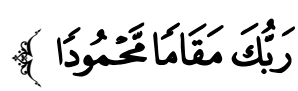




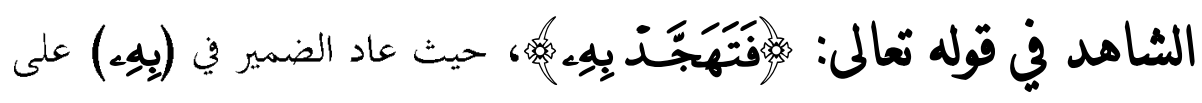

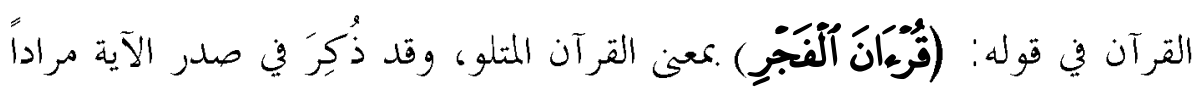

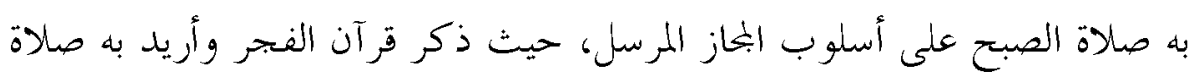

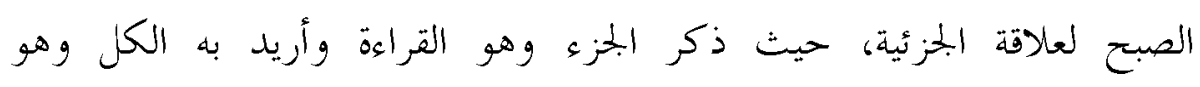

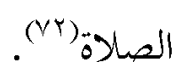

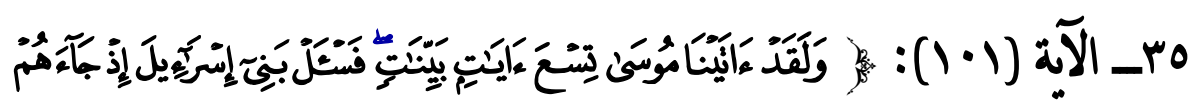

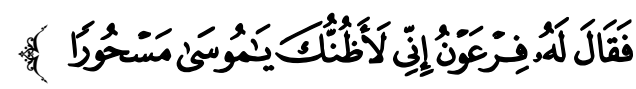

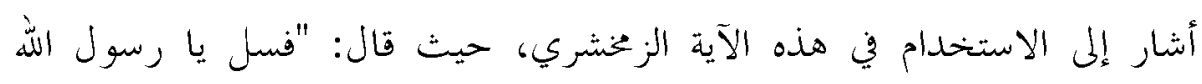

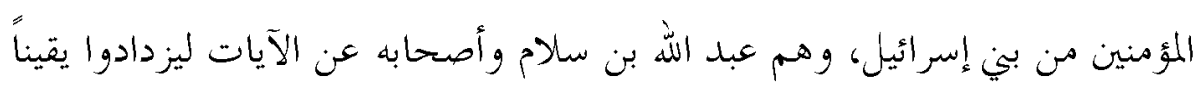

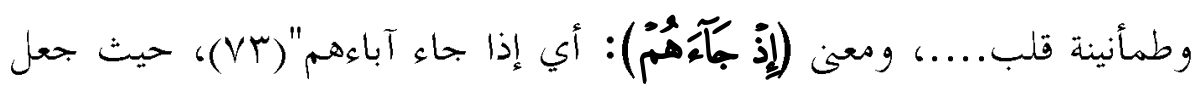

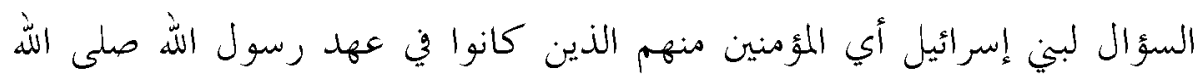

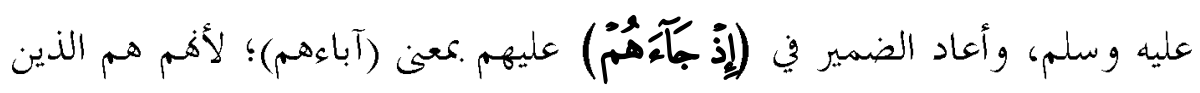
جاءهم مو سى على نبينا وعليه أفضل الصلاة والسلام. (17) - (17) سورة الكهف.

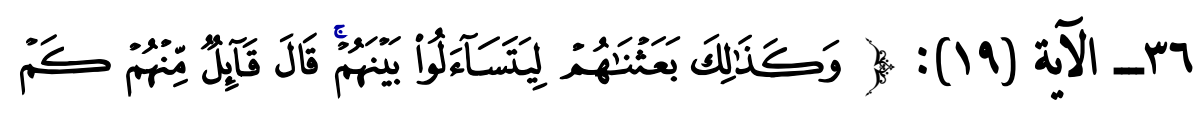

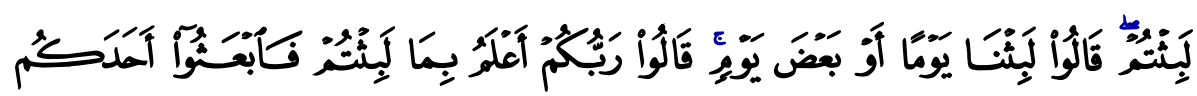

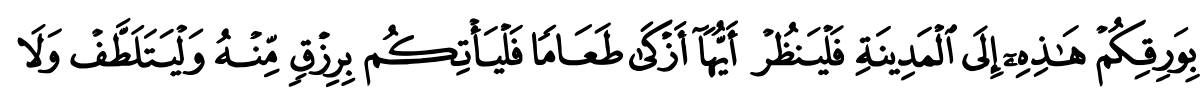

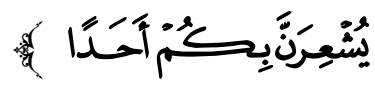
فسر البيضاوي قوله عز وجل:(ألمَدِينَةِ ) فقال: "أي أهلها" قال الشهاب: 


\section{مواطن ( الاستخدام ) البديعي في القرآن الكريم جمعاً ودراسة}

"يعين أنه بتقدير مضاف، وهذا أحسن من جعل الضمير للمدينة مراداً هـا أهلها

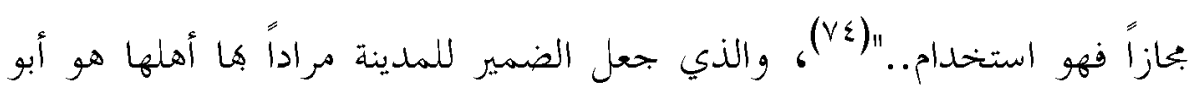

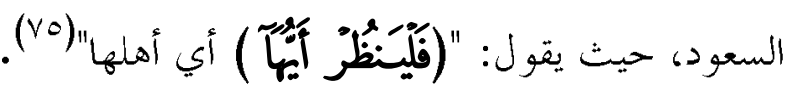

$$
\begin{aligned}
& \text { سورة طه. (IV) }
\end{aligned}
$$

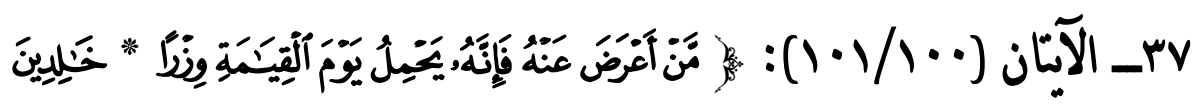

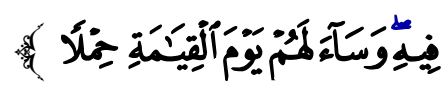

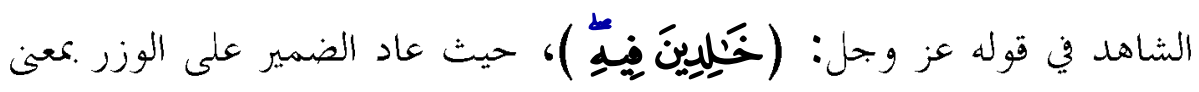
العقوبة على الوزر، وهذا على تفسير (الوزر) بالإثم العظيم، قال الثهاب:

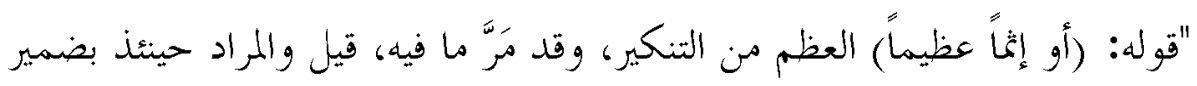

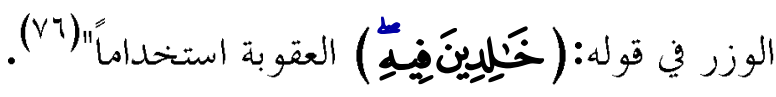

$$
\begin{aligned}
& \text { (11) سورة الأبنياء . }
\end{aligned}
$$

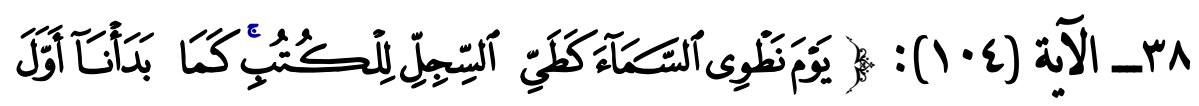

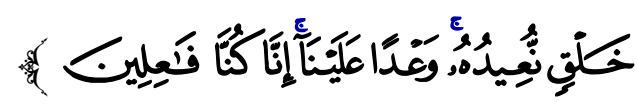

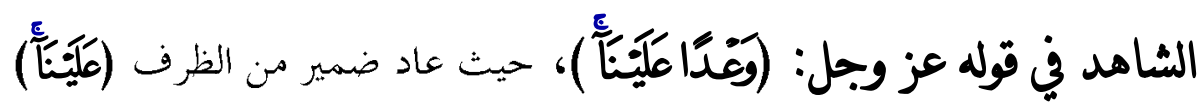
على الوعد (وعَدًُا ) مععن الإبحاز، قال الثهاب: "وقوله: علينا إبحازه، تفسير معنى لا إعراب، ويمتمل أنه إشارة إلى تقدير مبتدأ خبره الظرف، لا لأنّ (إبخازه)

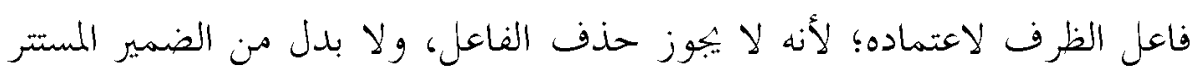


في الظرف العائد على الوعد بمعنى الإنجاز استخداماً لتكلفه"(VV).

$$
\text { • (19) سورة الحجّ }
$$

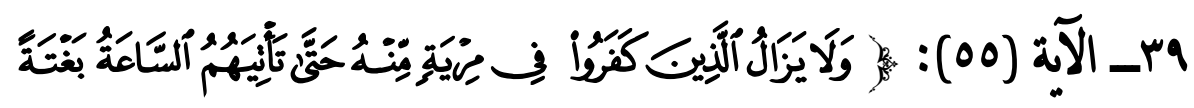

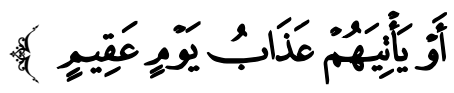

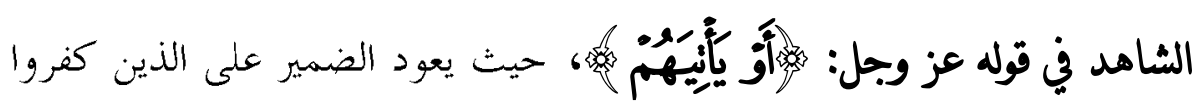
المذكورين في صدر الآية على الكفار الذين في عهد رسول الله صلى اللّ عليه وسلم، وذلك إذا فسرت الساعة بالقياهة، ووالذين كفروا) أي الجنس،

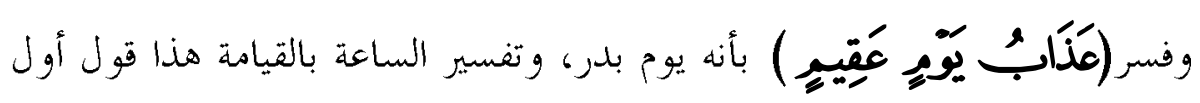

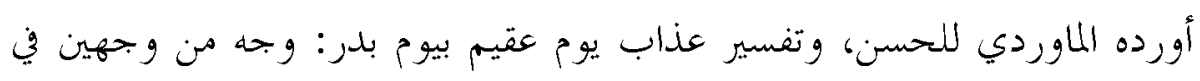

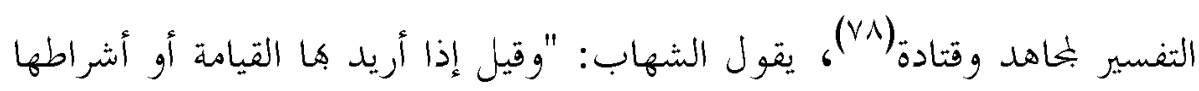
فالمراد بالذين كفروا الجحنس والآية تتضمن الأخبار عن بقاء الجنس إلى القيامة لكن

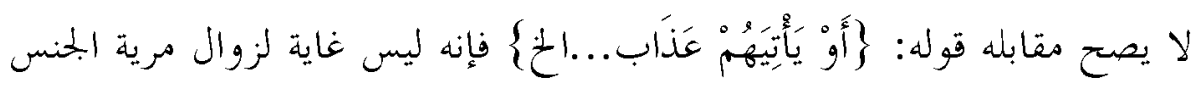

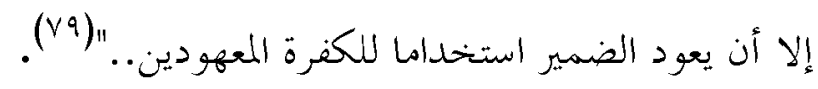

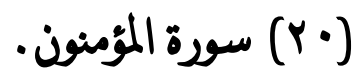

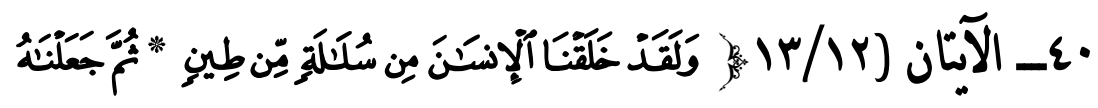

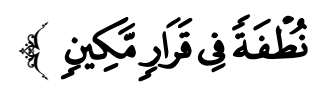
أول من أشار إلى الاستخدام في هذه الآية الزركشي (ت ع9 وهـ) في

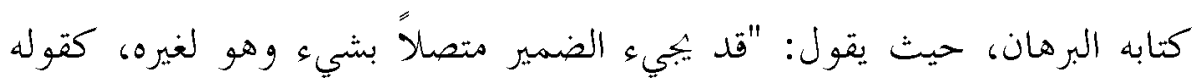

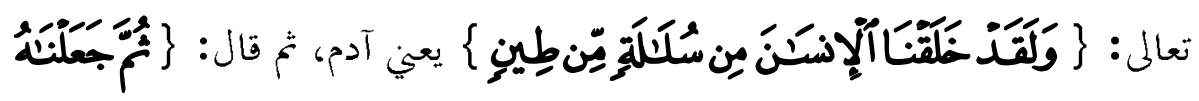




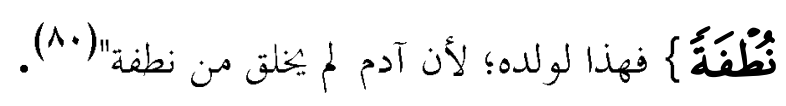

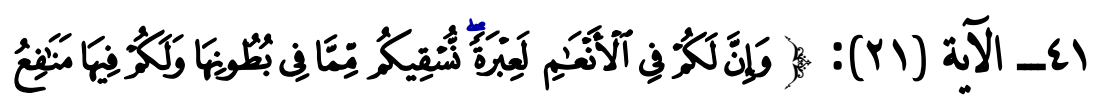

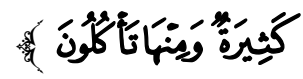

الشاهد في قوله عز وجل: مؤنثاً (وهو اسم مفرد؛ لأنه اسم جمع يذكر معه الضمير لو أريد به جميع أفراده)؛

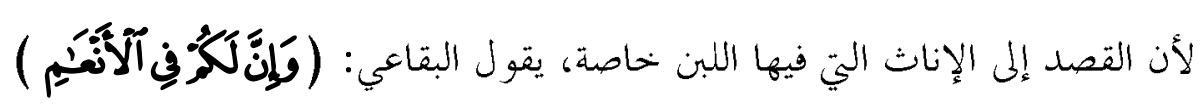

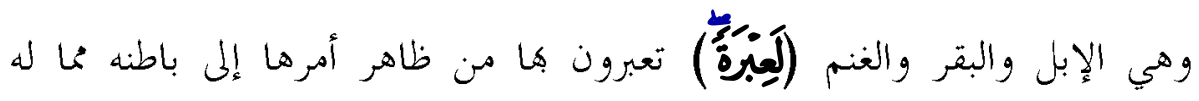
سبحانه فيها من القدرة التامة على البعث وغيره؛ ثم استأنف تفصيل ما فيها من

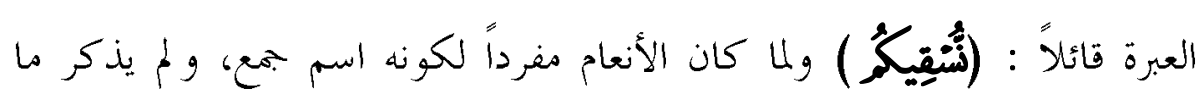

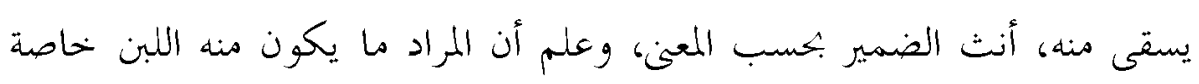

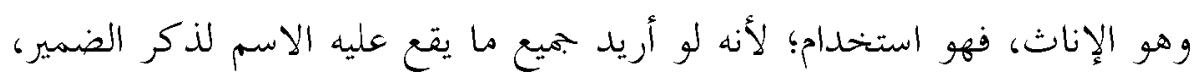

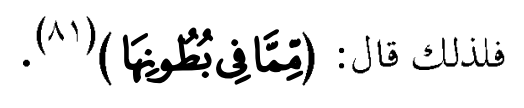

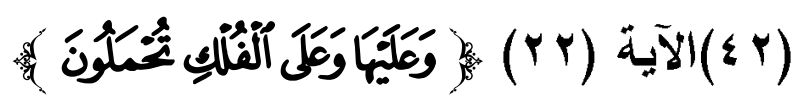

الشاهد في قوله عز وجل: (وَعَكَهَها )حيث عاد الضمير على الأنعام مراداً به الإبل خاصة؛ لأها هي المعدة للحمل عليها وليس كل الأنعام كذلك، يقول الألوسي: "

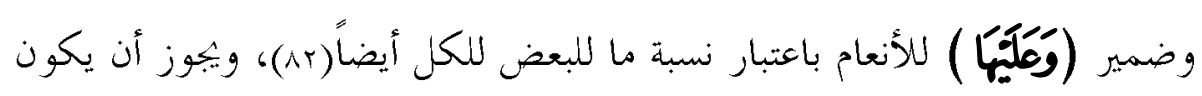

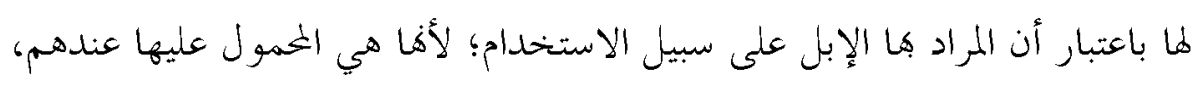

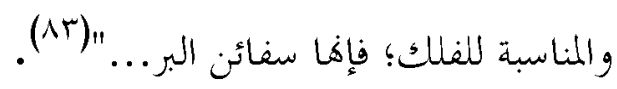




\section{مواطن ( الاستخدام ) البديعي في القرآن الكريم جمعاً ودراسة}

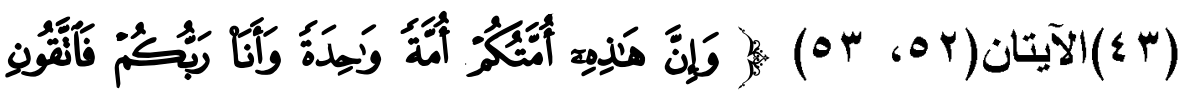

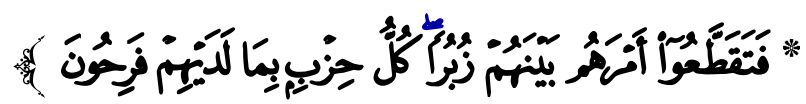

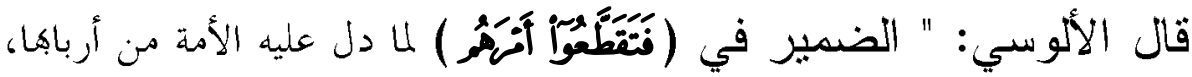

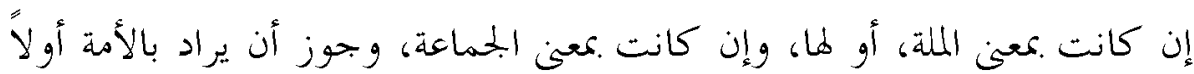

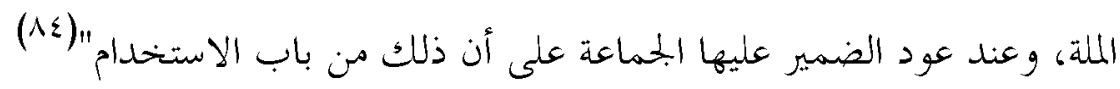

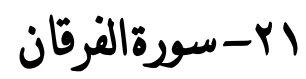

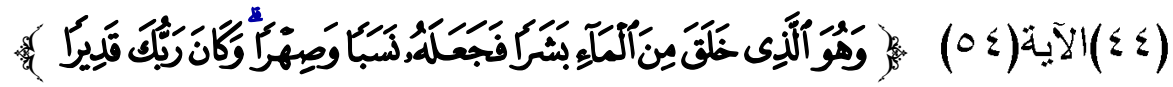

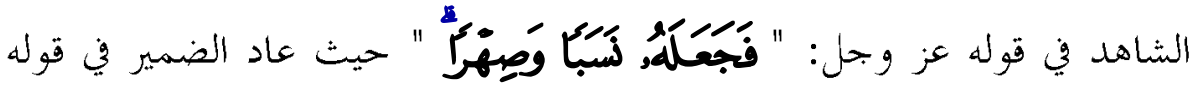
(فَجَعَكلُو ) على قوله "بشرا" .بمعنى غير معناه الأول على تفسير البشر بآدم وتفسير

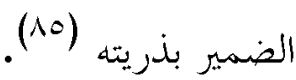

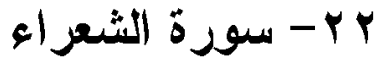

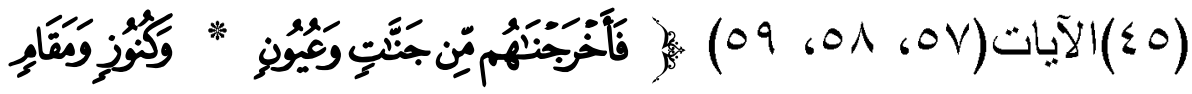

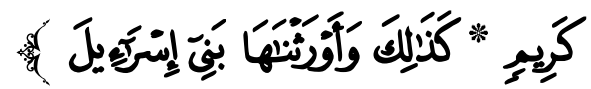
الثَاهد في قوله عز وجل " وَأَوْرَثْنَاهَا بَنِى إِسْرَاِِيَلَ " حيث عاد الضمير

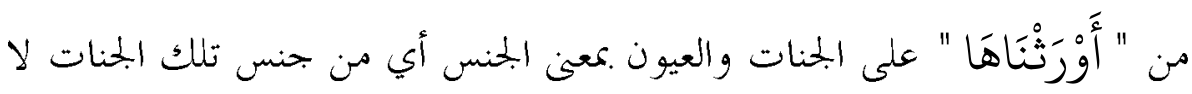

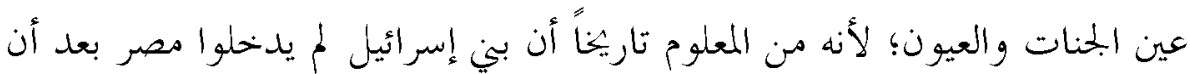

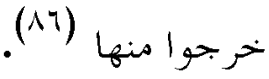




\section{r r سورة النمل}

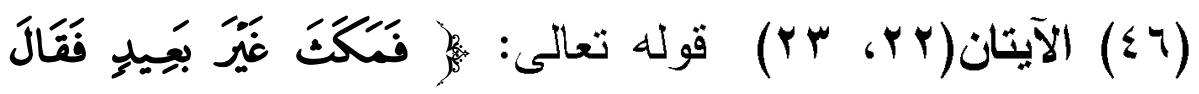

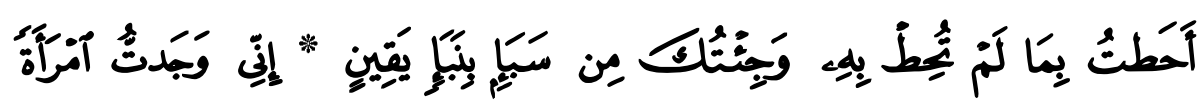

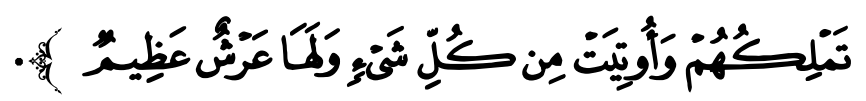

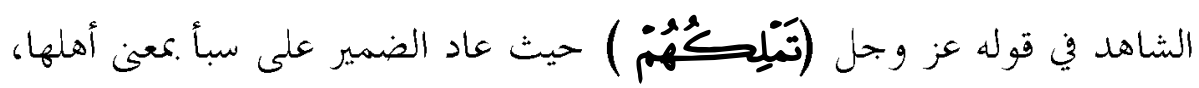
وقد ذكرت قبل بمعني المدينة (NV)

צ - سورة القصص

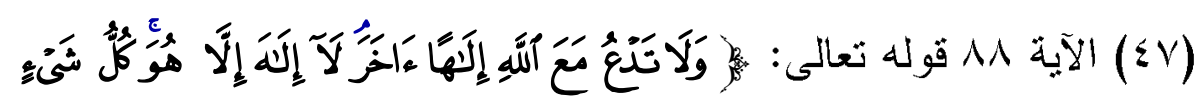

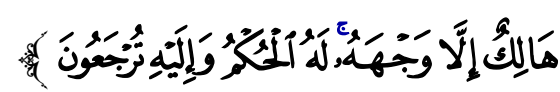

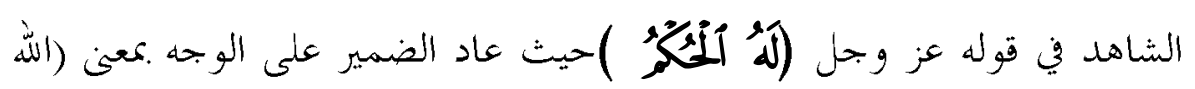

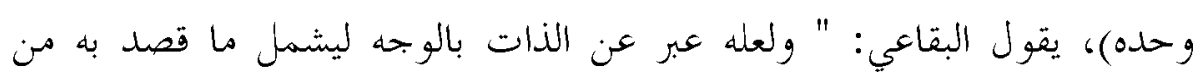

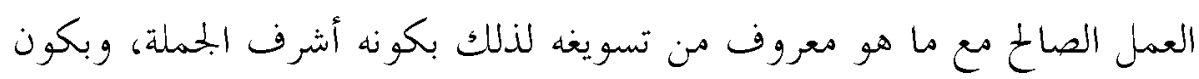
النظر إليه هو الحامل على الطاعة بالاستحياء وما في معناه، ثم على مل ذلك

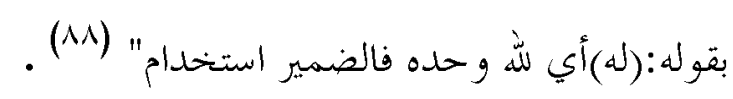

\section{• - سورة العنكبوث}

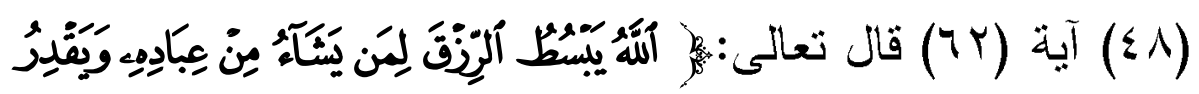

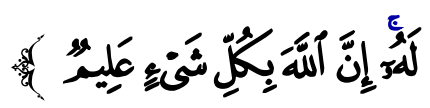
قال الألوسي: " الله يبسط الرزق لمن يشاء أن يبسطه له لا غيره (مِنْ عِبَادِهِ وَيَقْدِرُ لَهُ)أي يضيق عليه، والضمير عائد على من يشاء الذي يبسط له الرزق أي 
عائد عليه مع ملاحظة متعلقه فيكون المعيى أنه تعالى شأنه يوسع على شخص واحد

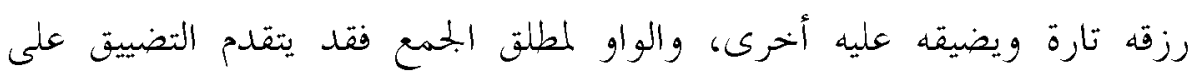
التوسيع، أو عائد على (من) يشاء بقطع النظر عن متعلقه فالمراد (من) يشاء آخر

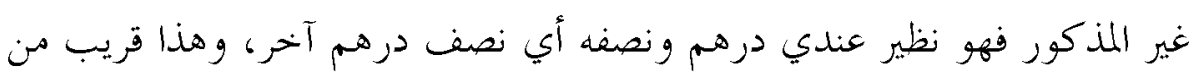
الاستخدام، فالمعنى أنه تعالى شأنه يوسع على بعض الناس ويضيق على بعض

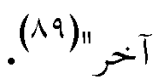

\section{(لج - سورة الروم}

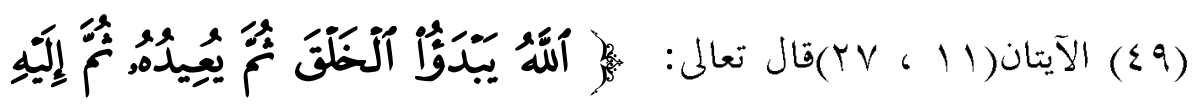

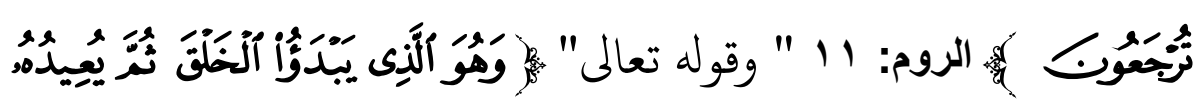

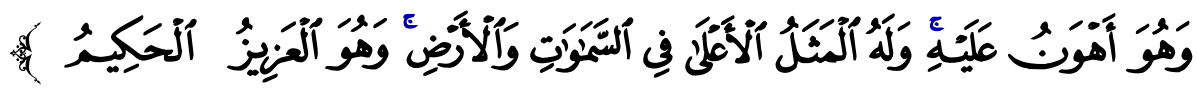
الروم: rv الشاهد في قوله عز وجل (تَُّّ يُعِيدهُه) حيث ذكر الخلق أولاً بمعنى المصدر ثمَ أعيد

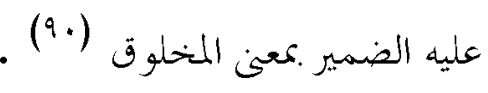

\section{rV}

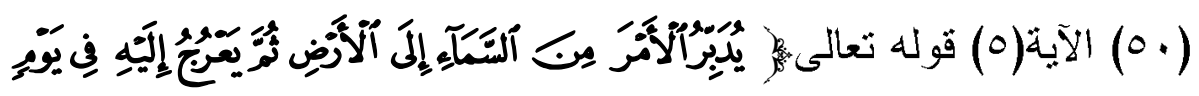

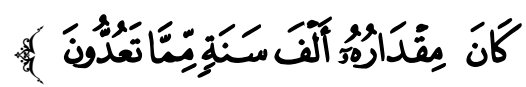

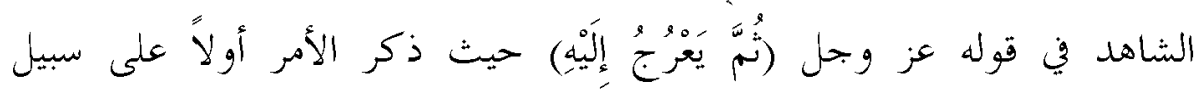

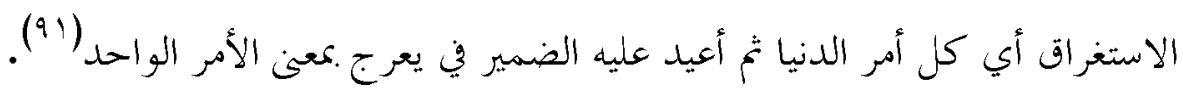

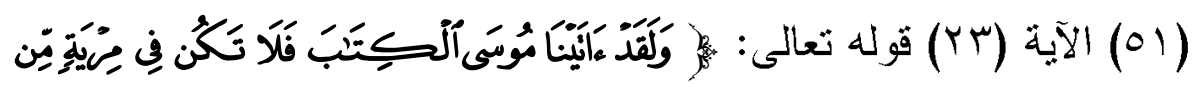

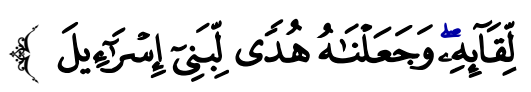




\section{ـــــــ مواطن ( الاستخدام ) البديعي في القرآن الكريم جمعاً ودراسة}

الشاهد في قوله عز وجل (لِّقائئه) حيث عاد الضمير البحرور على الكتاب بمعين

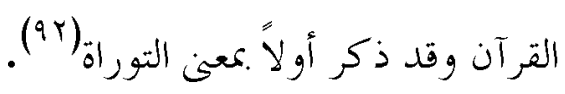
ب - سورة الأحز اب أب

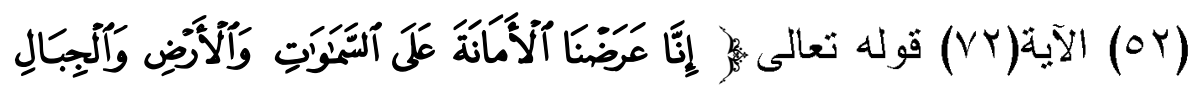

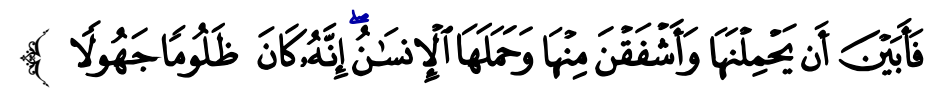
الشاهد في قوله عز وجل (إنه) حيث عاد الضمير على الإنسان بمعنى الكافر وقد وائد

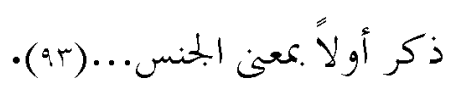

\section{ج - سورة سبأ}

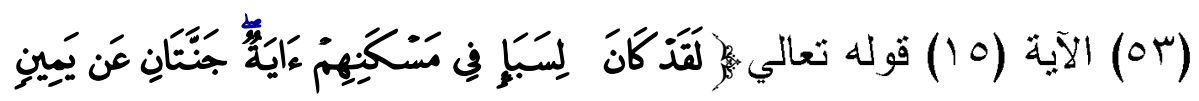

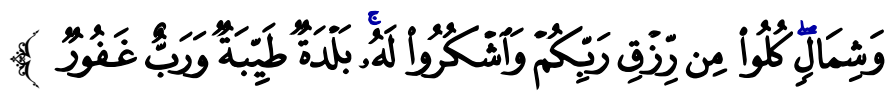
الشاهد في قوله عز وجل (مستكِنِهُم ) حيث عاد الضمير على سبأ بمعنى الأهل

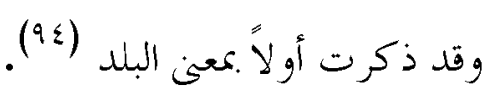

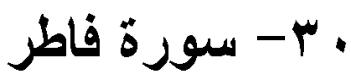

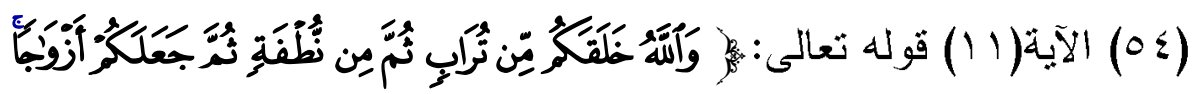

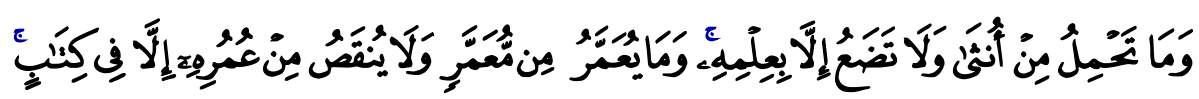

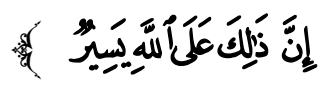
الشاهد في قوله عز وجل (مِنْ عُمُرِِ) حيث عاد الضمبر البحرور على المعمر بمعني

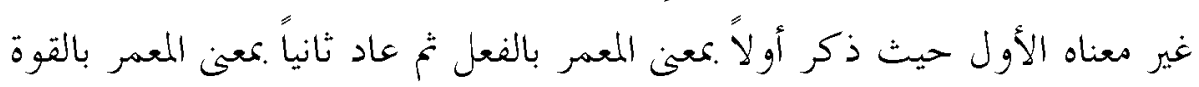
أي مَن شأنه أن يعمر (90) 


\section{ا س - سورة بس}

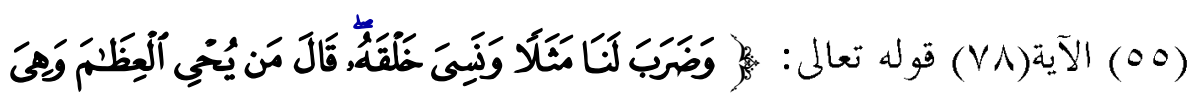

\section{كرمِيـر}

الشاهد في قوله عز وجل (وَهَهَ رَمِيمُم) حيث عاد الضمير على العظام بمعنى

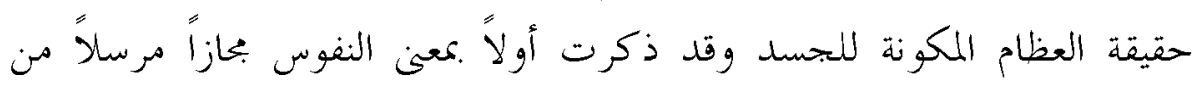

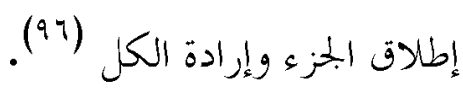
r r- سورة الزيمر

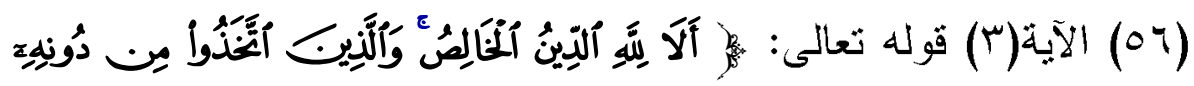

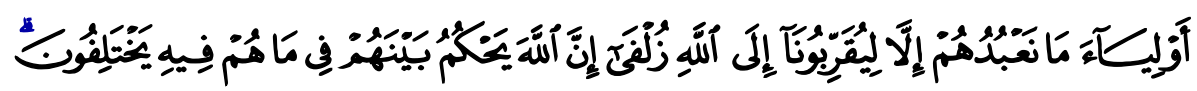

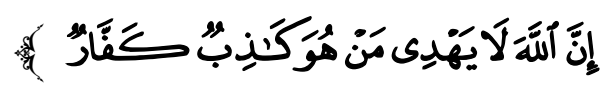

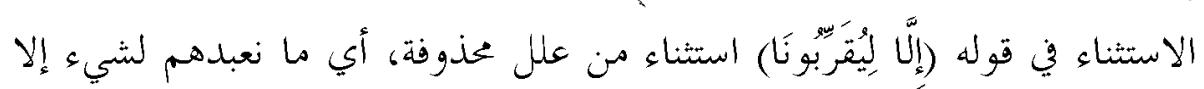

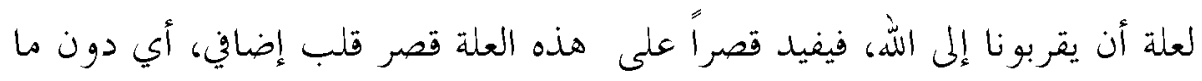

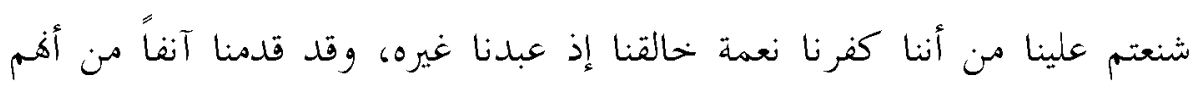
أرادوا به المعذرة، ويكون في أداة الاستثاء استخدام، لأن اللام المقدرة قبل الاستثناء لام العاقبة لا لام العلة إذ لا يكون الكفران بالحالق علة لعاقل ولكنه صائر

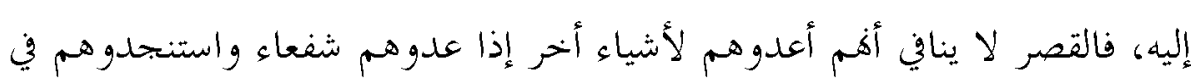
النوائب، واستقسموا بأزلامهم للنجاح، كما هو ثابت في الواقع" (vi").

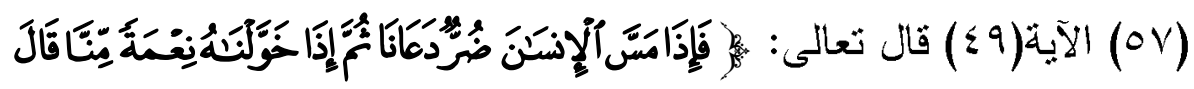

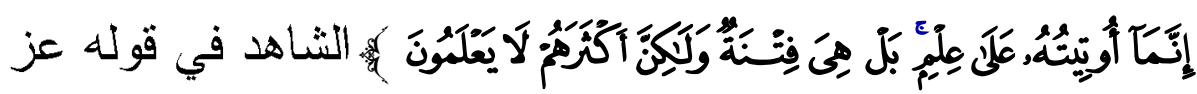

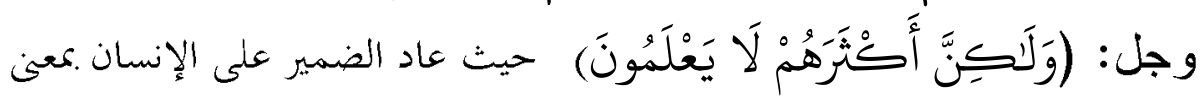




\section{ـــــــ مواطن ( الاستخدام ) البديعي في القرآن الكريم جمعاً ودراسة}

الجحنس والمراد بالإنسان على بعض التفاسير قيل حذيفة بن المغيرة، وقيل الكفرة،

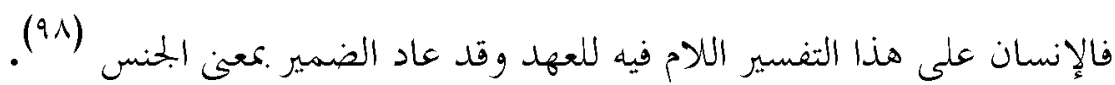

$$
\text { ب س سورة فصلم }
$$

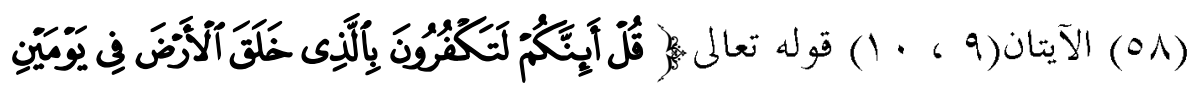

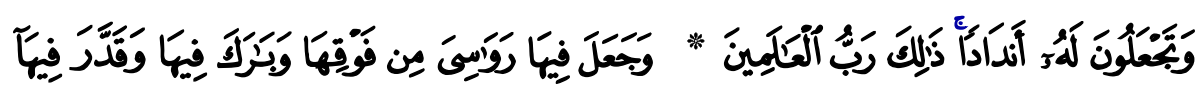

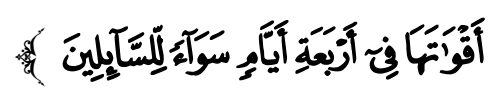

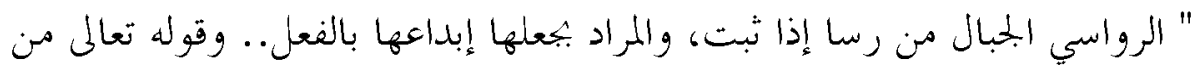

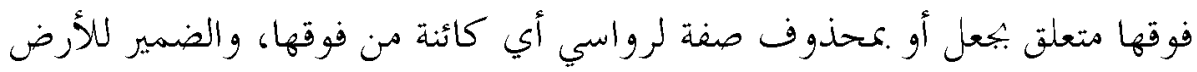

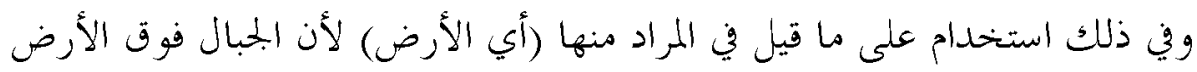

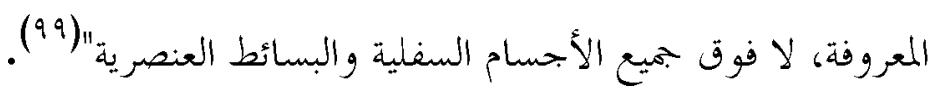

$$
\text { ع س- سورة الأريات }
$$

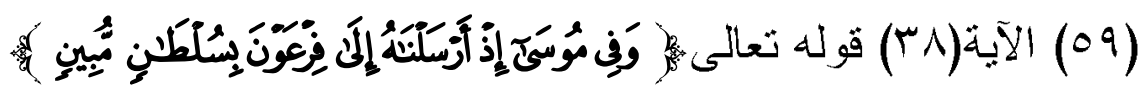

\section{مثنال إضنافي}

الاستخدام كما يكون في الضمير يكون في حرف العطف " قوله: وفي موسى" عطف على قوله "فيها آية" والتقدير: وتركنا في موسى آية، فهذا العطف من

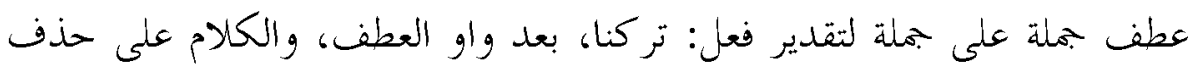
مضاف، أي في قصة موسى حين أرسلناه إلى فرعون بسلطان مبين فتولى.. الخا،

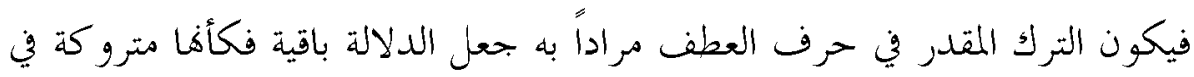

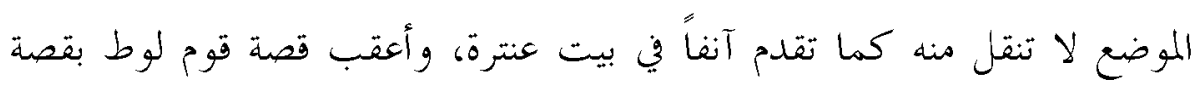
موسى وفرعون لشهرة أمر موسى وشريعته، فالترك المقدر مستعمل في مبازيه 


\section{مواطن ( الاستخدام ) البديعي في القرآن الكريم جمعاً ودراسة}

المرسل والاستعارة، وفي الواو استخدام مثل استخدام الضمير في قول معاوية بن

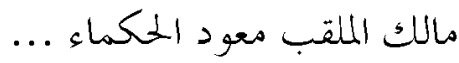
رعيناه وإن كانوا غضابا(..)

$$
\begin{aligned}
& \text { إذا نزل السماء بأرض قوم } \\
& \text { والمعنى أن قصة موسى آية دائمة.."(1. (1). }
\end{aligned}
$$

\section{ه ب- سورة الو اقعة}

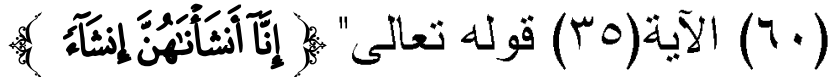

حيث عاد الضمير في قوله عز وجل أنشأناهن على الفرش مععن نساء أهل الدنيا

$$
\text { وقد ذكرت الفرش قبل ذلك بمعنى ما يفرش من المتاع (r.1). }
$$

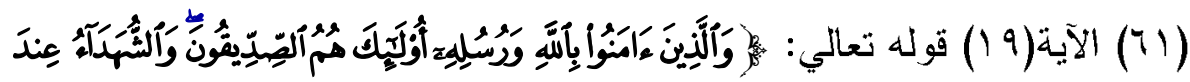

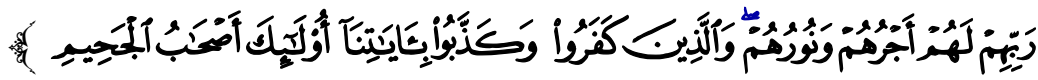
الشاهد في قوله عز وجل (أجرهم ونورهم)ففيهما ضميران عائدان إلى لفظي

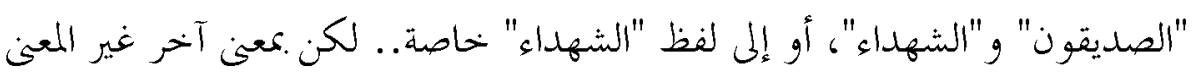
الذي حمل عليه آنغا (من كوفما المقصود هما المؤمنون من أمة الإسلام وصفوا بالصديقية لأفم صدقوا بجميع الرسل وبالشهداء لأهم يشهدون على جميع الأمم) بل .معتي الصديقين والشهداء ممن كانوا قبلهم من الأمم، قاله في الكشاف، ومعنى الصديقين والشهداء حينئذ مغاير للمعنى السابق بالعموم والخصوص على طريقة الاستخدام في الضمير، وعلى طريقة التشبيه البليغ في حمل الخبر على المبتدأ في قوله

$$
\text { "هم أجرهم ونورهم" بتقدير: لهم مثل أجرهم ونورهمب..." (r.). }
$$

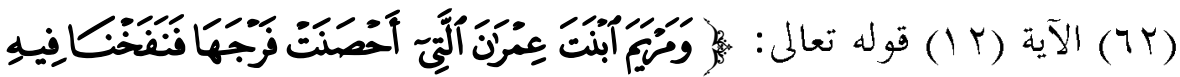

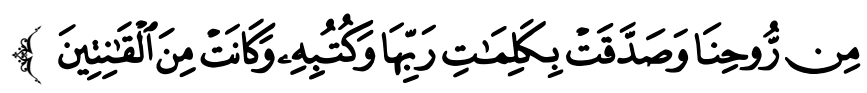




\section{مواطن ( الاستخدام ) البديعي في القرآن الكريم جمعاً ودراسة}

الشاهد في قول الله عز وجل "فنفخنا فيه" حيث عاد الضمير الخحرور على لفظ

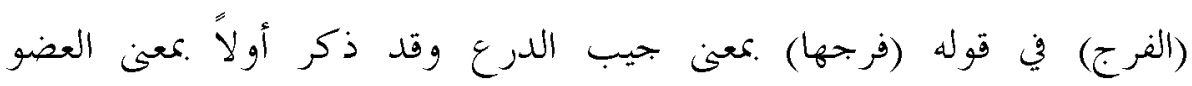

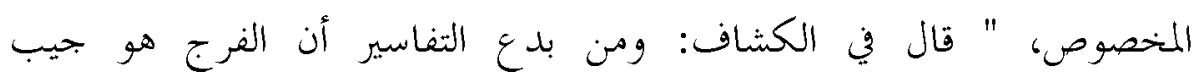
الدرع(؟.1)، ومعين أحصنته منعته، فنفخنا فيه الفاء للسببية، والنفخ نفخ الريح في الشيء أي فنفخنا بسبب ذلك في فرجها على أن يكون المراد بالفرج هنا الجيب...

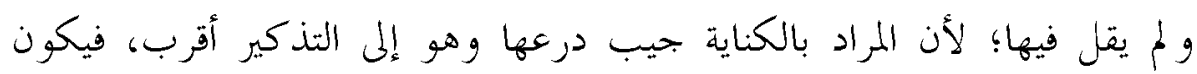
قوله(فيه)من باب الاستخدام، لأن الظاهر أن المراد بلفظ الفرج العضو، وأريد

$$
\begin{aligned}
& \text { بضميره معنى آخر للفرج ومنه قوله تعالى:" وما لها من فروج ..." (1.). } \\
& \text { ش }
\end{aligned}
$$$$
\text { (مثال إضنافي) }
$$

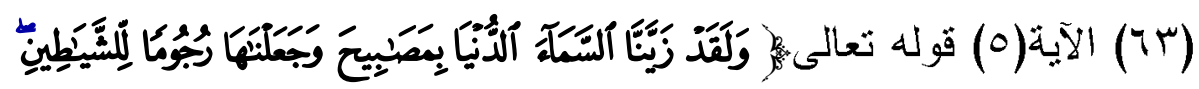

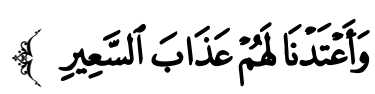
الشاهد في قوله عز وجل(وجعلناها) حيث عاد الضمير المنصوب(ها)على المصابيح

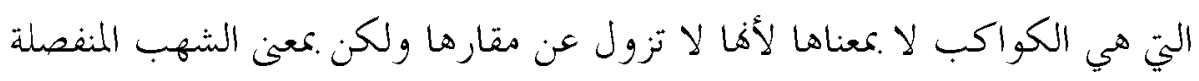

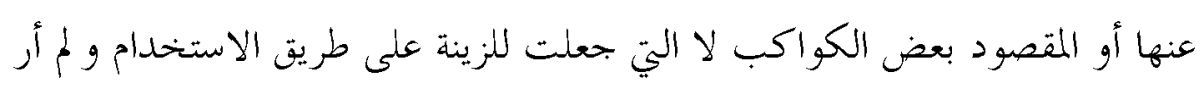
من المفسرين من أشار إلى هذا الموطن مع ظهوره، يقول قتادة في ذلك:" خلق الله

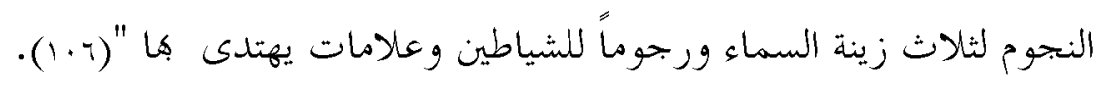

\section{ج س- سورة المحاقة}

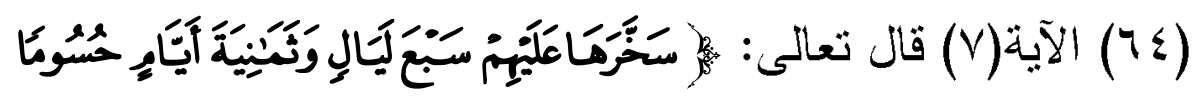

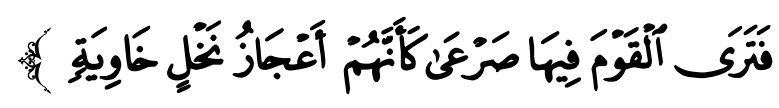


الشاهد في قوله عز وجل "خاوية" وهذه اللفظة بحرورة باتفاق القراء فتعين أن تكون صفة لـــ "نخل" ووصف "نخل" بأها "خاوية" باعتبار إطلاق اسم "النخل"

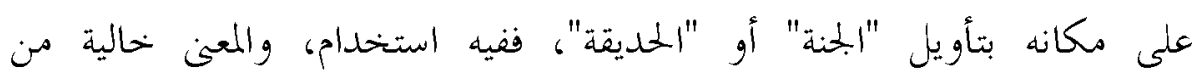

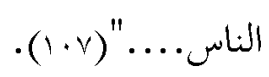

\section{. ع - سورة المدثر}

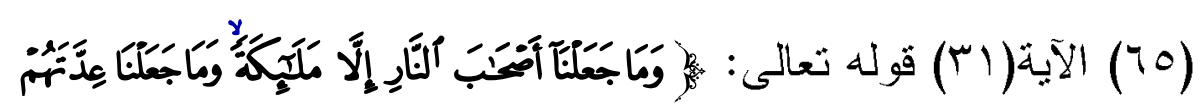

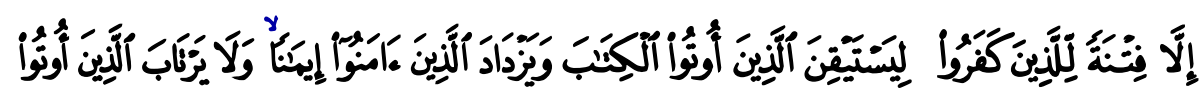

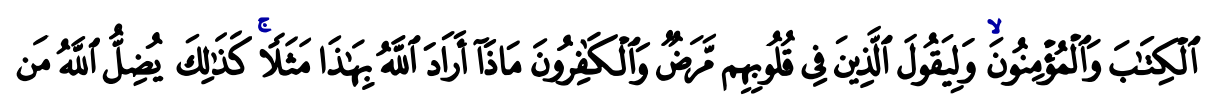

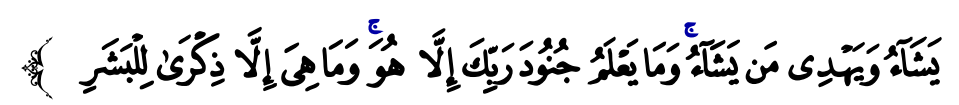

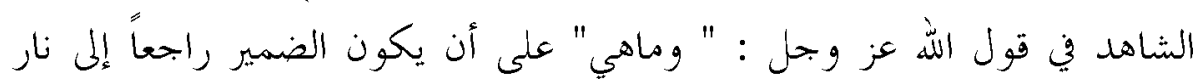

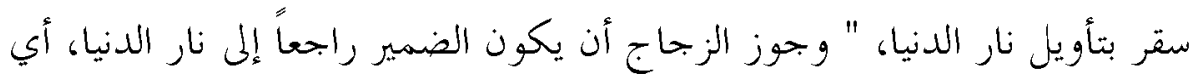

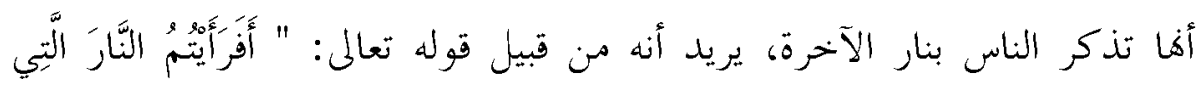

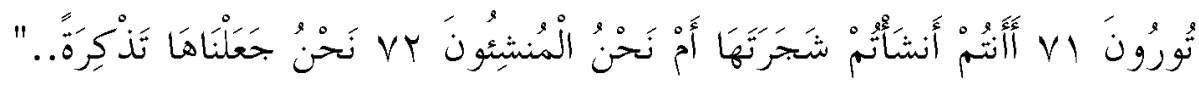

$$
\text { وفيه معسن الاستخدام"( م.1). }
$$

$$
\text { أع - سورة القيامة }
$$

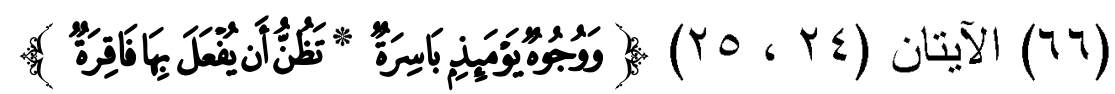
الشاهد في قول المولى عز وجل: (تظن) ففيها ضمير راجع إلى الوجوه .كعين الذوات (1,9). 


$$
\begin{aligned}
& \text { Y ع - سورة الإنسان } \\
& \text { (مثال إضافي) }
\end{aligned}
$$

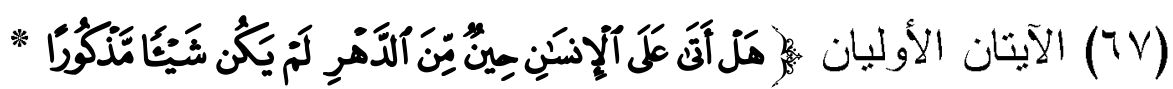

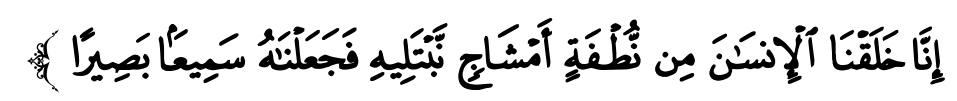

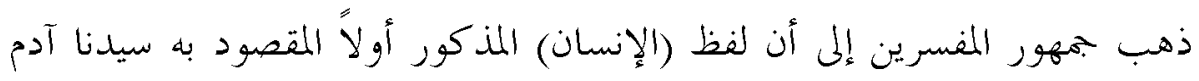

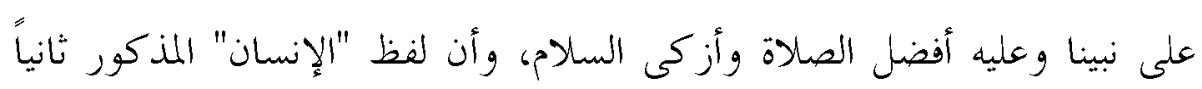

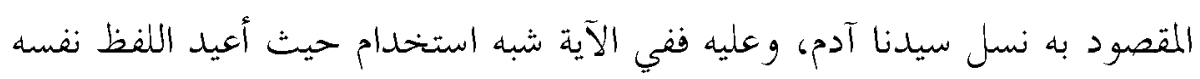

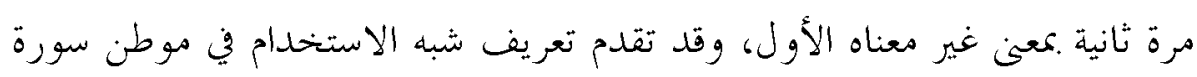
الأنفال.

\section{r

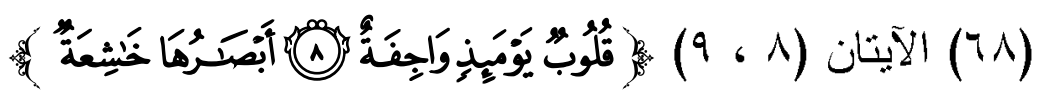

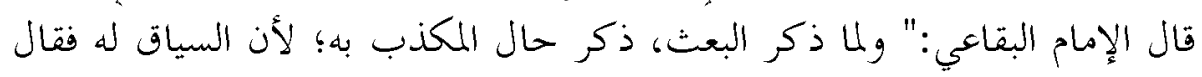

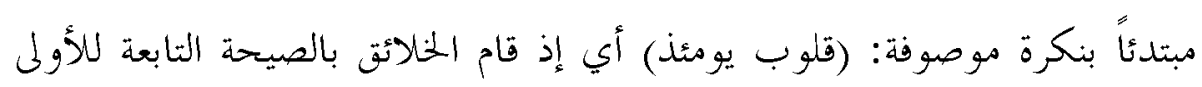

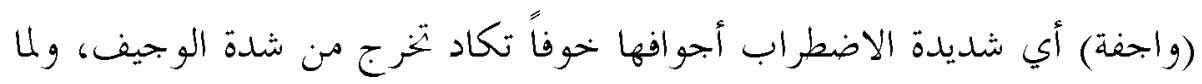

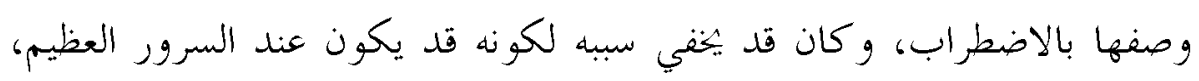

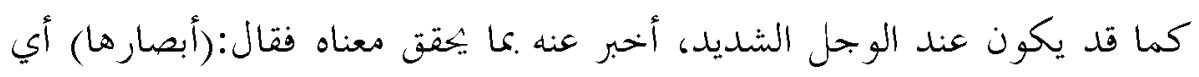

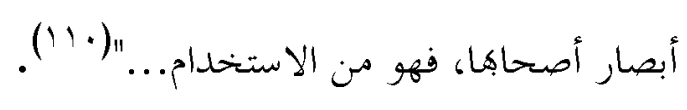

\section{ع ع - سورة الغاشية}

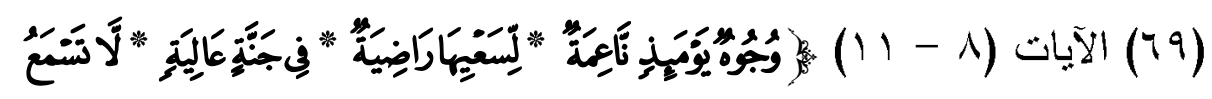

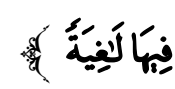

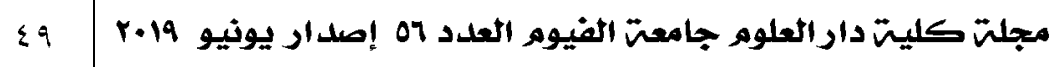


قال الألوسي:" (لا تسمع) خطاب لكل من يصلح للخطاب أو هو مسند إلى

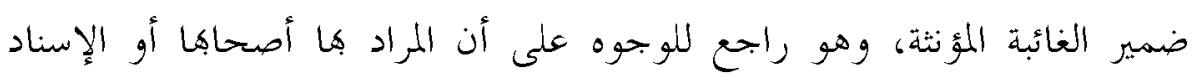
بحازي، و كذا يقال فيما قبل، وأشار بعض إلى أن في الآية صنعة الاستخدام

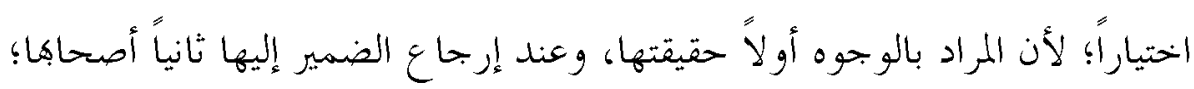

$$
\text { فهم الذين لا يسمعون فيها لاغيه..." (111). }
$$

\section{0 ع - سورة الشمس}

الآيات (V. )

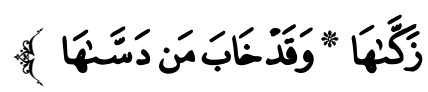

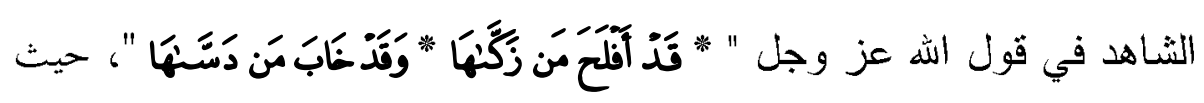

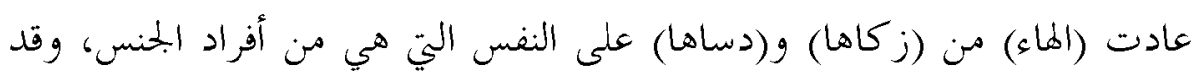
ذكرت قبل في قوله عز وجل "و نفس" بمعنى سيدنا آدم على أحد تفسيرين، يقول

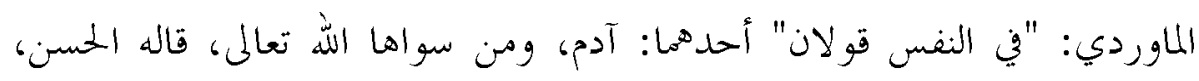
الثاني أها كل نفس وفي معنى سواها على هذا القول وجهان: أحدها: سوي بينهم في الصحة ...قاله ابن جريح.."(rا (I))، وقد نص على الاستخدام في هاتين الآيتين

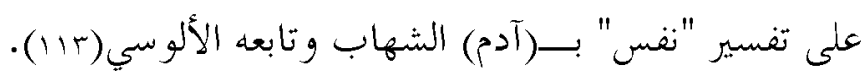

$$
\begin{aligned}
& \text { جع - سورة التين }
\end{aligned}
$$

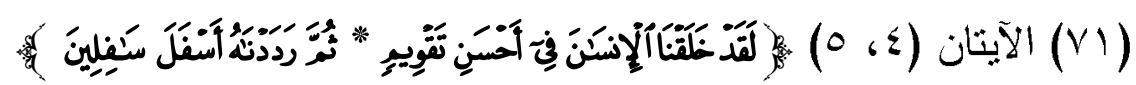

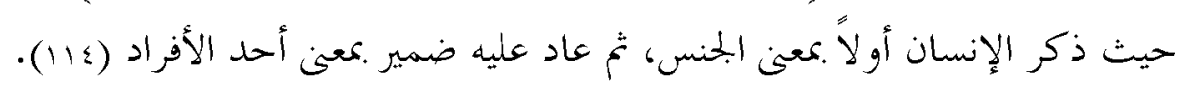

$$
\text { ع }
$$

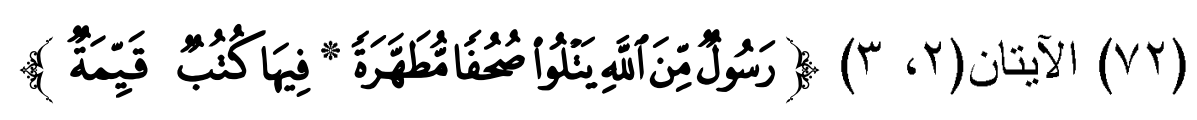




\section{مواطن ( الاستخدام ) البديعي في القرآن الكريم جمعاً ودراسة}

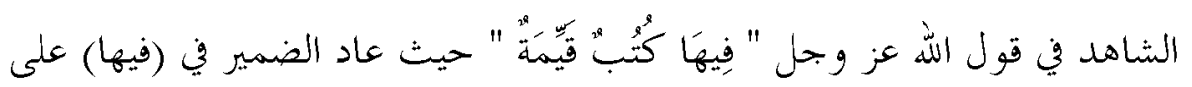
الصحف بمعناه الحقيقي، وقد ذكرت قبل أي الصحف بمعنى بمازي عن التلاوة بعالقة المحاز المرسل بعلاقة الخحلية وهي إطلاق المحل وإرادة الحال (110).

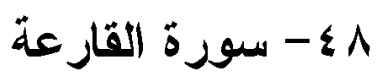

界)

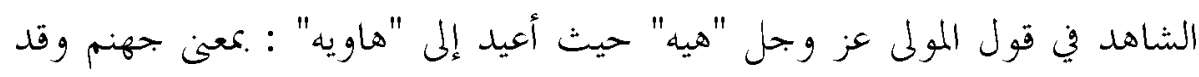
ذكرت قبل وصفاً لأمه إما بمعنى الأم الحقيقية أي الوالدة، وإما بمعنى أم الرأس أي إيل (1)

\section{ج ع - سورة الكوثز}

الاستخدام التقديري

الآية) (r) (V)

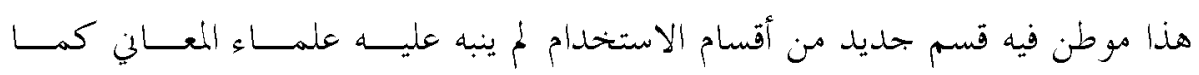

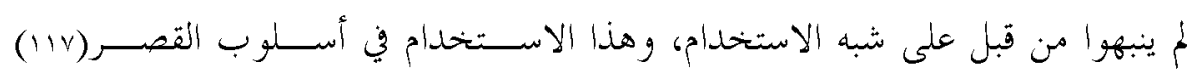

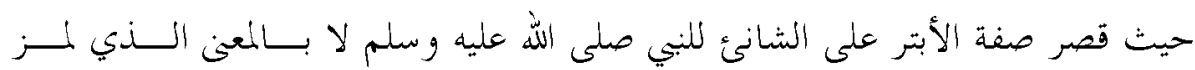

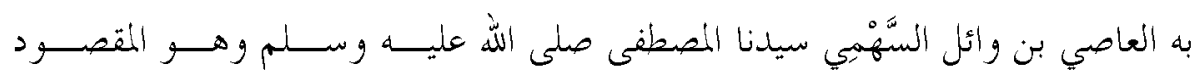

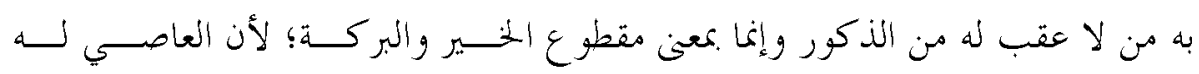

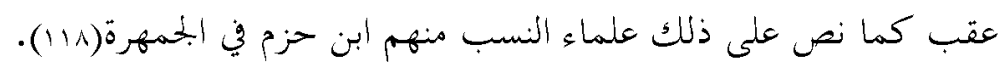




\section{مواطن ( الاستخدام ) البديعي في القرآن الكريم جمعاً ودراسة}

المسرد الإصماني للمواطن

\begin{tabular}{|c|c|c|c|c|c|}
\hline 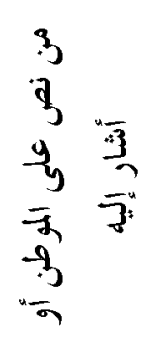 & $\begin{array}{l}\overline{\bar{x}_{3}} \\
\overline{\bar{u}}\end{array}$ & $\frac{2}{2}$ & $\overline{\mathrm{B}}^{*}$ & $\begin{array}{l}\frac{2}{2} \\
\overline{3} \\
0 \\
\bar{j} \\
\frac{1}{9}\end{array}$ & $\frac{1}{1}$ \\
\hline محرفة بن & مكية & 1 & 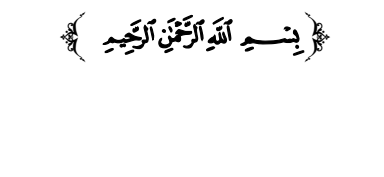 & 1 & الفاتحة \\
\hline الخفاجي & مدنية & ro & 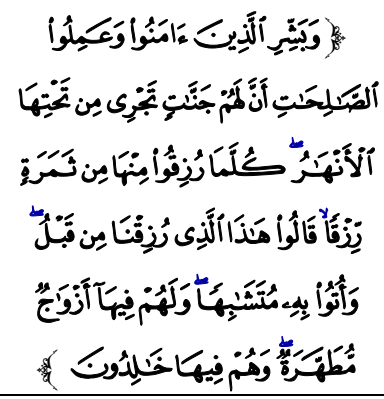 & $Y$ & البقرة \\
\hline الأكوسي & مدنية & ri & 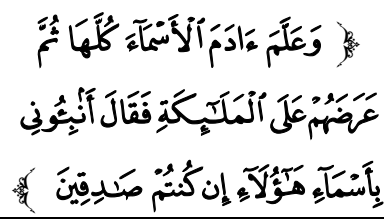 & & \\
\hline أبو السعود & مدنية & 110 & 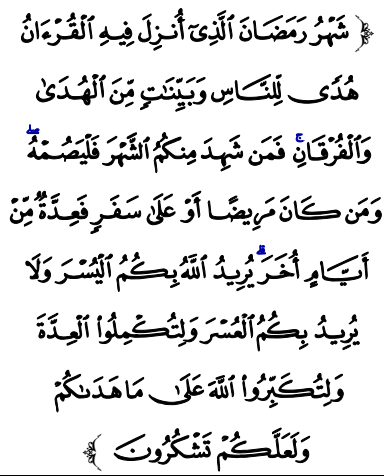 & & \\
\hline
\end{tabular}




\section{مواطن ( الاستخدام ) البديعي في القرآن الكريم جمعاً ودراسة}

\begin{tabular}{|c|c|c|c|c|c|c|}
\hline البسيلي & مدنية & Yol & 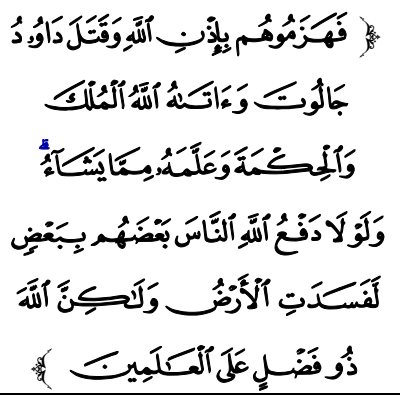 & & & 。 \\
\hline أبو حيان & مدنية & $|V|$ & 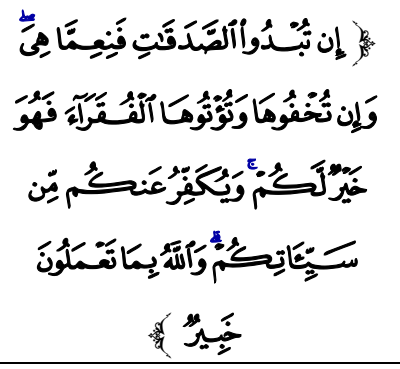 & & & 7 \\
\hline عابثنور & مدنية & 99 & 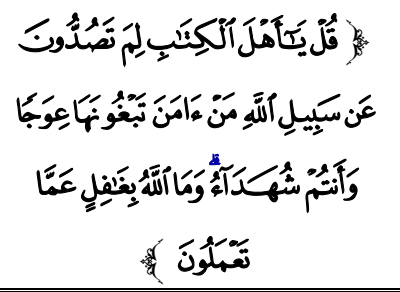 & $r$ & آل عمران & $v$ \\
\hline عاثشور & مدنبة & 110 & 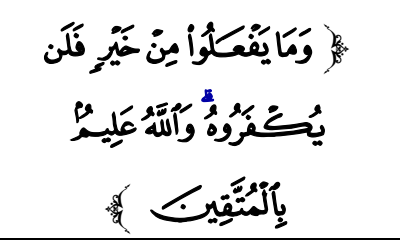 & $r$ & آل عمران & $\wedge$ \\
\hline عاشور & مدنبة & $1 \leqslant r$ & 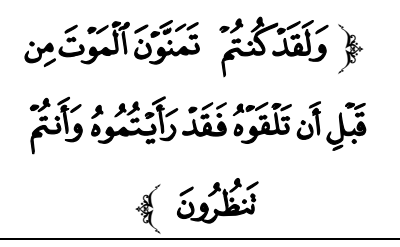 & & & 9 \\
\hline رشيد رضا & مدنية & 1 & 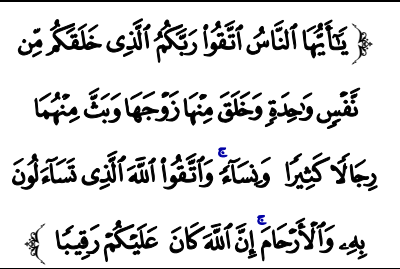 & $\varepsilon$ & النساء & 1. \\
\hline
\end{tabular}




\section{مواطن ( الاستخدام ) البديعي في القرآن الكريم جمعاً ودراسة}

\begin{tabular}{|c|c|c|c|c|}
\hline البسيلي & مدنية & $r$. & 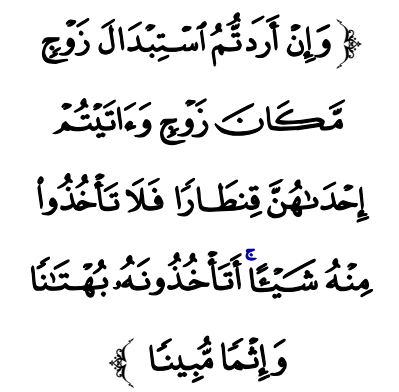 & 11 \\
\hline الزركشي & مدنية & $\leq r$ & 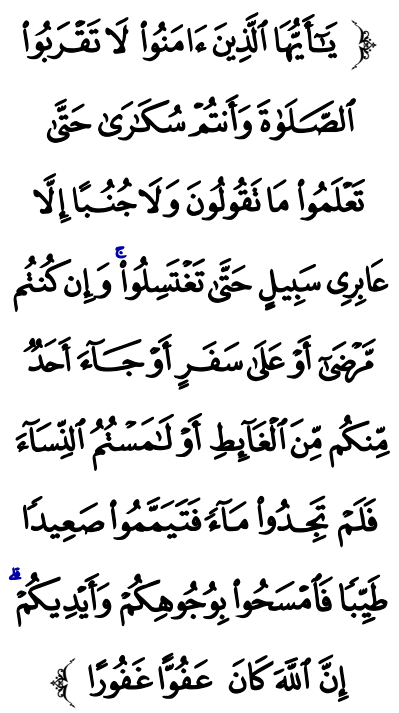 & ir \\
\hline أبو السعود & مدنية & $0 \varepsilon$ & 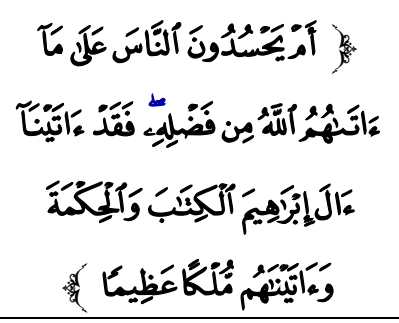 & ir \\
\hline البيضاوي & مدنية & Irr & 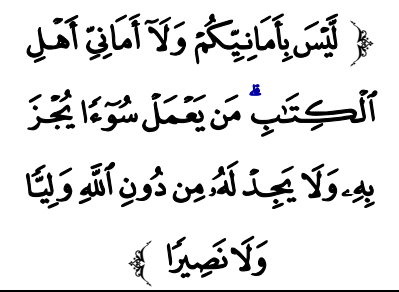 & 18 \\
\hline
\end{tabular}




\section{مواطن ( الاستخدام ) البديعي في القرآن الكريم جمعاً ودراسة}

\begin{tabular}{|c|c|c|c|c|c|c|}
\hline البقاعي & مدنية & ס 1 & 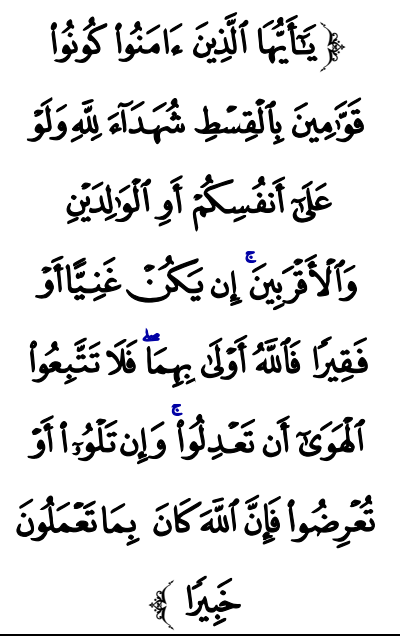 & & & 10 \\
\hline أصداوي & مدنية & 187 & 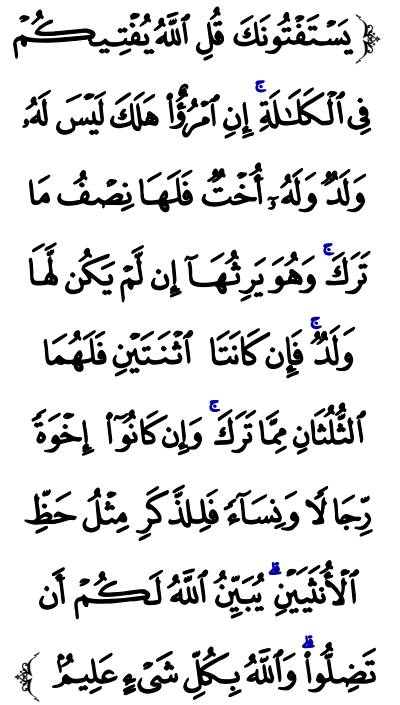 & & & 17 \\
\hline السبوطي & مدنبة & $\begin{array}{l}1.1 \\
1 . r\end{array}$ & 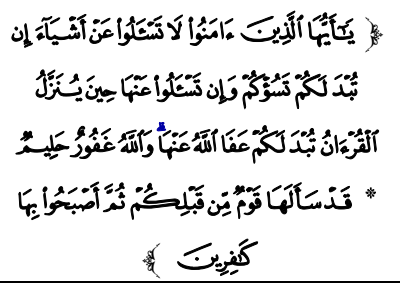 & • & المائدة & iv \\
\hline
\end{tabular}




\section{مواطن ( الاستخدام ) البديعي في القرآن الكريم جمعاً ودراسة}

\begin{tabular}{|c|c|c|c|c|c|c|}
\hline التفتاز اتي & مكية & $v$. & 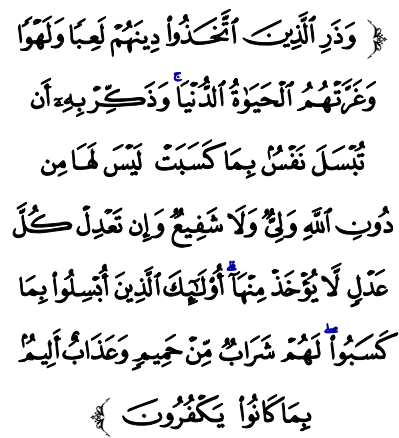 & 7 & الأنعام & 11 \\
\hline الخفاجي & مكية & 99 & 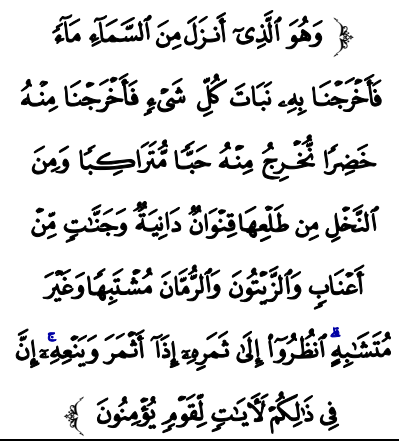 & & & 19 \\
\hline الألكوسي & مدنية & 194 & 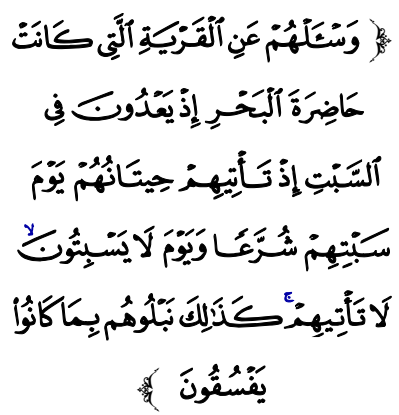 & $v$ & الأعراف & $r$. \\
\hline ابن عانشور & مكية & $\begin{array}{l}1119 \\
19 .\end{array}$ & 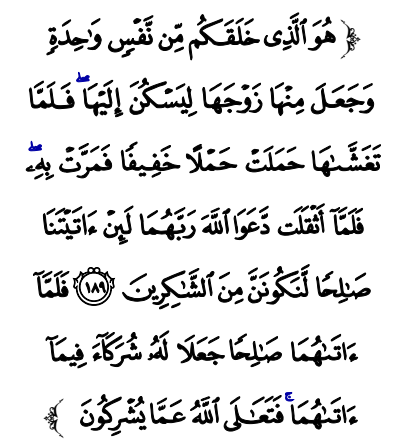 & & & YI \\
\hline
\end{tabular}




\section{مواطن ( الاستخدام ) البديعي في القرآن الكريم جمعاً ودراسة}

\begin{tabular}{|c|c|c|c|c|c|c|}
\hline إضحث شثال & مكية & rq & 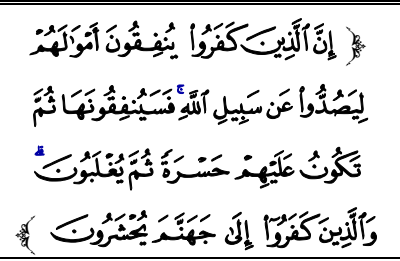 & $\wedge$ & الأنفال & Yr \\
\hline البقاعي & مدنية & $\varepsilon$. & 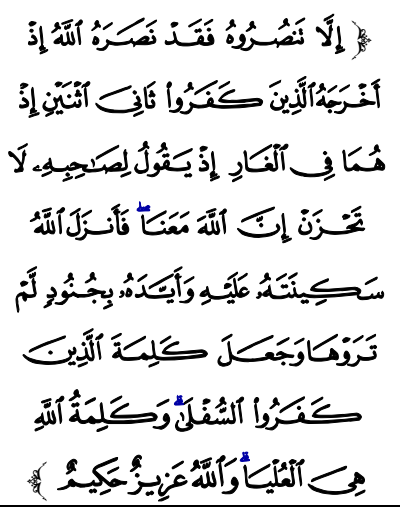 & 9 & التوبة & rt \\
\hline ابن عاثور & مدنية & IrT & 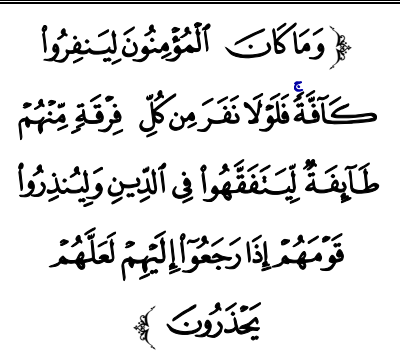 & $q$ & التوبة & $r \leq$ \\
\hline الخفاجي & مكية & Ar & 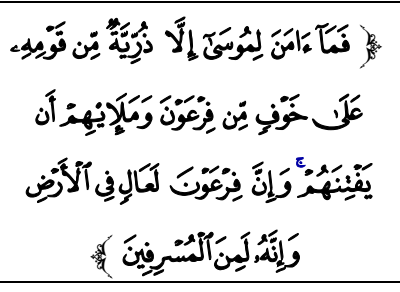 & 1. & يونس & ro \\
\hline الخفاجي & مكية & $\begin{array}{l}11 . \\
1.1\end{array}$ & 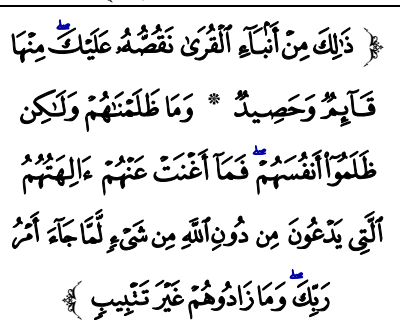 & 11 & هود & Y \\
\hline
\end{tabular}




\section{مواطن ( الاستخدام ) البديعي في القرآن الكريم جمعاً ودراسة}

\begin{tabular}{|c|c|c|c|c|c|c|}
\hline أبو السعود & مدنية & iv & 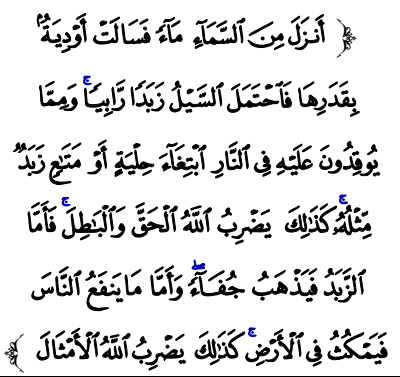 & ir & الزعد & rV \\
\hline صفي اللدين & مدنية & 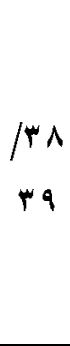 & 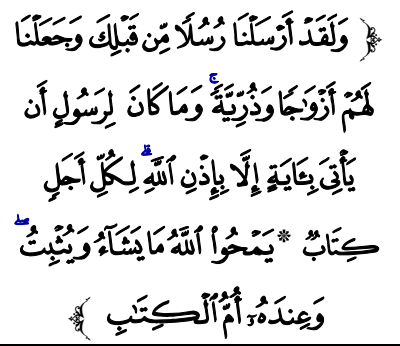 & & & rA \\
\hline الأكوسي & مكية & 19 & 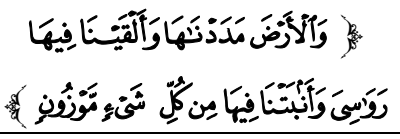 & ir & الحجر & rq \\
\hline البيوطي & مكية & 1 & 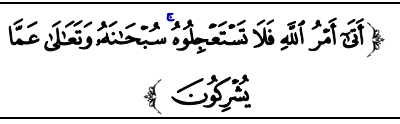 & $1 \varepsilon$ & النحل & r. \\
\hline السيوطي & مكية & $v_{1}$ & 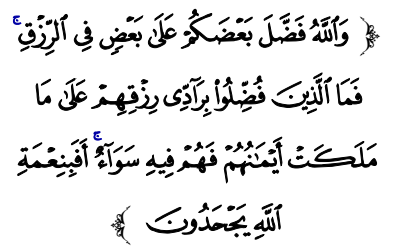 & & & ri \\
\hline الألوسي & مكية & $\Lambda_{0}$ & 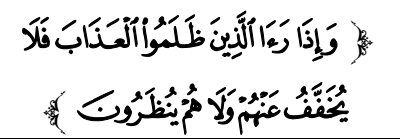 & & & ru \\
\hline صن خديق & مكية & $v$ & 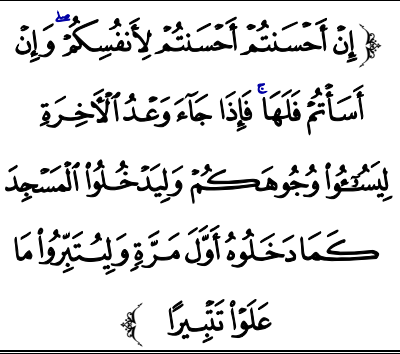 & 10 & الإسراء & $r r$ \\
\hline
\end{tabular}




\section{مواطن ( الاستخدام ) البديعي في القرآن الكريم جمعاً ودراسة}

\begin{tabular}{|c|c|c|c|c|c|c|}
\hline البقاعي & مدنية & $\begin{array}{l}/ \vee \wedge \\
\vee q\end{array}$ & 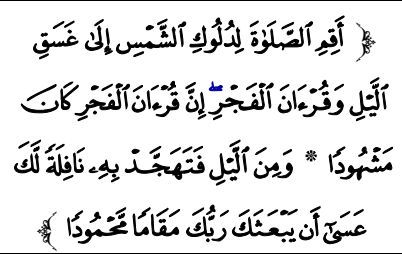 & & & $r \varepsilon$ \\
\hline التزمثري & مكية & 1.1 & 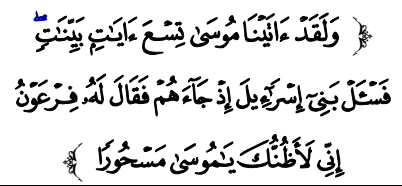 & & & ro \\
\hline الثخهاب & مكية & 19 & 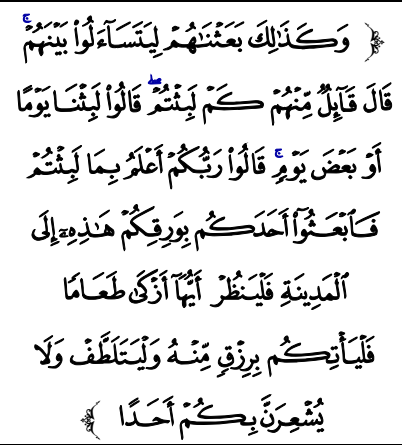 & 18 & الكهف & rq \\
\hline الشهاب & مكية & $\begin{array}{l}11 \ldots \\
1.1\end{array}$ & 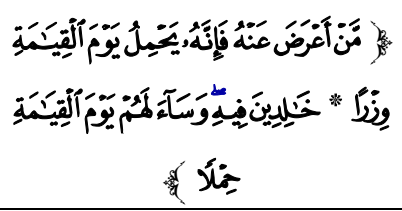 & iv & طه & rV \\
\hline |الثهاب & مكية & $1 . \varepsilon$ & 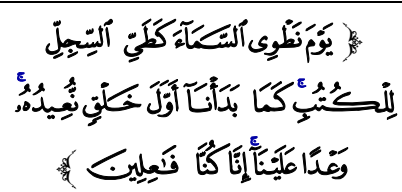 & in & الأنبياء & $r \wedge$ \\
\hline الثخهاب & مكية & 00 & 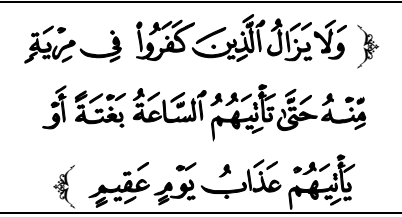 & 19 & الحج & rq \\
\hline الززركثي & مكية & $\begin{array}{l}/ r \\
\text { Ir }\end{array}$ & 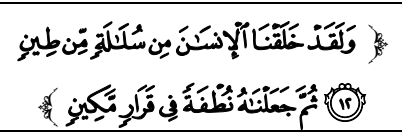 & $r$. & المؤمنون & $\varepsilon$. \\
\hline البقاعي & مكية & $r$ & 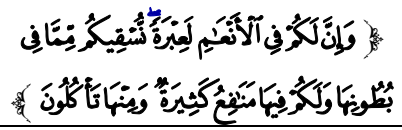 & & & $\leqslant 1$ \\
\hline الألوسي & مكية & $Y Y$ & 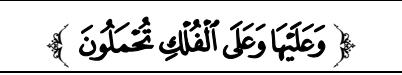 & & & $\varepsilon r$ \\
\hline
\end{tabular}


مواطن ( الاستخدام ) البديعي في القرآن الكريم جمعاً ودراسة

\begin{tabular}{|c|c|c|c|c|c|c|}
\hline الأكوسي & مكية & $\begin{array}{l}\text { por } \\
\text { or }\end{array}$ & 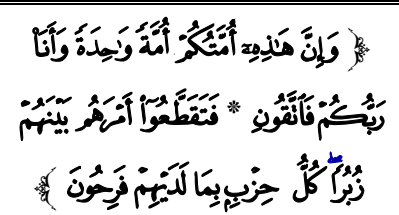 & & & $\varepsilon r$ \\
\hline الألوسي & مكية & Q & 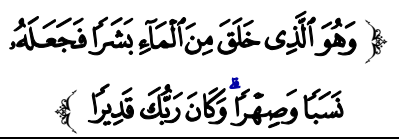 & r & الفرقان & $\varepsilon \varepsilon$ \\
\hline ابن عاشور & مكية & $\begin{array}{l}\text { /OV } \\
\Delta 9\end{array}$ & 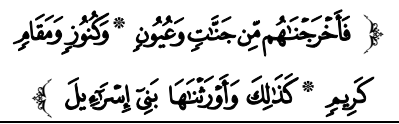 & $r$ & الشعراء & $\leq 0$ \\
\hline ابن باديس & ككية & $\begin{array}{l}\text { Krt } \\
\text { Tr }\end{array}$ & 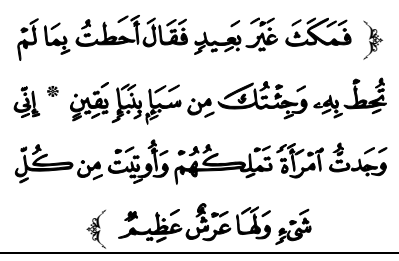 & $r r$ & النمل & $\leqslant 4$ \\
\hline البقاعي & مكية & $\wedge \wedge$ & 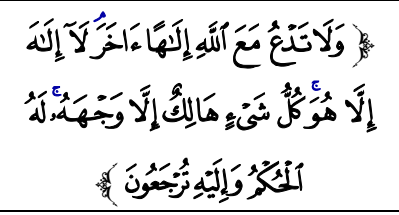 & $r \varepsilon$ & القصص & $\varepsilon v$ \\
\hline الألوسي & مكية & $r r$ & 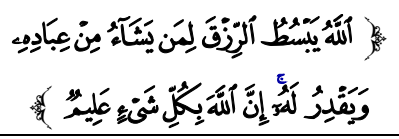 & ro & العنكبوت & $\leqslant \wedge$ \\
\hline | دحيي الاين & مكية & $\begin{array}{l}+11 \\
\text { TV }\end{array}$ & 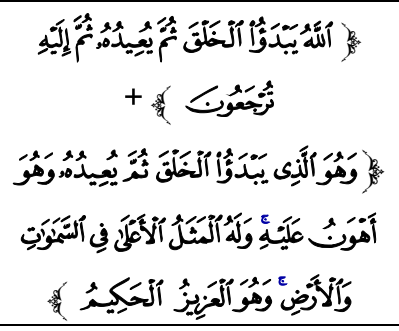 & rq & الزوم & $\leqslant 9$ \\
\hline البقاعي & مكية & 0 & 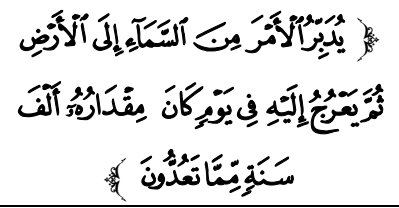 & rv & السجدة & ه. \\
\hline جمال الاين & مكية & Yr & 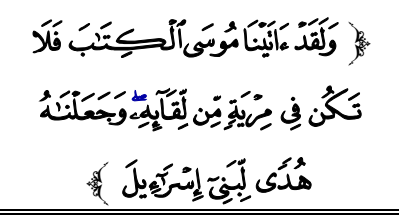 & & & 01 \\
\hline
\end{tabular}




\section{مواطن ( الاستخدام ) البديعي في القرآن الكريم جمعاً ودراسة}

\begin{tabular}{|c|c|c|c|c|c|c|}
\hline ابن عاثور & مدنية & $V Y$ & 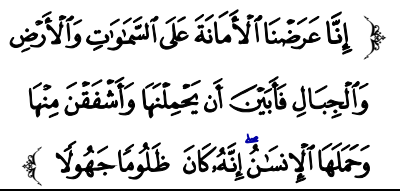 & YA & الأحزاب & Or \\
\hline الأكوسي & مكية & 10 & 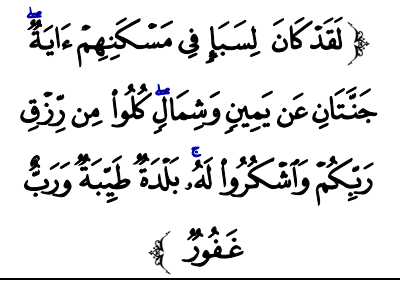 & rq & سبأ & ro \\
\hline البقاعي & مكية & 11 & 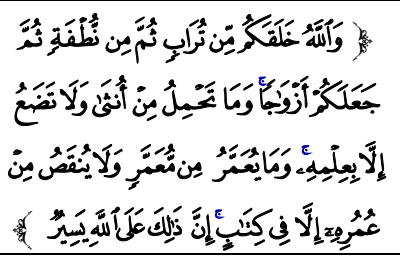 & $r$. & فاطر & $0\}$ \\
\hline المصري & مكية & $\vee \wedge$ & 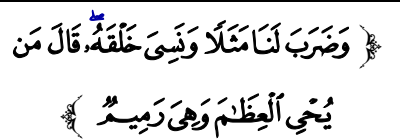 & r & بس & $\Delta \theta$ \\
\hline مثال إضافي عاشور & مكية & $r$ & 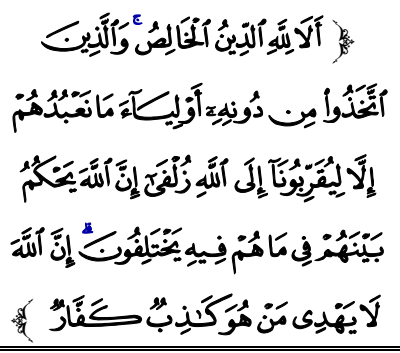 & rt & الزمر & 84 \\
\hline الألوسي & مكية & $\leqslant 9$ & 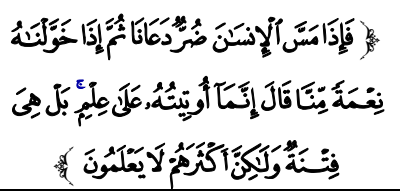 & rr & الزمر & ov \\
\hline الألوسي & مكية & 9 & 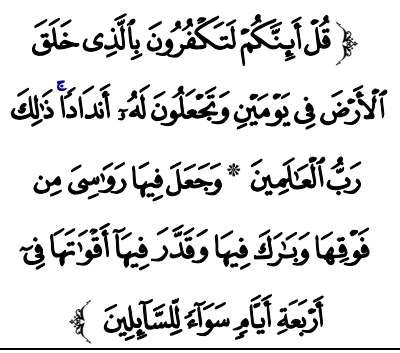 & $r r$ & فصلت & $\Delta \wedge$ \\
\hline ابن عاثنور & مكية & rA & 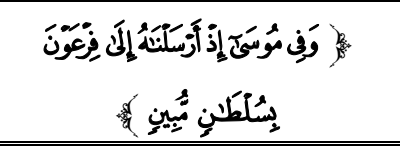 & $r \leqslant$ & الذاريات & ه \\
\hline
\end{tabular}

مجلت كليت دار العلوه جامعت الفيوهر العدد Or إصلدار يونيو 19 r r r 


\section{مواطن ( الاستخدام ) البديعي في القرآن الكريم جمعاً ودراسة}

\begin{tabular}{|c|c|c|c|c|c|c|}
\hline البقاعي & مكية & ס & 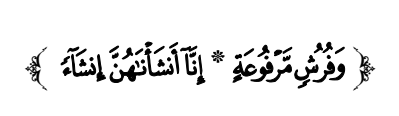 & ro & الثو اقعة & 7. \\
\hline ابن عاثورد & مدنية & 19 & 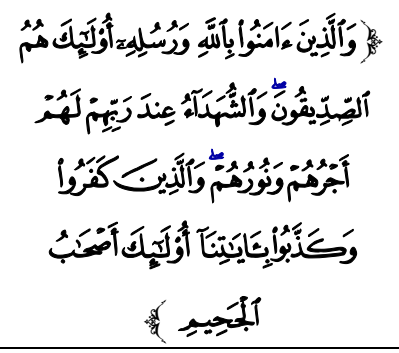 & $\mathrm{m}$ & الحديد & 71 \\
\hline اسماعيل & مدنية & Ir & 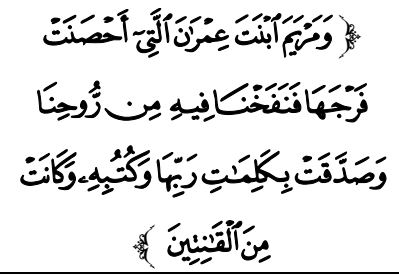 & rv & التحريم & $7 r$ \\
\hline إضافي مثال & مكية & • & 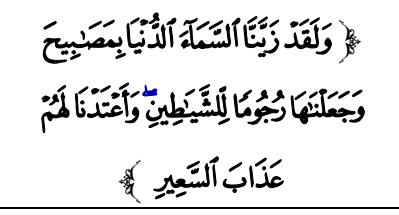 & ra & المثلك & $8 r$ \\
\hline ابن عاثشور & مكية & $v$ & 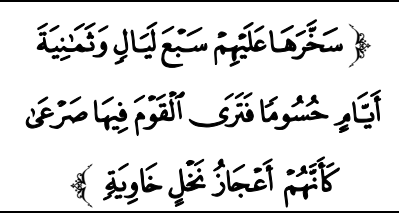 & rq & الحاقة & $7 \leq$ \\
\hline ابن عاثورد & مكية & $r$ & 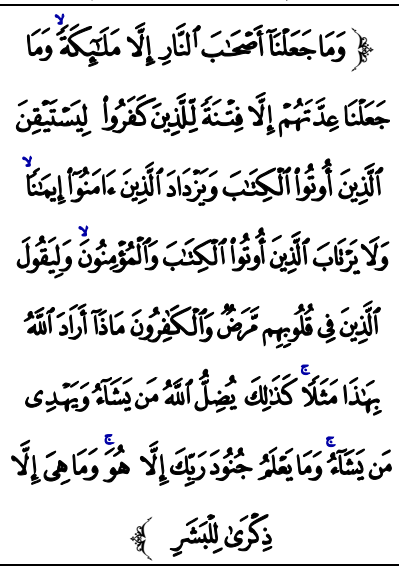 & $\varepsilon$. & المدثر & 70 \\
\hline ابن عاثشور & مكية & $\begin{array}{l}\text { rys } \\
\text { ro }\end{array}$ & 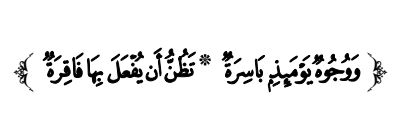 & \&1 & القبامة & 47 \\
\hline
\end{tabular}




\section{ـــــــ مواطن ( الاستخدام ) البديعي في القرآن الكريم جمعاً ودراسة}

\begin{tabular}{|c|c|c|c|c|c|c|}
\hline إضافث مثال & مدنية & 1 & 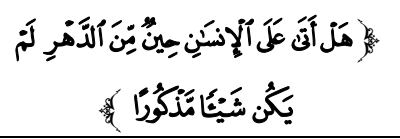 & $\varepsilon r$ & الإنسان & $7 v$ \\
\hline البقاعي & مكية & $9 / 1$ & 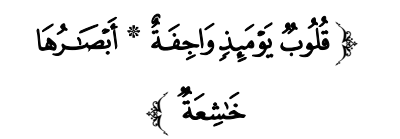 & $\varepsilon r$ & الناز عات & 91 \\
\hline الألوسي & مكية & $\begin{array}{l}-1 \\
11\end{array}$ & 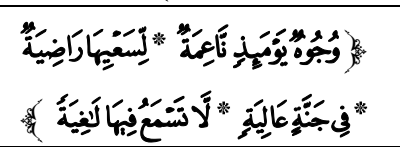 & $\{\leqslant$ & الفاشية & 79 \\
\hline الثهاب & مكية & $\begin{array}{l}-v \\
1 .\end{array}$ & 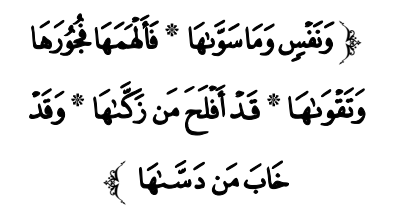 & \&o & الثمس & $v$. \\
\hline أحمد & مكية & $0 / \leqslant$ & 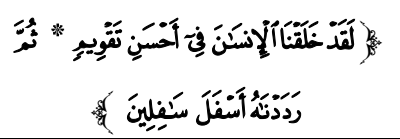 & $\leq 4$ & التين & VI \\
\hline الأكوسي & مدنبة & $r / r$ & 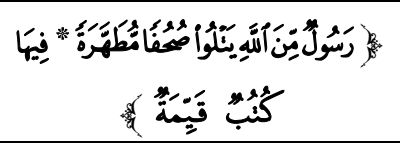 & $\{v$ & الليينة & VY \\
\hline ابن عاثور & مكية & 9 & 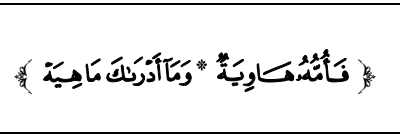 & $\{A$ & القارعة & $V_{T}$ \\
\hline مثال إضاف عاشور & مكية & $r$ & 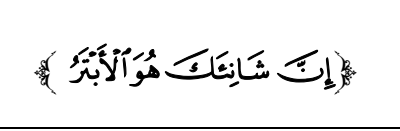 & $\varepsilon 9$ & الكوثر & $v \varepsilon$ \\
\hline
\end{tabular}

\section{الخاتمة}

و بعد فهذه أهم نتائج ما توصل إليه البحث:

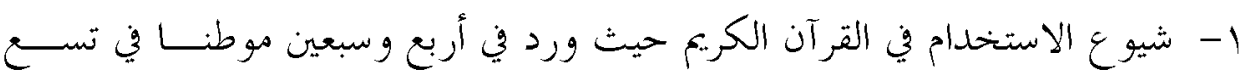

وأربعين سورة بداية من الفاتحة حتى سورة الكوثر و كان أكثر السور وروداً سورة

النساء جاء فيها سبع مواطن تليها سورة البقرة وفيها خمس مواطن ثم تليها ســـورة

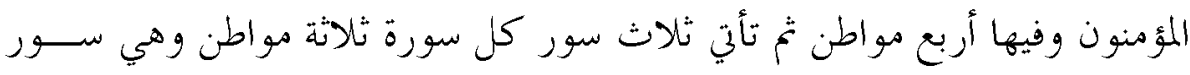

آل عمران والنحل والإسراء ثم بعد ذلك تأتي ست سور قد جاء في كـلـل ســورة 


\section{مواطن ( الاستخدام ) البديعي في القرآن الكريم جمعاً ودراسة}

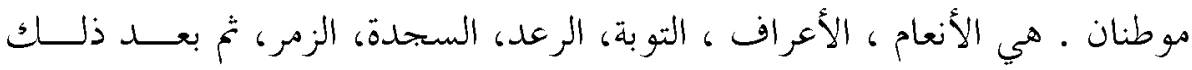
باقي السور وهي سبع وثلاثون قد جاء في كل سورة موطن ·

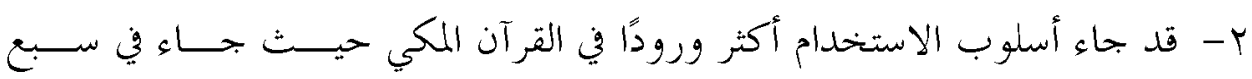
وأربعين موطنا على حين جاء في القرآن المدني سبع وعشرين موطنا .

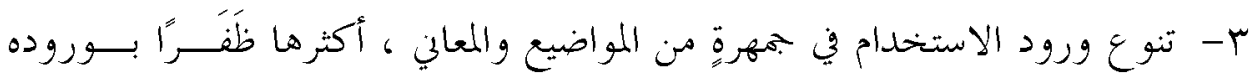

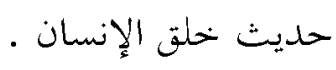

ـ- أهمية هذا الأسلوب من الكلام لدرجة أنه قد يكون ضرورة بيانية حينما يُنْجَاً إليه لتأويل ما يشكل من المعاني كالحديث عن عصمة الأنبياء أو الوقائع التاريخية وذلك آنك

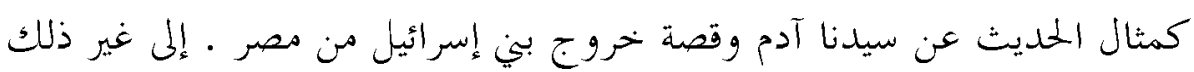

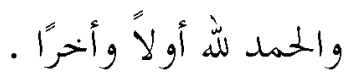

\section{قائمة المصادر والمراجع}

\section{أولاك: القرآن الكريم

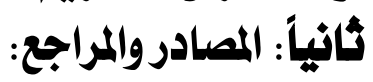

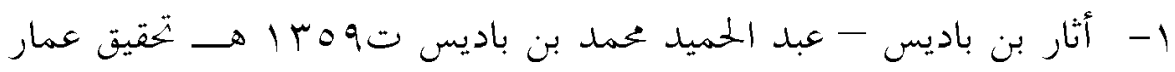

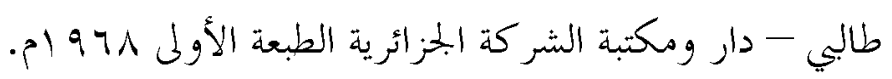

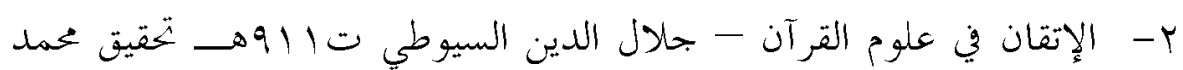

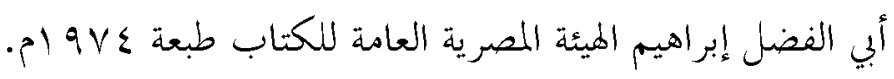

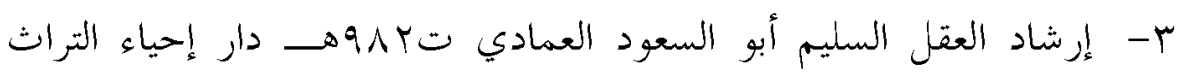
• العربي

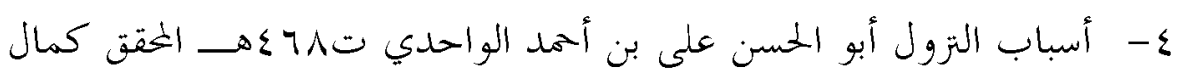

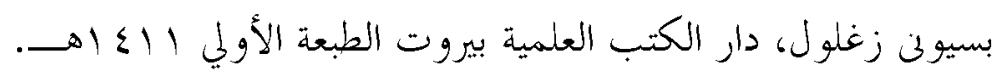
ه- الأصلان في علو القرآن محمد عبد المنعم القيعي ، الطبعة الثانية 997 أم. 
مواطن ( الاستخدام ) البديعي في القرآن الكريم جمعاً ودراسة

צ- إعراب القرآن وبيانه، ميي الدين درويش تب. أهــ، دار الإرشاد

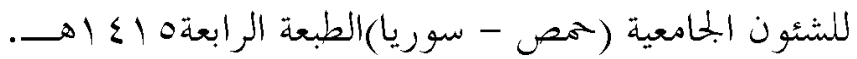

- V الإيضاح ع في علوم البلاغة ، محمد بن عبد الرحمن، الخطيب القزويني

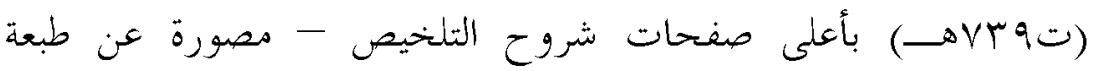

$\cdot 6194 \mathrm{r}$

ᄉ- البحر الرائق شرح كتر الدقائق (فقه حنفي) زين الدين بن إبراهيم ابن بنيم المصري ت • V9هـــ ، دار الكتاب الإسلامي الطبعة الثانية.

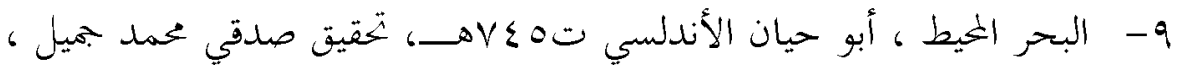

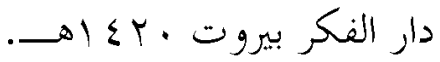

• ا- البديع في نقد الشعر، أسامة بن منقذ، تحقيق د/ أحمد أحمد بدوي، د/ حامد

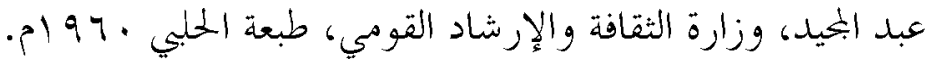

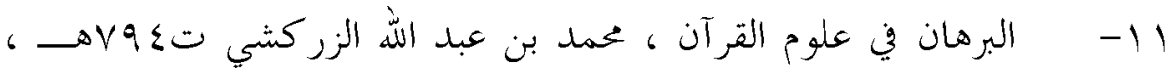

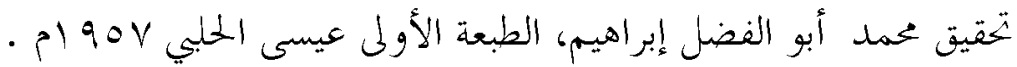

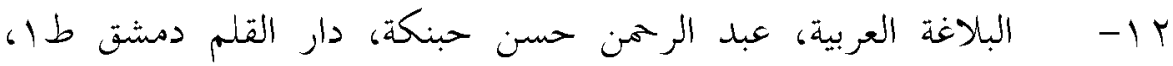

$$
\text { . } 1997
$$

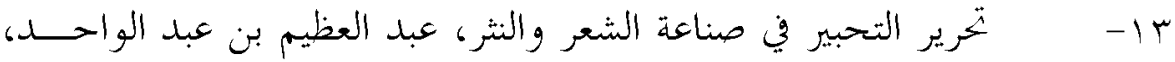

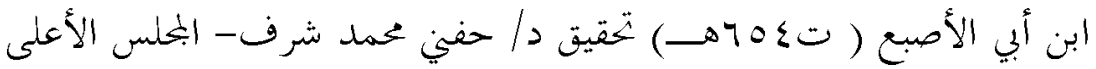

للشئون الإسلامية - بلجنة إحياء التراث العربي.

ـ ا- التحرير والتنوير، الطاهر بن عاشور ، الدار التونسية - تونس-

$$
\text { . }) 9 \wedge
$$

ه - - تفسير القرآن الحكيم المشتهر باسم تفسير المنار، محمد رشيد رضا،

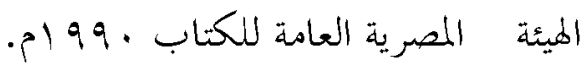

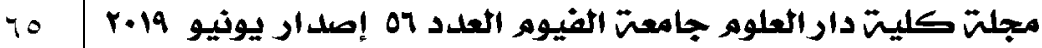




\section{مواطن ( الاستخدام ) البديعي في القرآن الكريم جمعاً ودراسة}

17- التقييد الكبير، أحمد بن محمد الباسيلي ت.برهــ، تحقيق د/ عبد الله

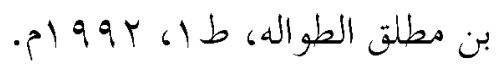
IV عباس زكي، خرج الأحاديث د/ على جمعه.

1 ا- - جمهرة أنساب العرب، ابن حزم الأندلسي، تعقيق عبد السلام هارون،

$$
\text { دار المعارف }
$$

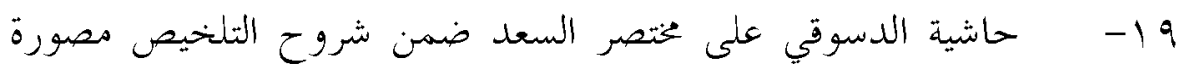
عن الميمنية.

•r-

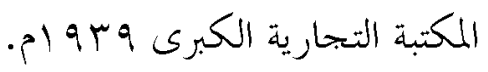

ا Y- حسن التوسل إلى صناعة الترسل ، شهاب الدين ممود بن سليمان

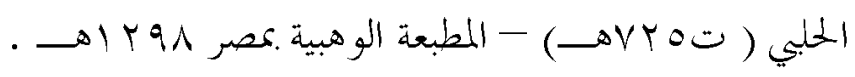

Y Y- الحضارات القديمة في القرآن الكريم، مقال للأستاذ عبد المتعال الصعيدي، بحلة الرسالة ، العدد 99 ؟ـ.

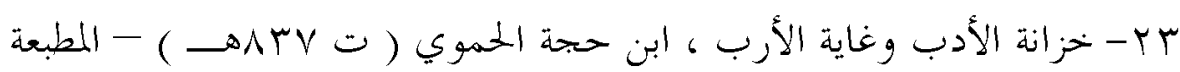

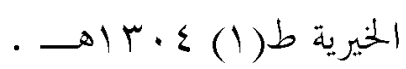

ع - - الدر المصون في علوم الكتاب الملكنون، السمين الحلبي ت د/ أحمد محمد الحزراط، دار القلم - دمشق.

هץ- ديوان البحتري تحقيق حسن كامل الصيرفي - دار المعارف - القاهرة $\cdot 619 \mathrm{VP}-$

צY- روح البيان في تفسير القرآن ، إسماعيل حقي تV I I اهــ، دار الفكر

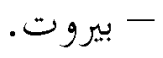




\section{مواطن ( الاستخدام ) البديعي في القرآن الكريم جمعاً ودراسة}

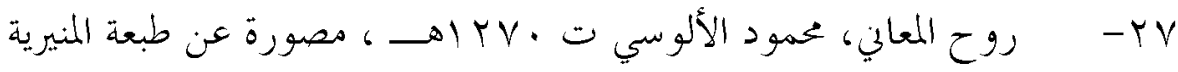
وتقع في · ب جزءاً، طبعة تحقيق على عبد المادي عطية ، دار الكتب العلمية،

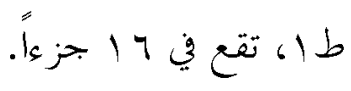

^r - ريحانة الألبا، الشهاب الخفاجي ت/ عبد الفتاح الحلو، عيسى الحلبي $.9197 \mathrm{~V}$

9 - - السراج المنير في الإعانة على معرفة بعض معاني كلام ربنا الحكيم

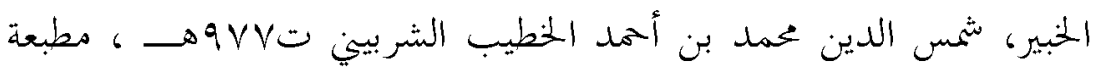

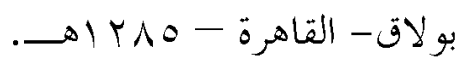

•r- شرح عقود الجمان ، جلال الدين السيوطي( ت 911هـ) هكامش شرح عقود الجمان للمرشدي، الطبعة الثانية 900 ام مصطفى الباب الحببي.

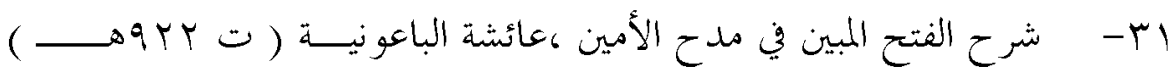

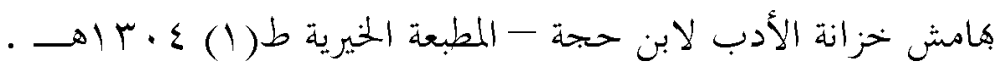

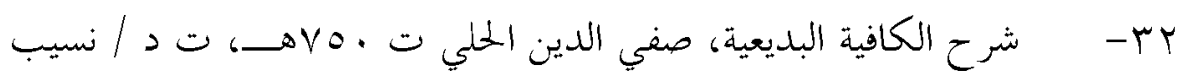
نشاوي، دار صادر طب مبك.

بr- شرح غختصر خليل (فقه مالكي) محمد بن عبد الله الخرشي

$$
\text { ت1 + إهـــ دار الغد - بيروت. }
$$

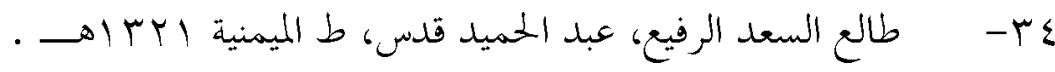
هـ- طراز الحلة وشفاء الغلة، شهاب الدين أحمد بن يوسف الغرناطي ت

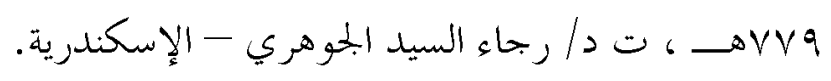

بr- طراز البجالس ، الشهاب الحفاجي، مكتبة مصطفى تاج الكتبي بطنطا.

- ع مروس الأفراح في شرح تلخيص المفتاح ( ضمن شروح التخخيص ) :

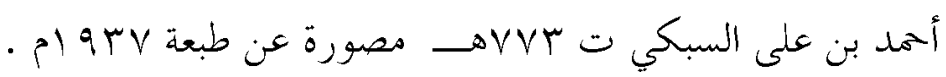




\section{مواطن ( الاستخدام ) البديعي في القرآن الكريم جمعاً ودراسة}

ᄉr- عناية القاضي و كفاية الراضي(حاشية الشهاب المفاجي على تفسير البيضاوي) مصورة عن طبعة قديمة.

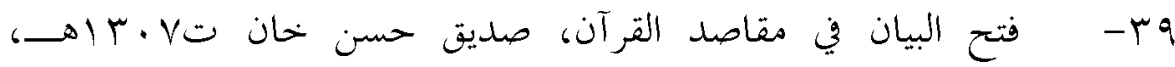

$$
\text { المكتبة العصرية (صيدا - بيروت) بو } 99 \text { ام. }
$$

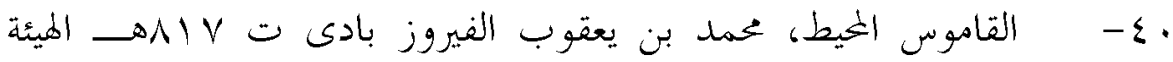
المصرية العامة للكتاب (999 (9) مصورة عن الطبعة الثالثة الأميرية

$$
\text { - } \rightarrow r+1
$$

إ- - الكشاف عن حقائق غوامض التنزيل ، أبو القاسم محمود بن عمر

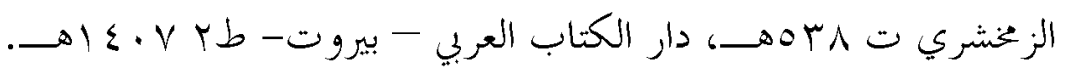

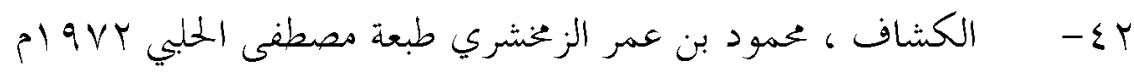

r

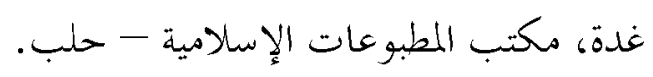

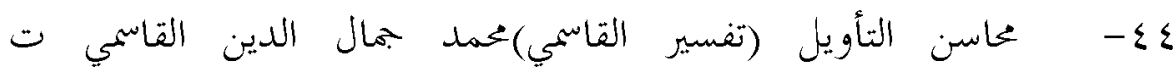

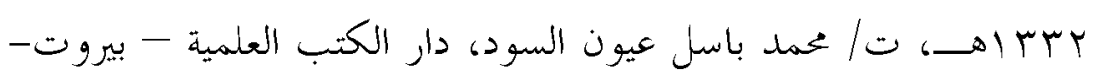

$$
\rightarrow \leqslant 1 \wedge 1 b
$$

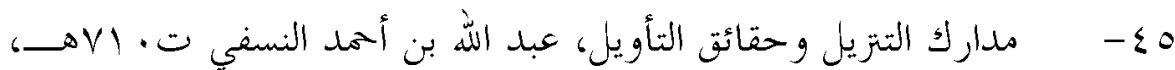

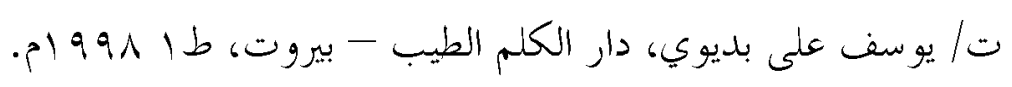

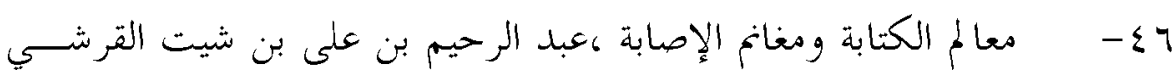

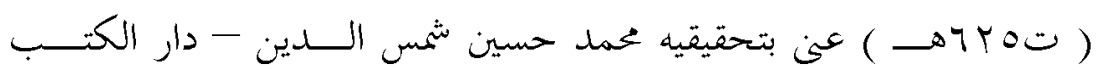

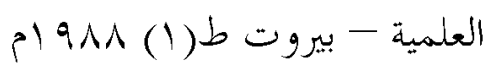

§V - معترك الأقران في إعجاز القرآن، جالال الدين السيوطي، دار الكتب

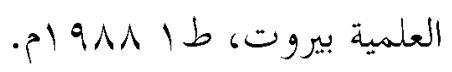




\section{مواطن ( الاستخدام ) البديعي في القرآن الكريم جمعاً ودراسة}

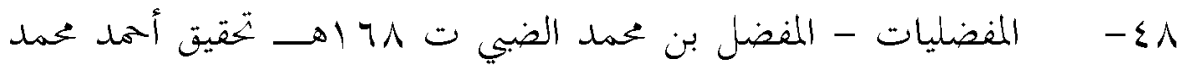
شاكر وعبد السلام محمد هارون - دار المعارف - القاهرة - الطبعة

\section{السادسة}

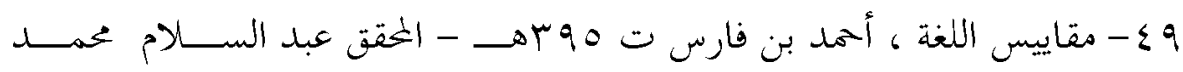

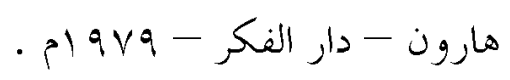

•- مواهب الفتاح ( ضمن شروح التلخيص ) ابن يعقوب المغربي مصورة عن - مبعة Prv

1- - لظم الدرر في تناسب الآيات والسور، الإمام البقاعي، دار الكتاب الإسلامي مصورة عن طبعة الهند.

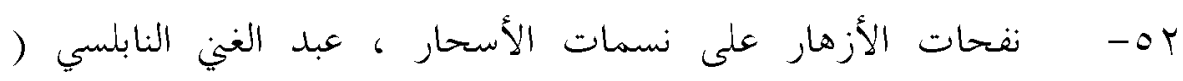

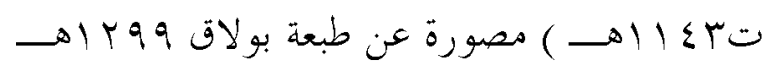

ror - مكت وتنبيهات في تفسير القرآن البخيد، أبو العباس البسيلي التونسي

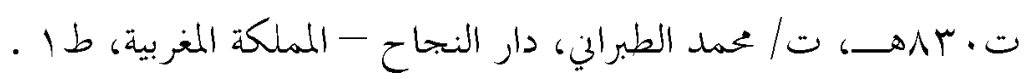

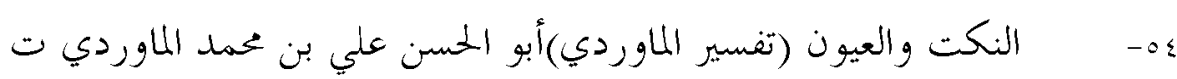

$$
\text { . كهــ، دار الكتب العنمية - بيروت - لبنان. }
$$

\section{الهوامش والإحالات}

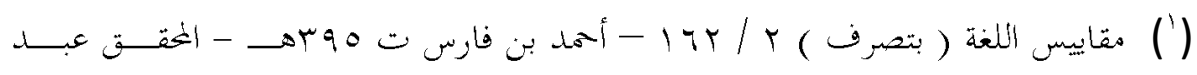

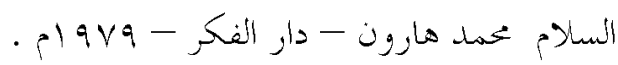

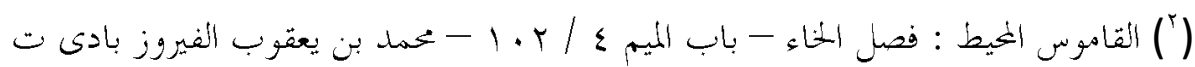

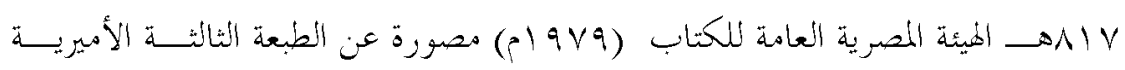

$$
\rightarrow 1+\cdot 1
$$




\section{مواطن ( الاستخدام ) البديعي في القرآن الكريم جمعاً ودراسة}

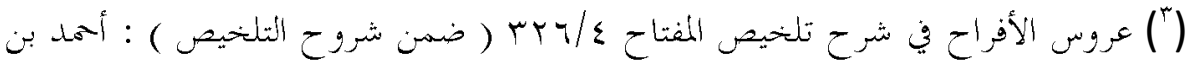

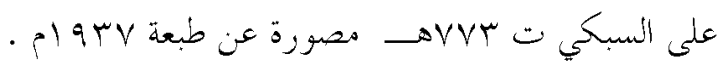

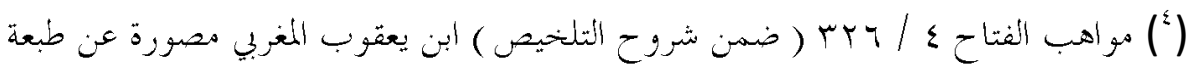
$\cdot 69 \mathrm{rr}$

(0) رواية الديوان : ( والنازلية ... وقلوب ) ، والبيت من قصيدة يمدح هما اسـحاق بــن

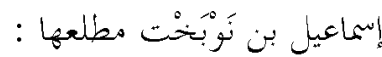

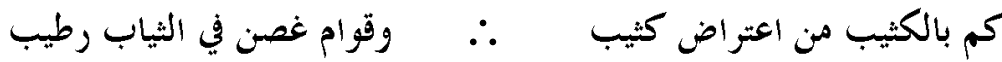

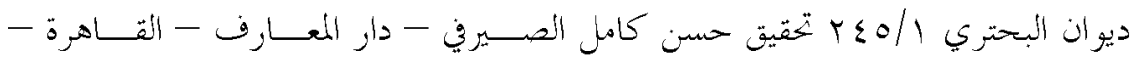

$$
\text { . } 19 \mathrm{VY}
$$

(T) قائله : معاوية بن مالك، من شعر اء المفضليات، والبيت من المفضلية هـ ـ 1 ـ المفضليات /

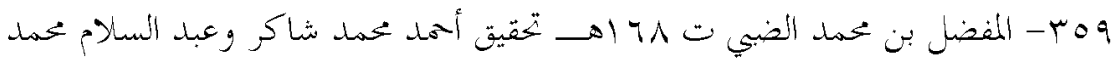

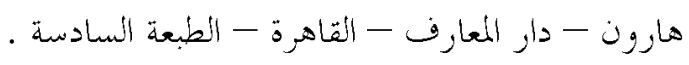

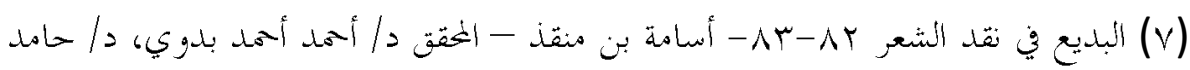

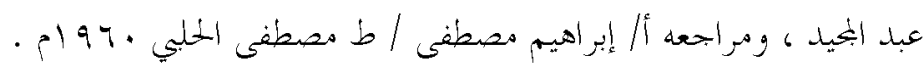

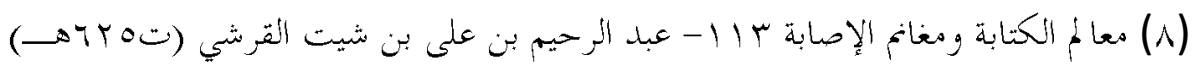

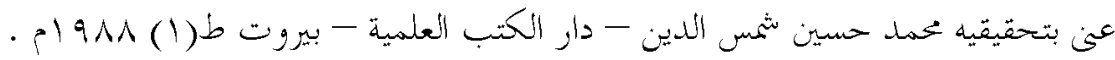

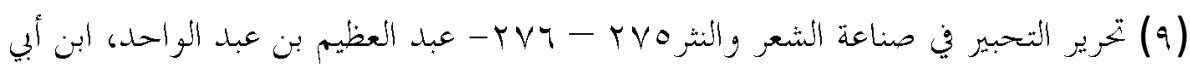

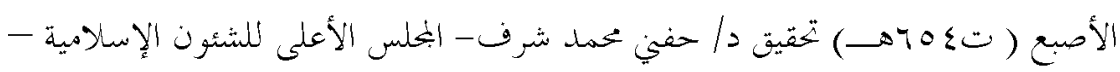
لجنة إحياء التراث العربي.

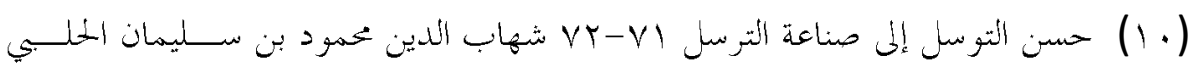

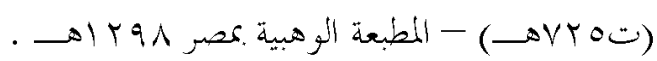

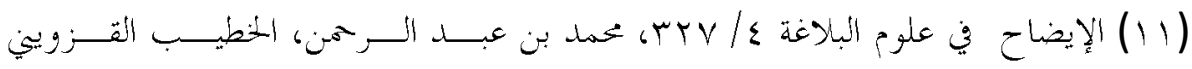

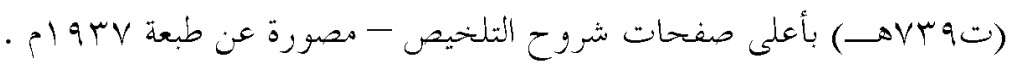

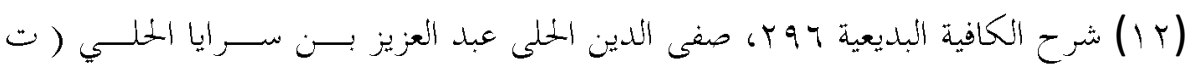

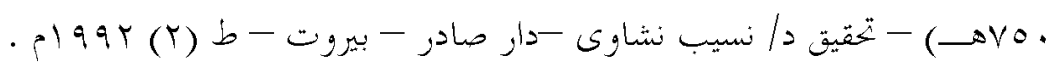




$$
\text { : ينظ) }
$$

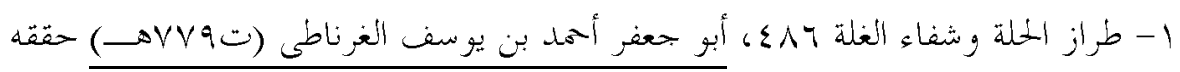

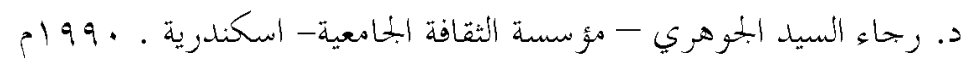

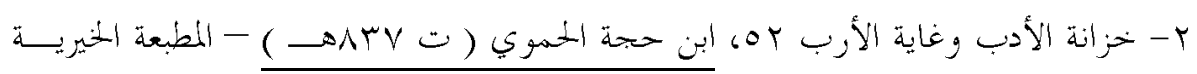

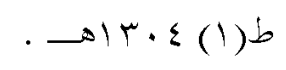

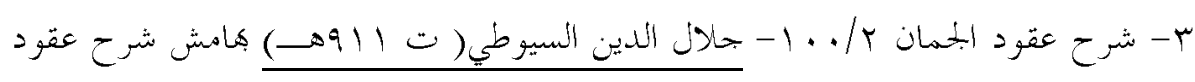

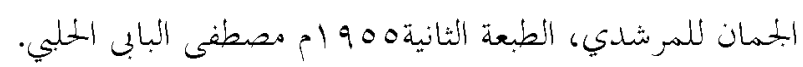

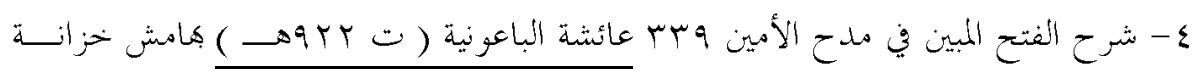

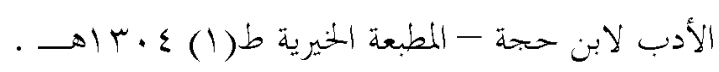

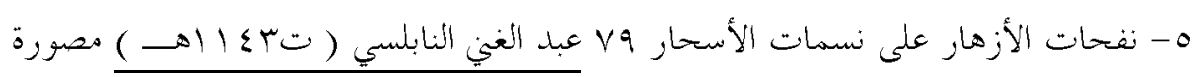

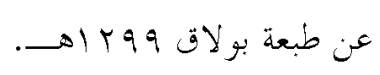

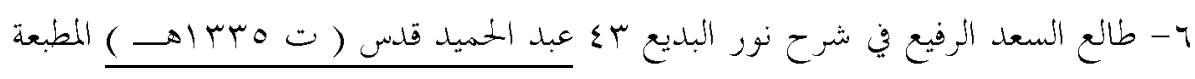

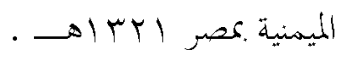

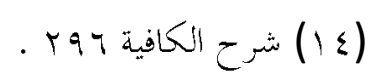

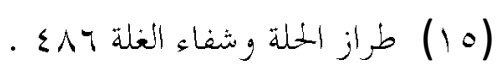

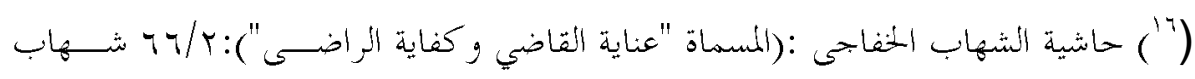

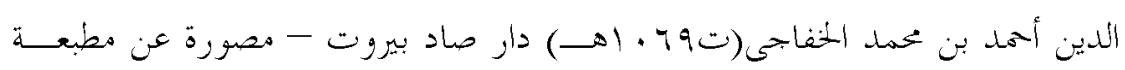

قديمة.

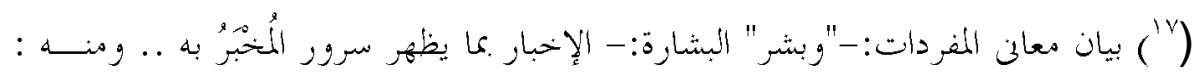

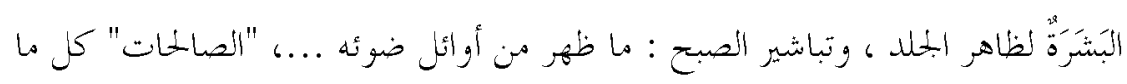

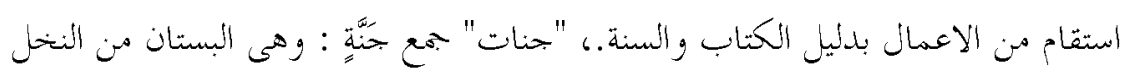

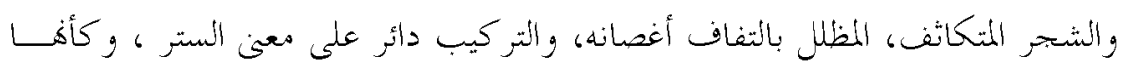

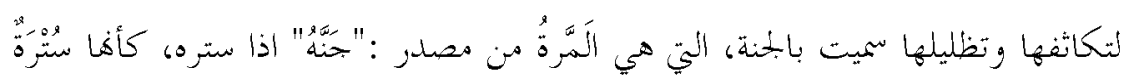

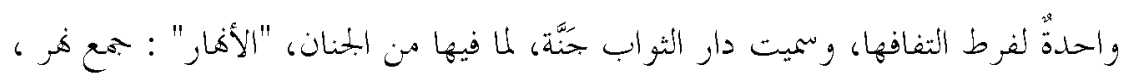

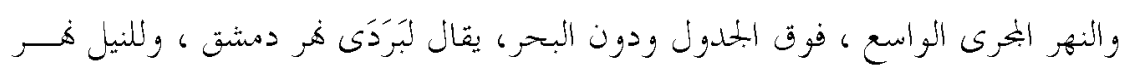




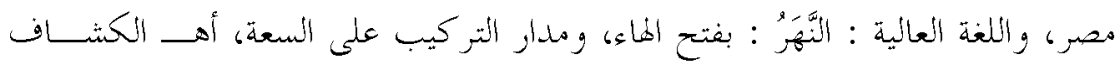

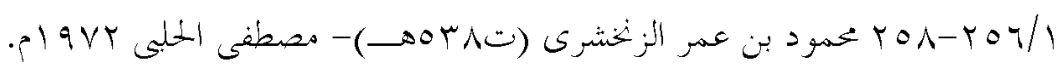

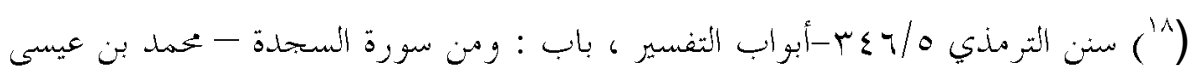

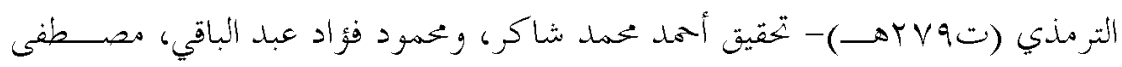
الح .V) V)

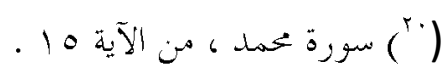

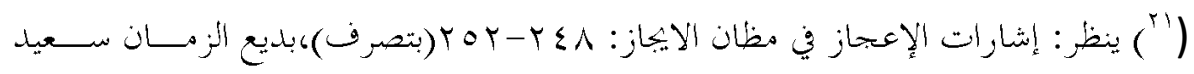

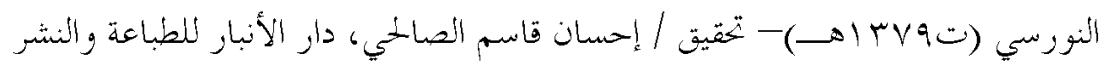

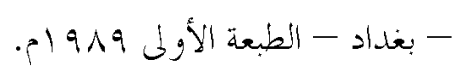

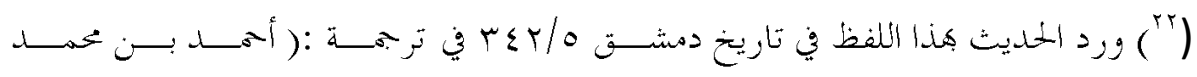

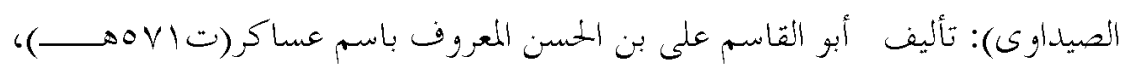

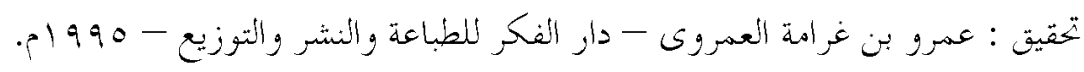

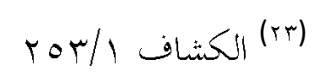

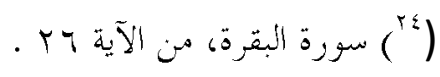

$$
\begin{aligned}
& \text { ( ) } \\
& \text { rON/1 الكشاف (T) }
\end{aligned}
$$

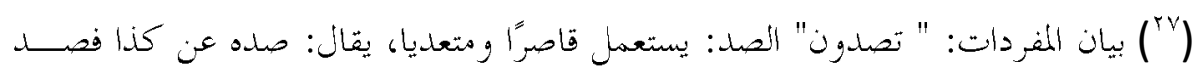

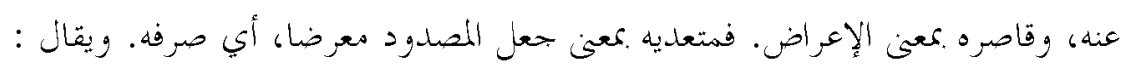

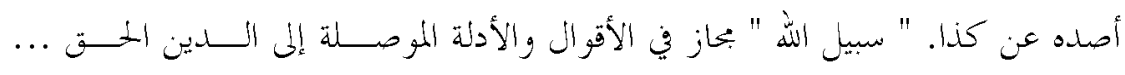

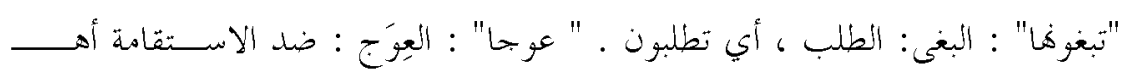

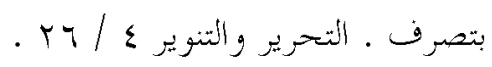

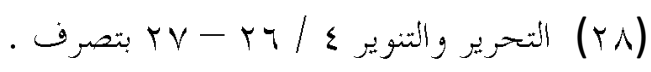

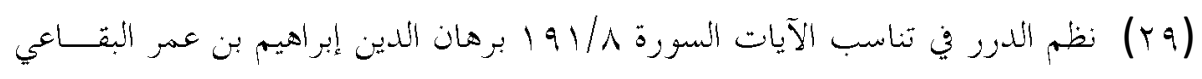

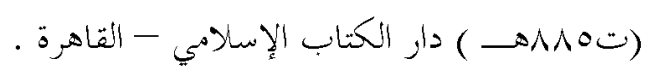




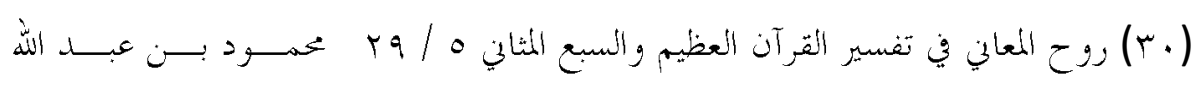

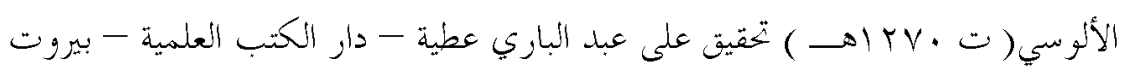

$$
\text { - } \rightarrow 1 \leqslant 10-
$$

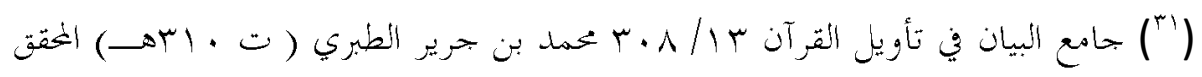

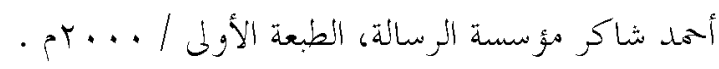

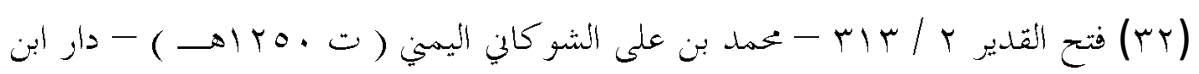

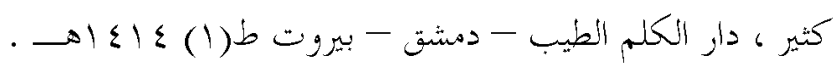

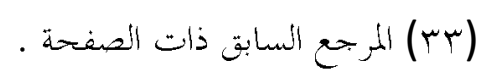

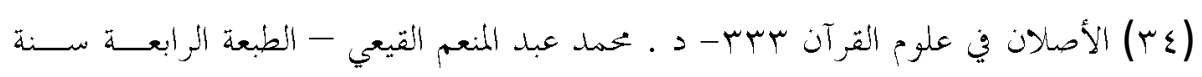
. 1997

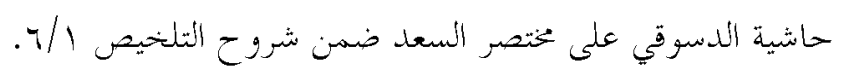

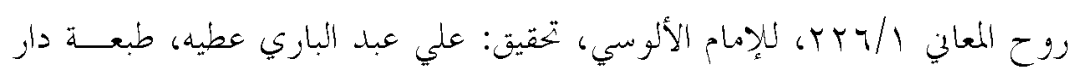

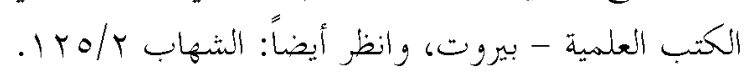

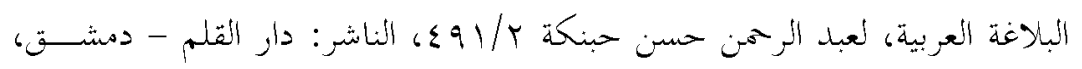

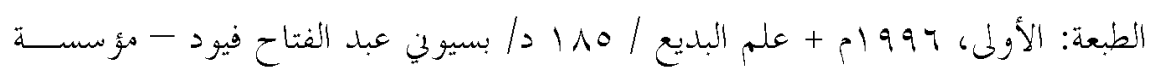

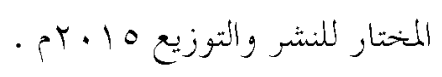

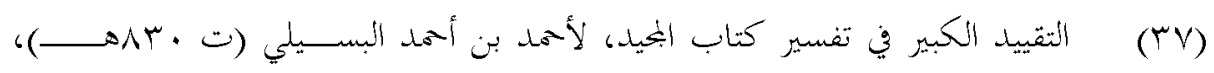

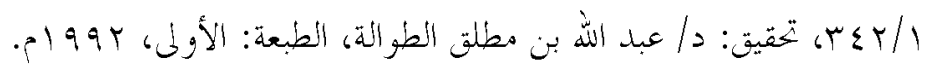

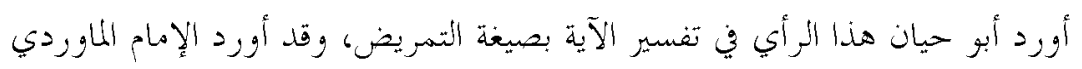
$(\lessdot \wedge)$

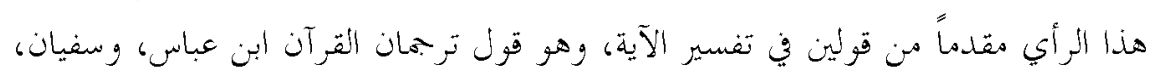

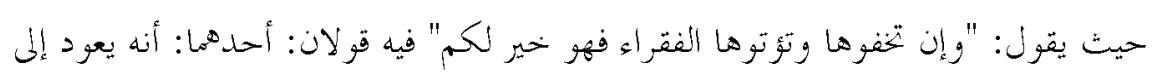

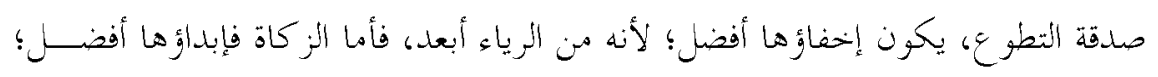

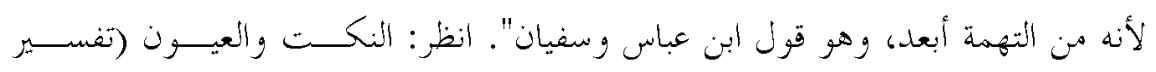

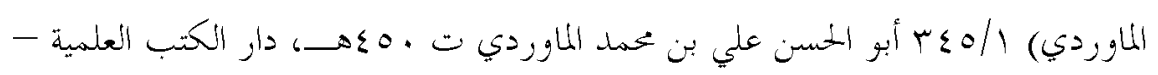
بيروت - لبنان. 


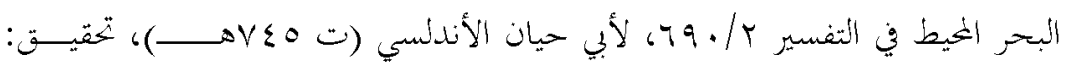

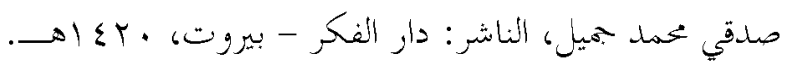

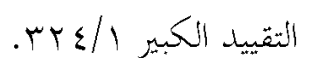

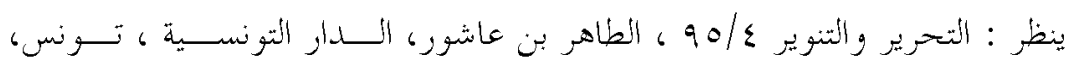

pla

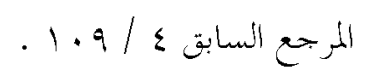

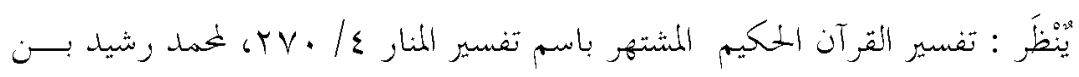

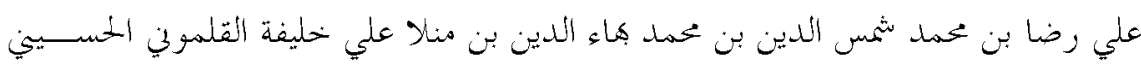

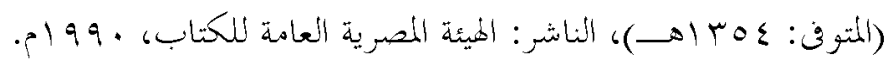

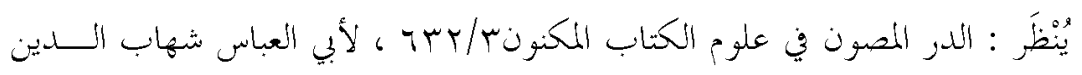

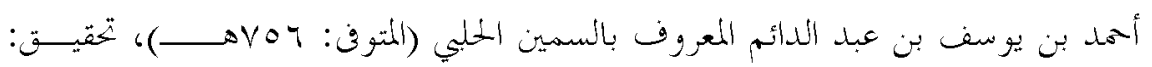

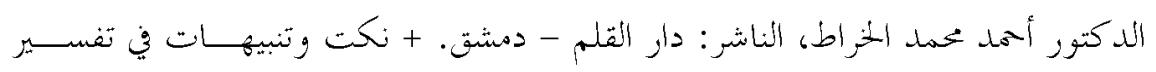

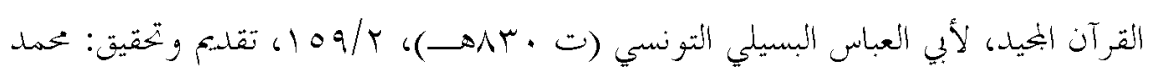

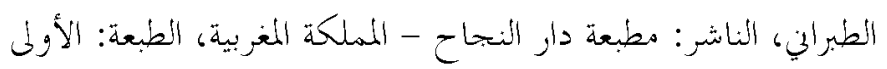

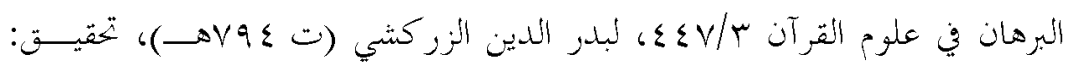

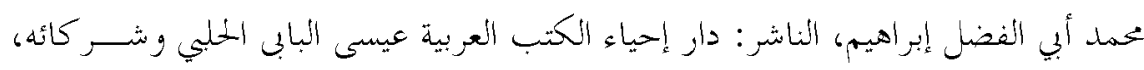

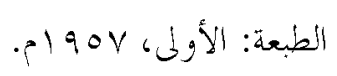

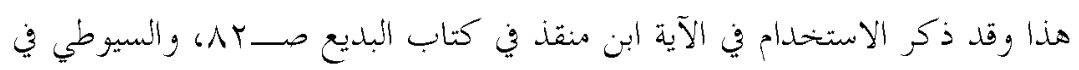

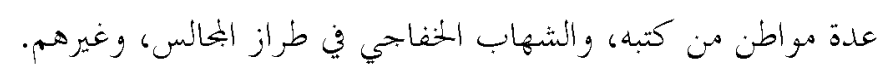

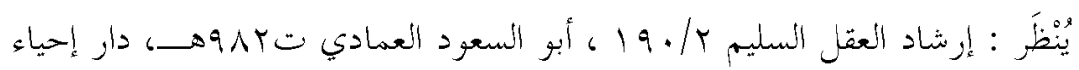

$$
\text { التراث العربي. }
$$

يُنظرَ : عناية القاضي و كفاية الراضي(حاشية الشهاب المُفاجي على تفسير البيضاوي)

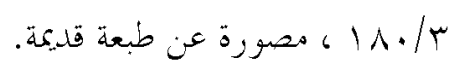

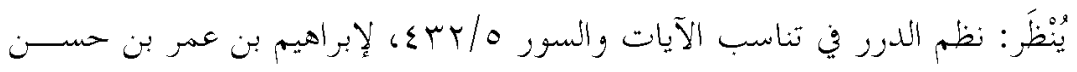

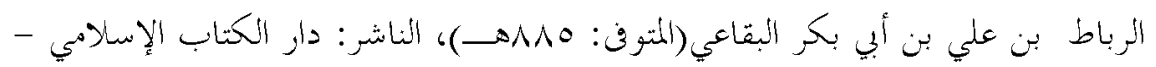
القاهرة. 


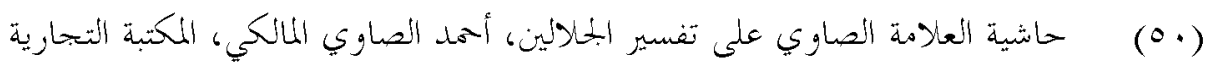

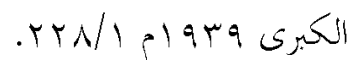

$$
\begin{aligned}
& \text { معترك الأقران }
\end{aligned}
$$

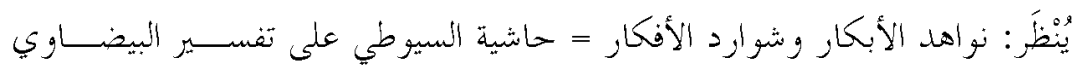

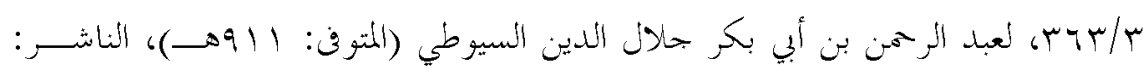

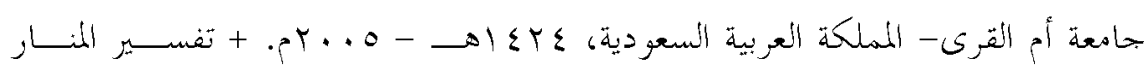

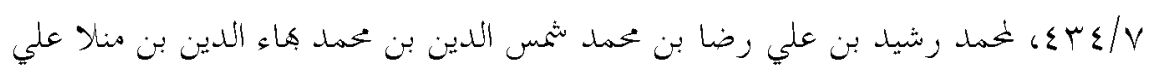

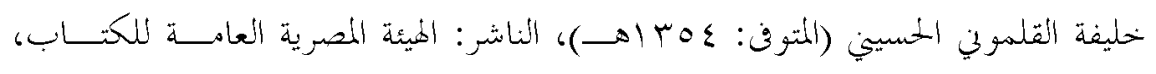

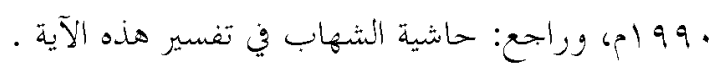

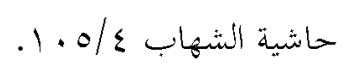

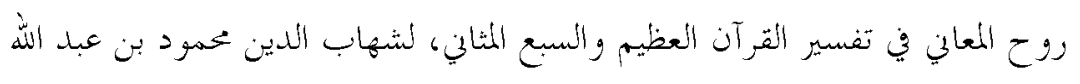

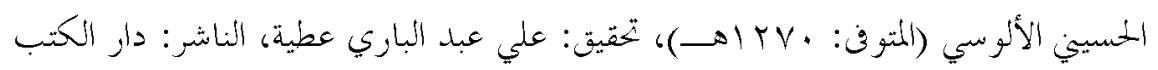

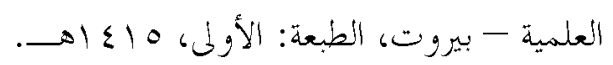

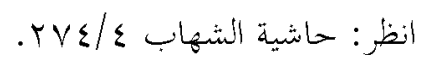

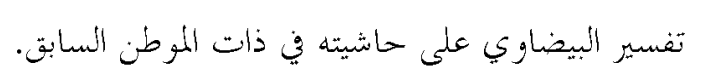

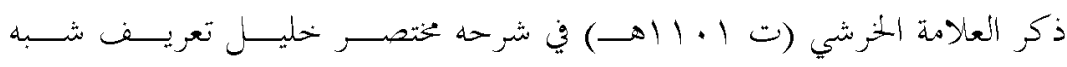

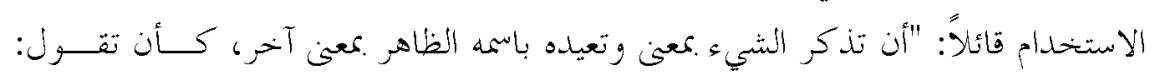

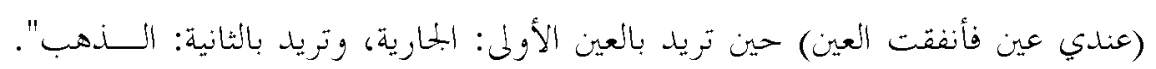

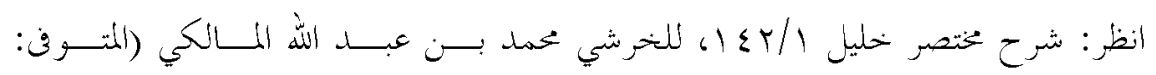

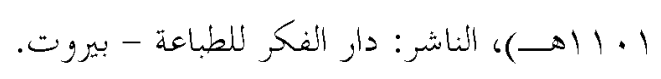

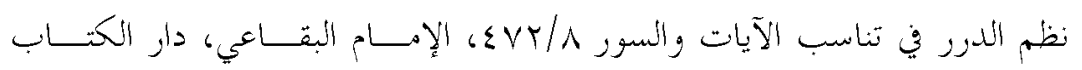

$$
\begin{aligned}
& \text { الإسلامي مصورة عن طبعة الهند. }
\end{aligned}
$$

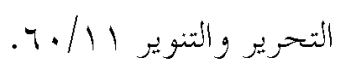

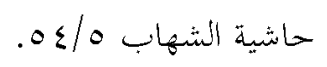

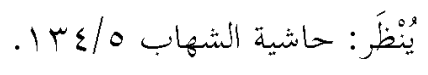

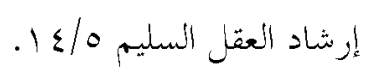




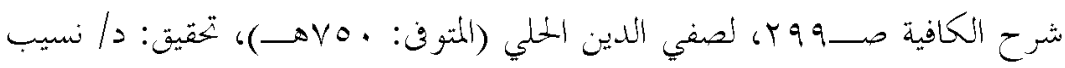

نشاوي، الناشر: دار صادر، الطبعة: الثنانية.

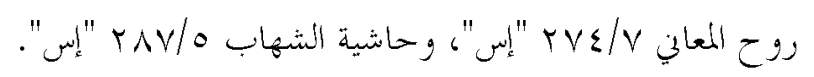

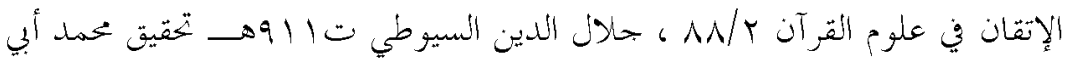

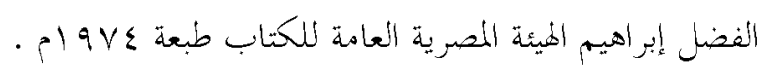

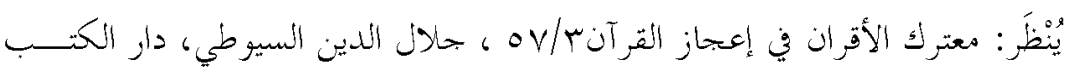

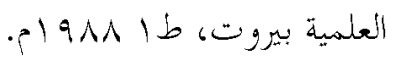

$$
\begin{aligned}
& \text { روح المعان }
\end{aligned}
$$

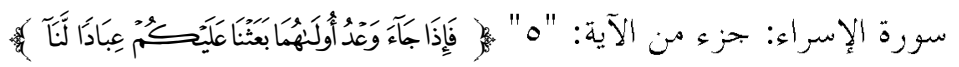

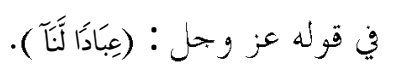

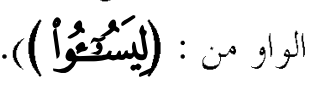

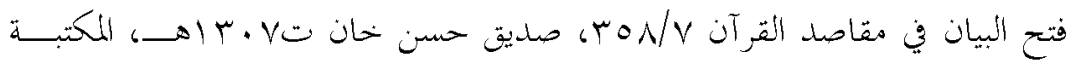

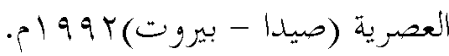

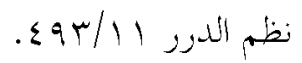

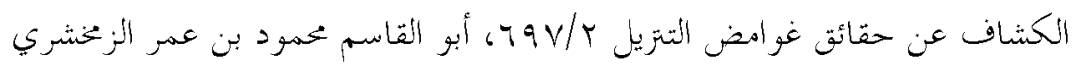

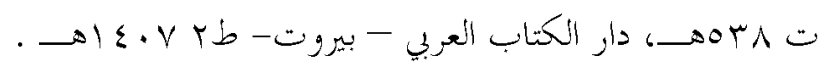

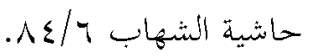

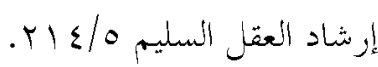

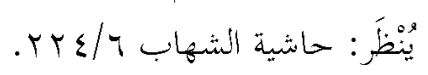

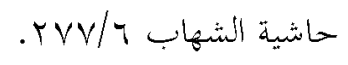

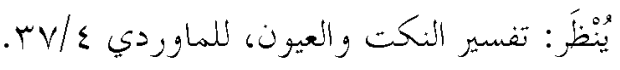

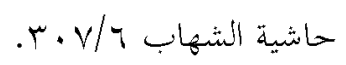

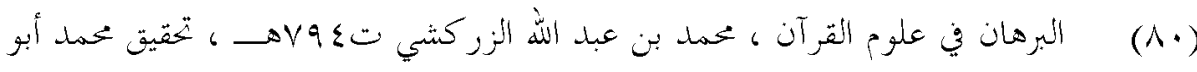

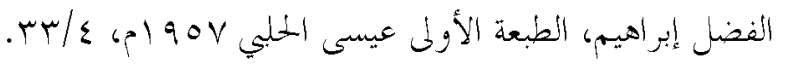

$$
\begin{aligned}
& \text { (Al) }
\end{aligned}
$$

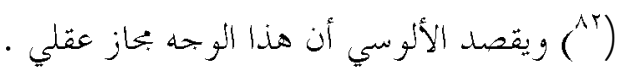




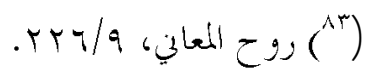

$$
\begin{aligned}
& \text { ( }
\end{aligned}
$$

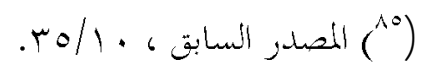

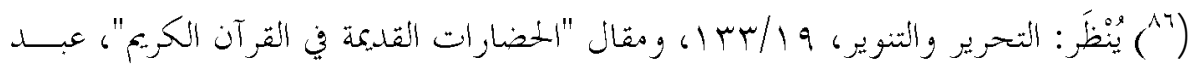

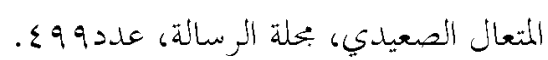

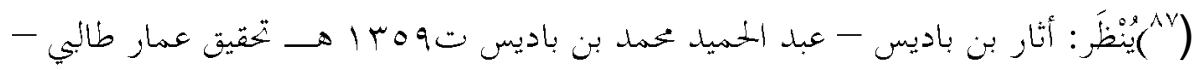

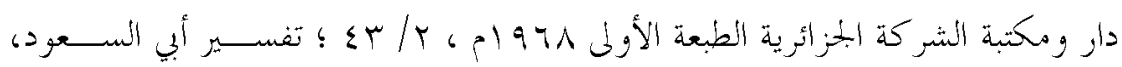

$$
\begin{aligned}
& \text {. TAl/ }
\end{aligned}
$$

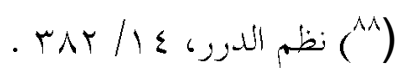

$$
\begin{aligned}
& \text { ( }
\end{aligned}
$$

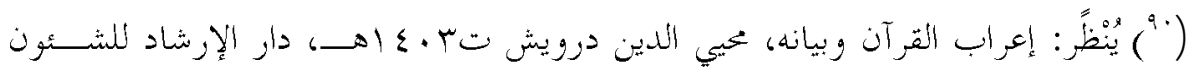

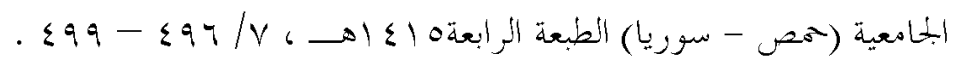

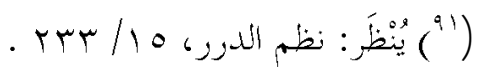

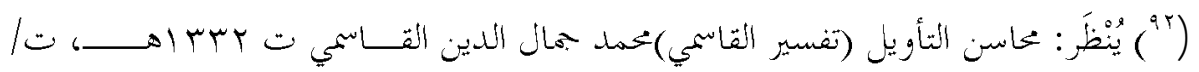

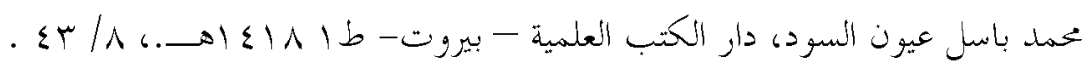

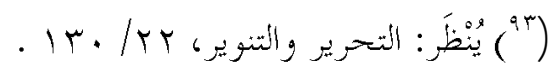

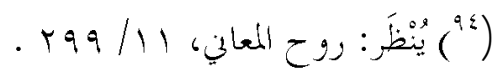

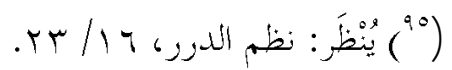

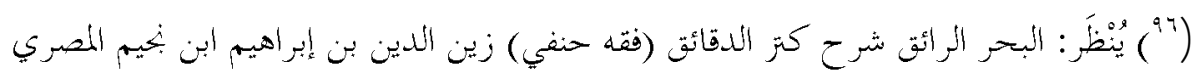

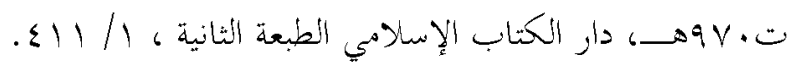

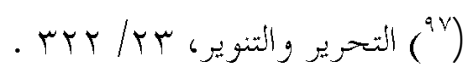

$$
\begin{aligned}
& \text { ( })
\end{aligned}
$$

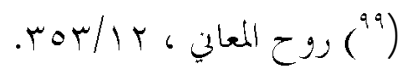

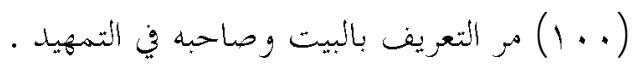

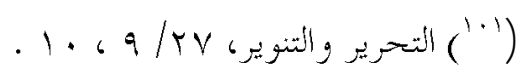

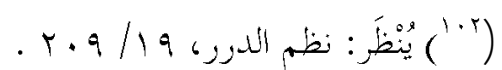




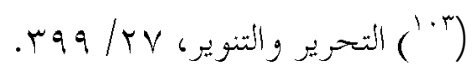

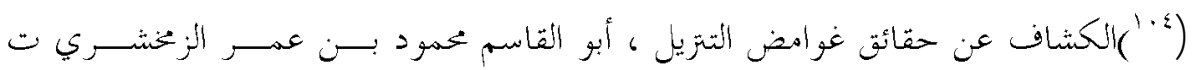

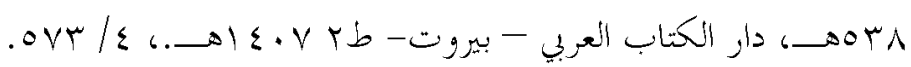

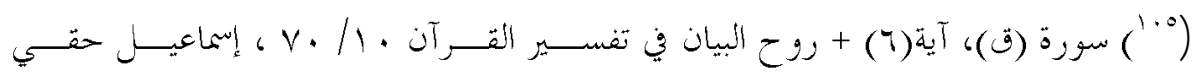

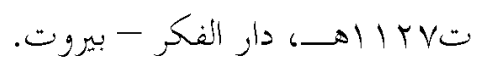

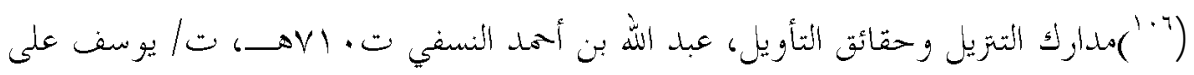

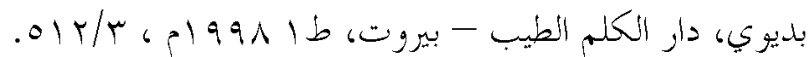

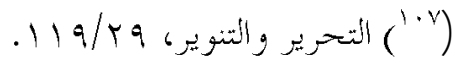

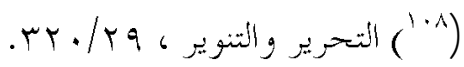

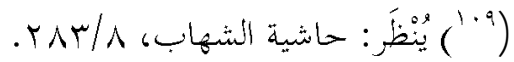

$$
\begin{aligned}
& \text { (") }
\end{aligned}
$$

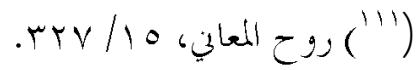

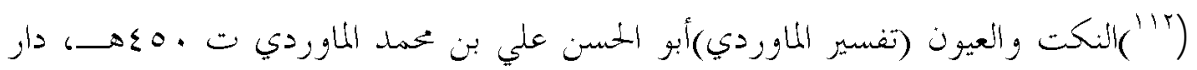

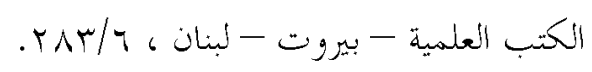

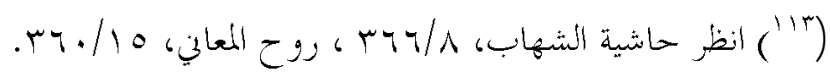

$$
\text { (") }
$$

(110)

$$
\text { (1/7) }
$$

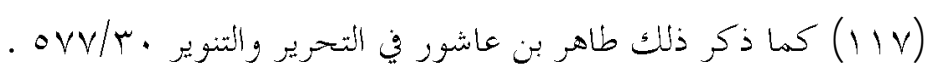

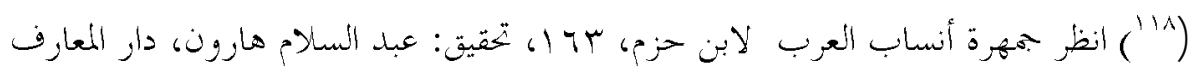

